\title{
TINGKAT PREVALENSI PARASIT Perkinsussp. TERHADAP KERANG DI TELUK JAKARTA
}

\author{
Armen Nainggolan \\ Jurusan Budidaya Perairan, Fakultas Perikanan dan Ilmu Kelautan Universitas Satya Negara Indonesia \\ Jln. Arteri Pondok Indah n0.11 Jakarta 12240 \\ E-mail: tufikan@yahoo.com
}

\begin{abstract}
Perkinsiosisis a disease caused by the protozoan parasite Perkinsus sp. that can infect shellfish, especially bivalve molluscs, in various parts of the world. Molecular identification and prevalence of Perkinsus sp. parasitism in shellfish traded in Jakarta, especially green mussel (Perna viridis), blood cockle (Anadara granosa) and blood clam (Anadara inflata)were collected from TPI Muara Angke, TPI Muara Kamal, TPI Muara Baru and TPI Cilincing. Established from gill and mantle fragment examined with Polymerase Chain Reaction (PCR) test. The primer of Perkinsus genus is PerkITS-85 forward 5 'CCG GAT TTG CTT TGT CCC 3' and PerkITS-750 reverse 5 'ACA TCA CTT GGC CTA ATG ATG 3'. The extraction and amplification reagent used Promega Kit. Results of PCR showed the presence of Perkinsus sp.in blood cockle and blood clam from TPI Muara Angke, TPI Muara Kamal, TPI Muara Baru and TPI Cilincing on the $703 \mathrm{bp}$ of electroforesis product. The highest prevalence of Perkinsus sp. in blood clam (Anadara inflata) located in TPI Muara Angke are $46 \%$ followed by TPI Muara Kamal $34 \%$, TPI Muara Baru $34 \%$ and TPI Cilincing $32 \%$. The highest prevalence of Perkinsus sp. in blood cockle (Anadara granosa) located in TPI Muara Kamal are $50 \%$ followedby TPI Muara Angke $43 \%$, TPI Cilincing $32 \%$ and TPI Muara Baru $26 \%$.
\end{abstract}

Key words: Polymerase Chain Reaction, Anadara granosa, Anadara inflata, Perna viridis, Perkinsus sp.

\section{PENDAHULUAN}

Perkinsiosis adalah penyakit kerang yang disebabkan oleh parasit protozoa pada Perkinsus sp. Perkinsiosis telah ditemukan pada beberapa jenis kerang tiram (oyster), kerang (clam), kerang abalone dan kerang scallop. Insang dan mantel merupakan organ target Perkinsus sp. (Choi \& Park, 2010) dikarenakan berhubungan langsung dengan air laut dan dilihat dari cara kerang-kerangan mengambil makanannya dengan menyaring partikel-partikel yang ada di dalam air laut atau filter feeder (Nontji, 1987).

Pada tahun 2012, hasil tangkapan perikanan meningkat hingga 92.458.055 ton dan hasil tangkapan kerang-kerangan diperkirakan mencapai $3 \%$ (2.889.006 ton). Sekitar $56 \%$ hasil tangkapan kerang-kerangan dunia berasal dari benua Asia, pada umumnya berasal dari China, Jepang dan Vietnam(FAO, 2014). Produksi tiram mencakup $90 \%$ dari produksi kerang-kerangan yang ada di dunia (Choi \& Park, 2010). Faktor lingkungan yang berpengaruh dalam perkembangan parasit Perkinsus sp. adalah suhu dan salinitas yang tinggi. Infeksi ini akan semakin meningkat pada akhir musim kemarau di wilayah estuaria (Soniat, 2012).

Persebaran perkinsiosis berada di daerah perairan pantai seluruh dunia, termasuk lautan Atlantik, laut Mediterania dan lautan Pasifik Selatan. Spesies pertama yang berhasil ditemukan pada Perkinsus sp. berawal dari sebuah penelitian pada tahun 1946 tentang penyebab kematian massal pada tiram di Lousiana (Teluk Meksiko, Amerika Serikat). Akibat dampak ekonomi yang berimbas pada budidaya moluska ini di mana tingkat kematian massal mencapai $50 \%$ pada tiram dewasa, beberapa peneliti bergabung untuk mencari penyebab kematian massal ini. 2 tahun kemudian, John Mackin, Malcolm Owen dan Albert Collier telah menemukan Dermocystidium marinumyang sekarang disebut Perkinsus marinus(Villalba, et al., 2004). Di Australia pada survey dari beberapa penyakit parasit dan beberapa species kerang di Australia Barat Utara terhadap penyakit organisme akuatik ditemukan keberadaan Perkinsus olseni pada kerang dari Anadara trapezia dan banyak jenis molusca lainnya termasuk Tridacna gigas, Tridacna maxima, Tridacna crocea dan Katelysia rhytiphora(Australian Government, 2012). Hal ini dipertegas oleh Carnegie \& Burreson (2009), bahwa Perkinsus marinus menyebabkan kematian massal hingga $97 \%$ pada tahun 2006 - 2008 di wilayah pantai Virginia, Amerika Serikat dengan rincian lebih lengkap dapat dilihat pada Tabel 1 berikut ini:

Kata kunci: Polymerase Chain Reaction, Anadara granosa, Anadara inflata, Perna viridis, Perkinsus sp. 
Tabel 1. Mortalitas dan prevalensi Perkinsus marinus pada kerang di pantai Virginia, Amerika Serikat pada tahun 2006-2008

\begin{tabular}{|c|c|c|c|}
\hline \multirow[t]{2}{*}{ Tanggal } & \multirow[t]{2}{*}{ Mortalitas } & \multicolumn{2}{|l|}{ Perkinsus marinus } \\
\hline & & Infeksi/Total Sampel & Prevalensi \\
\hline 28 April 2006 & $0 \%$ & $0 / 24$ & $0 \%$ \\
\hline 06 Juni 2006 & $1,8 \%$ & $5 / 25$ & $20 \%$ \\
\hline 05 Juli 2006 & $4,4 \%$ & $12 / 25$ & $48 \%$ \\
\hline 02 Agustus 2006 & $62,4 \%$ & $23 / 24$ & $96 \%$ \\
\hline 20 September 2006 & $93,3 \%$ & $16 / 16$ & $100 \%$ \\
\hline 25 April 2007 & $0 \%$ & $1 / 25$ & $4 \%$ \\
\hline 07 Juni 2007 & $2,0 \%$ & $3 / 25$ & $12 \%$ \\
\hline 28 Juni 2007 & $5,1 \%$ & $3 / 25$ & $12 \%$ \\
\hline 09 Agustus 2007 & $55,6 \%$ & $24 / 25$ & $96 \%$ \\
\hline 05 September 2007 & $83,1 \%$ & $24 / 24$ & $100 \%$ \\
\hline 11 Oktober 2007 & $97,4 \%$ & $9 / 9$ & $100 \%$ \\
\hline 30 April 2008 & $0 \%$ & $0 / 25$ & $0 \%$ \\
\hline 04 Juni 2008 & $0,6 \%$ & $3 / 25$ & $12 \%$ \\
\hline 02 Juli 2008 & $3,3 \%$ & $13 / 25$ & $52 \%$ \\
\hline 30 Juli 2008 & $9,7 \%$ & $24 / 25$ & $96 \%$ \\
\hline 05 September 2008 & $72,5 \%$ & $25 / 25$ & $100 \%$ \\
\hline 07 Oktober 2008 & $88,3 \%$ & $25 / 25$ & $100 \%$ \\
\hline
\end{tabular}

Sumber : Carnegie \& Burreson, 2009

BerdasarkanKeputusan Menteri Kelautan dan Perikanan Nomor 26/KEPMEN-KP/2013 bahwa Perkinsus marinus dan Perkinsus olseni merupakanHama dan Penyakit Ikan Karantina golongan I dimana penyakit ini tidak dapat disuci hamakan atau disembuhkan dari media pembawanya karena teknologi perlakuan belum dikuasai dan wilayah persebarannya hanya ada di Jawa Barat, namun belum dilakukan penelitian untuk wilayah lainnya di Indonesia (Kementerian Kelautan dan Perikanan, 2013). Perdagangan yang ada di DKI Jakarta perlu di awasi dan dilakukan monitoring penyakit Perkinsiosis ini untuk mencegah masuk dan tersebarnya dari wilayah yang endemik. Di wilayah DKI Jakarta perdagangan kerang paling utama ada di Tempat Pelelangan Ikan (TPI) Kamal Muara, Tempat Pelelangan Ikan (TPI) Muara Angke. Tempat Pelelangan Ikan (TPI) Muara Baru dan Tempat Pelelangan Ikan (TPI) Cilincing. Komoditi yang dilakukan penangkapan dan dipasarkan secara luas antara lain kerang darah (Anadara granosa), kerang hijau (Perna viridis) dan kerang bulu (Anadara inflata). Pada data statistik FAO tahun 2012, jumlah penangkapan kerang darah di Indonesia mencapai 43,177 ton, kerang hijau 3,353 ton dan kerang bulu 1467 ton (FAO, 2014) . Dilihat dari pola penyebaran distribusi penyakit parasit Perkinsus sp. di dunia, tidak menutup kemungkinan perairan di Indonesia khususnya di wilayah perdagangan kerang di DKI Jakarta telah terjangkit oleh parasit jenis ini.Hal inilah yang melatarbelakangi penulis untuk melakukan penelitian tentang identifikasi dan prevalensi penyakit Perkinsiosis pada berbagai jenis kerang yang diperdagangkan di wilayah DKI Jakarta, khususnya pada kerang darah, kerang bulu dan kerang hijau.

\section{MATERI DAN METODE}

Kegiatan penelitian dilaksanakan pada bulan Juni-Juli 2014 dengan lokasi daerah perdagangan kerang di TPI Pelabuhan Muara Angke, TPI Pelabuhan Muara Baru, TPI Cilincing, dan TPI Muara Kamal. Pengujian berupa pemeriksaan parasit Perkinsus sp. dari sampel kerang darah, kerang hijau, dan kerang bulu secara biologi molekuler bertempat di Laboratorium Balai Karantina Ikan, Pengendalian Mutu dan Keamanan Hasil Perikanan Kelas I Jakarta II dengan alamat Jalan Swasembada Timur XIII No. 64, Kelurahan Kebon Bawang, Kecamatan Tanjung Priok, Kotamadya Jakarta Utara, DKI Jakarta. Sampel yang digunakan dalam penelitian adalah kerang darah, kerang hijau, dan kerang bulu hidup dengan organ target insang dan mantel. Setiap ekor sampel kerang uji berukuran panjang rerata $5 \mathrm{~cm}$ dan tinggi $2 \mathrm{~cm}$, dengan asumsi prevalensi $10 \%$ berdasarkan Amos (1985). Metode yang digunakan untuk mengambil sampel kerang yang diduga terinfeksi Perkinsus sp. adalah menggunakan sampel acak berkelompok (cluster random sampling). Cluster random sampling adalah pengambilan sampel dilakukan terhadap sampling unit, dimana sampling unitnya terdiri dari 
beberapa kelompok (cluster).Dalam penelitian ini yang menjadi cluster adalah lokasi perdagangan kerang di Jakarta, sedangkan individu adalah kerang uji. Pada setiap lokasi pengambilan sampel dilakukan secara acak sebanyak 30 ekor kerang uji tanpa membedakan jenisnya dengan 3 kali ulangan dengan target organ berupa insang dan mantel. 3 kali ulangan artinya pengambilan sampel dilakukan selama 3 hari. Jumlah sampel yang akan diperoleh adalah sebanyak 90 kerang uji pada setiap lokasi, sehingga total sampel yang diperoleh pada 4 lokasi adalah 360 ekor kerang uji

Deteksi Perkinsus sp. secara molekuler dilakukan dengan uji PCR menggunakan bahan-bahan Nucleus Lysis Solution (Promega), RNase Solution (Promega), Protein Precipitation Solution (Promega), Isopropanol, Alkohol 70\%, DNA Rehydration Solution (Promega), Go Taq® Green Master Mix 2X PCR (Promega), Nuclease Free Water (Promega), Primer spesifik Genus Perkinsus sp. (Audemard, et al., 2004)PerkITS-85 forward 5' CCG CTT TGT TTG GAT CCC 3', PerkITS-750 reverse 5' ACA TCA GGC CTT CTA ATG ATG 3', Bovine Serum Albumin Acetylated (Promega), Agarosa 1,5 \%, TAE Buffer 1X \% (Qiagen), 100 bp DNA Ladder (Gene RulerTM Fermentas), Sybr®Green (Lonza), Aquades, Parafilm. Alat yang digunakan dalam penelitian ini antara lain piranti standar laboratoriumbiologi molekuler, antara lainsebagai berikutMikropipet P10, P100, P200 dan P1000, Rak mikropipet, Mikrotube 1,5 mL, Mikrotube 0,2 mL, Rak Mikrotube 1,5 mL, Rak mikrotube 0,2 mL, Mikrotip P10, Mikrotip P 200, Mikrotip P 1000, Vortex, Pestle, Dissecting set, Refrigerated Microcentrifuge, Thermal Cycler, Dry Block Heating Thermostat, Microwave, Elektroforesis, UVI Gel Documentation.

\section{METODE PENELITIAN}

Metode penelitian yang dilakukan adalah dengan menggunakan metode deskriptif yang bertujuan untuk mendeskripsikan secara sistematis, faktual dan akurat terhadap suatu populasi atau daerah tertentu, mengenai sifat atau faktor tertentu (Sudjana, 2002). Penelitian ini menggunakan tahapan-tahapan analisa sebagai berikut: buka cangkang kerang secara perlahan dengan cara menyisipkan pisau pada bagian anterior cangkang lalu potong bagian aduktor, ambil sample bagian insang dan mantel sebanyak 10-20 mg, lakukan tahapan proses ekstraksi DNA yang bertujuan untuk memisahkan DNA dari bahan lain seperti protein, lemak, dan karbohidrat, DNA yang sudah diekstraksi kemudian dilakukan tahapan amplifikasi yang bertujuan untuk memungkinkan adanya perbanyakan DNA antara dua primer, hanya di dalam tabung reaksi, tanpa perlu memasukkannya ke dalam sel (in vivo), DNA yang sudah di amplifikasi akan dilakukan proses elektroforesis yang bertujuan untuk untuk memisahkan sampel DNA berdasarkan atas ukuran (berat molekul) dan struktur fisik molekulnya. Molekul DNA akan terlihat dengan jelas dan berpendar berupa garis putih /band pada alat dokumentasi.

\section{ANALISA DATA}

Data hasil identifikasi parasit Perkinsus sp. pada kerang menggunakan uji PCR akan dianalisa secara deskriptif. Paramater yang akan dianalisa adalahgejala klinis pada kerang uji, perhitungan prevalensi Perkinsus sp. pada setiap lokasi, presentase keberadaan Perkinsus sp.pada organ insang dan mantel, presentase kerang yang terinfeksi pada organ insang, mantel atau insang dan mantel, kehadiran pita DNA Perkinsus sp. pada organ mantel dan insang di dokumentasi foto dan dibandingkan dengan kontrol positif Perkinsus sp.

\section{Hasil}

\section{HASIL DAN PEMBAHASAN}

Selama penelitian diperoleh sampel kerang uji sebanyak 360 ekor pada 4 lokasi dengan rincian hasil pada Tabel 2. 
Tabel 2. Hasil Pemeriksaan PCR terhadap Perkinsus sp. pada Kerang Uji Selama Penelitian

\begin{tabular}{|c|c|c|c|c|}
\hline Lokasi & Kerang Bulu & Kerang Darah & Kerang Hijau & Jumlah Total \\
\hline TPI Muara Angke & 26 & 32 & 32 & 90 \\
\hline Terinfeksi & 12 & 14 & 0 & 26 \\
\hline Tidak Terinfeksi & 14 & 18 & 32 & 64 \\
\hline TPI Kamal Muara & 29 & 28 & 33 & 90 \\
\hline Terinfeksi & 10 & 14 & 0 & 23 \\
\hline Tidak Terinfeksi & 19 & 14 & 33 & 67 \\
\hline TPI Muara Baru & 29 & 31 & 30 & 90 \\
\hline Terinfeksi & 10 & 8 & 0 & 18 \\
\hline Tidak Terinfeksi & 19 & 23 & 30 & 72 \\
\hline TPI Cilincing & 25 & 38 & 27 & 90 \\
\hline Terinfeksi & 8 & 12 & 0 & 20 \\
\hline Tidak Terinfeksi & 17 & 26 & 27 & 70 \\
\hline "Jumlah Total & 109 & 129 & 122 & 360 \\
\hline Terinfeksi & 40 & 48 & 0 & 88 \\
\hline Tidak Terinfeksi & 69 & 81 & 122 & 272 \\
\hline
\end{tabular}

Sumber: Data Primer, 2014

\section{Kerang Bulu (Anadara inflata)}

Kerang bulu (Anadara inflata) yang diperoleh selama penelitian adalah berjumlah 26 ekor di TPI Muara Angke, 29 ekor di TPI Kamal Muara, 29 ekor di TPI Muara Baru, 25 ekor di TPI Cilincing. Kerang bulu yang terinfeksi Perkinsus sp. dengan jumlah terinfeksi terbanyak terdapat di TPI Muara Angke, yaitu sebanyak 12 ekor, diikuti oleh TPI Muara Baru dan TPI Kamal Muara sebanyak 10 ekor, dan TPI Cilincing sebanyak 8 ekor (Tabel 2).

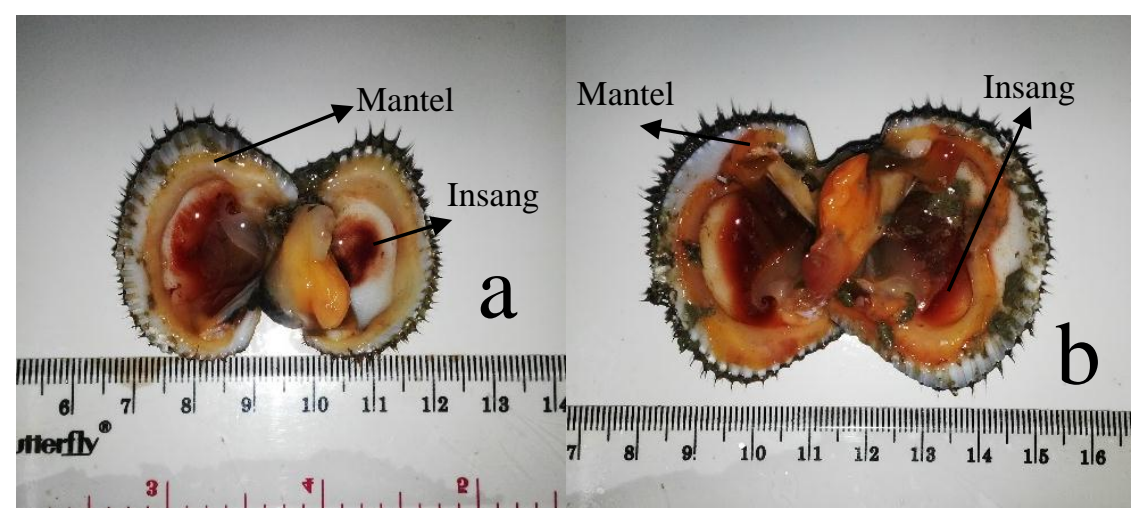

Gambar 1. (a) Kerang yang terinfeksi Perkinsus sp., (b) Kerang yang tidak terinfeksi Perkinsus sp. (Data Primer, 2014) 
Gejala klinis kerang bulu (Anadara inflata) yang terinfeksi Perkinsus sp. pada Gambar 1a menunjukkan tanda-tanda seperti, mantel mengkerut serta berwarna pucat dan insang mengalami kerusakan jaringan berupa hilangnya beberapa lembaran insang, sedangkan pada kerang bulu yang tidak terinfeksi memiliki mantel dan insang yang cerah (Gambar 1b).

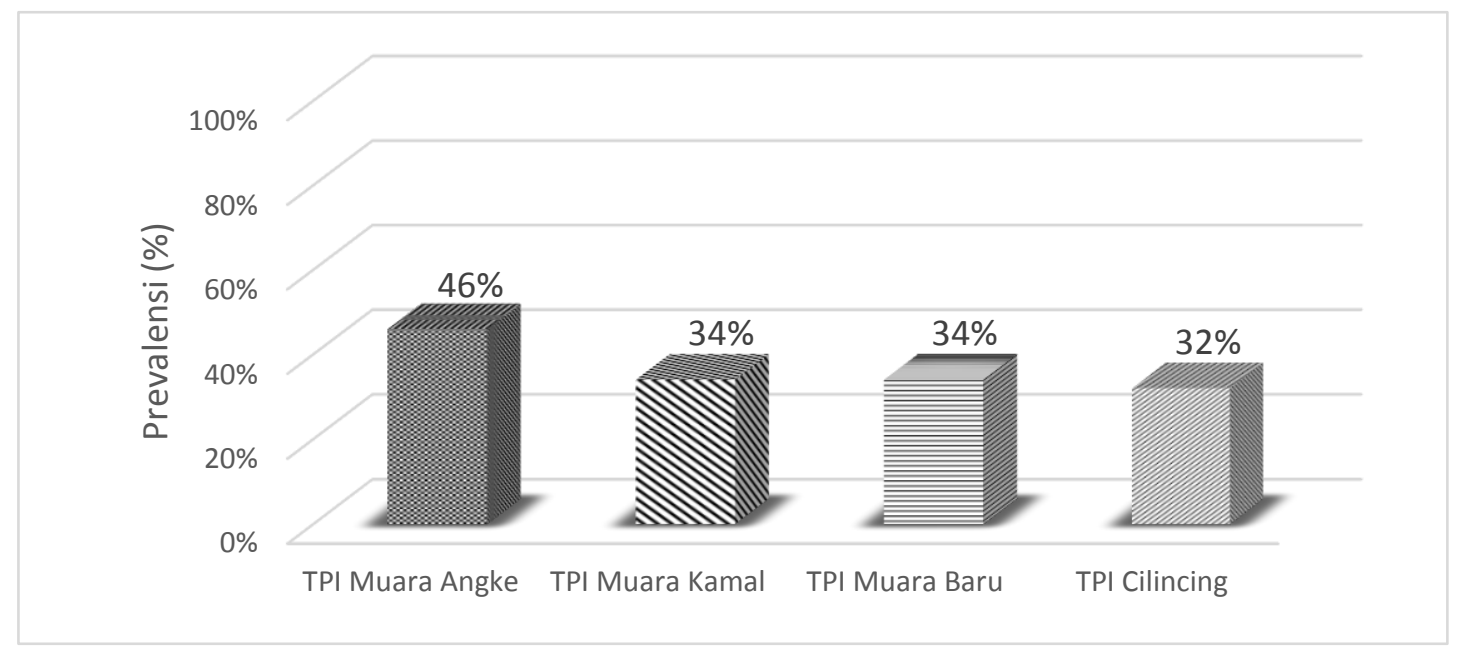

Gambar 2. Prevalensi Perkinsus sp. pada Kerang Bulu Selama Penelitian (Data Primer, 2014)

Kerang bulu yang memiliki prevalensi Perkinsus sp. tertinggi pada lokasi TPI Muara Angke, yaitu sebesar $46 \%$, diikuti oleh TPI Muara Baru dan TPI Kamal Muara dengan prevalensi sebesar $34 \%$ dan TPI Cilincing sebesar $31 \%$ (Gambar 2). Adanya perbedaan prevalensi pada setiap lokasi dikarenakan faktor yang mempengaruhinya, yaitu perbedaan kondisi kualitas air pada tiap lokasi penangkapan kerang bulu, penyebaran Perkinsus sp. yang menyerang kerang bulu memiliki daya tahan kerang yang berbeda, sehingga kerang yang dalam kondisi sakit akan mudah terserang. Masa inkubasi Perkinsus sp. untuk infeksi kerang bulu pada setiap lokasi memiliki masa yang berbeda juga.

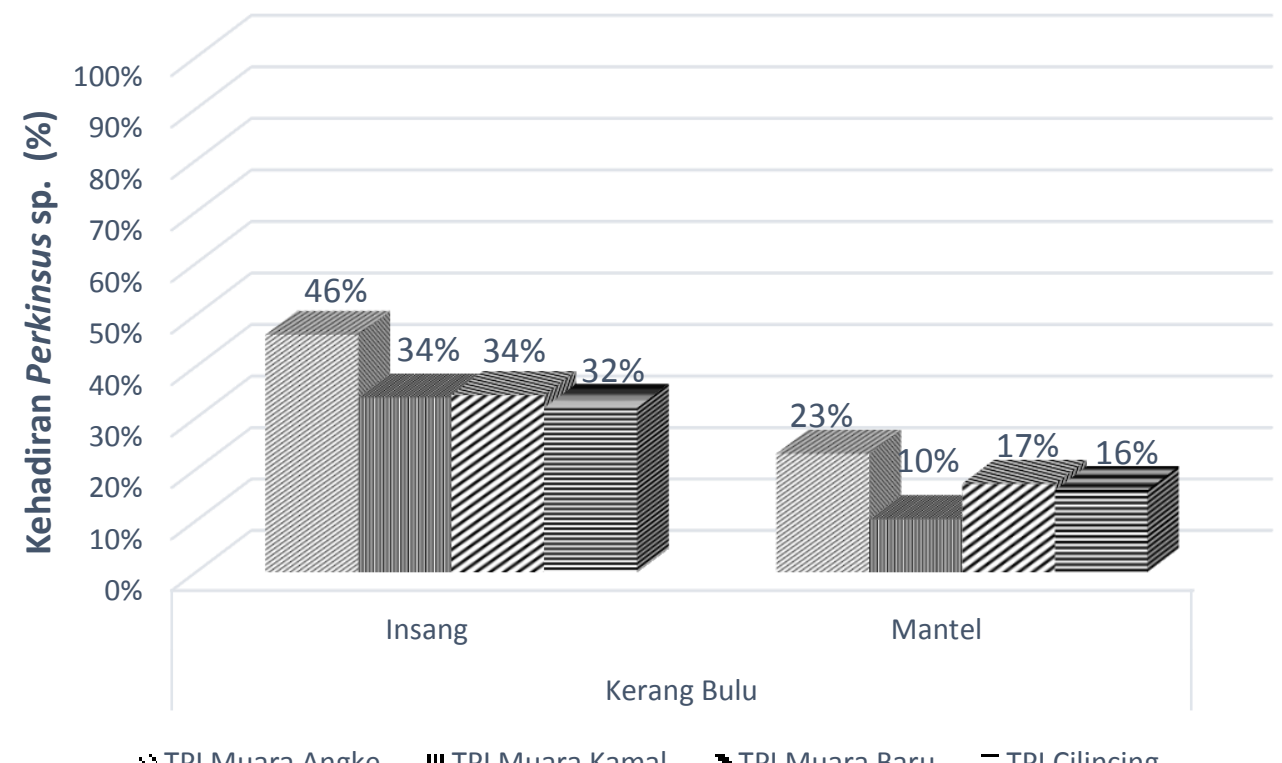

Gambar 3. Persentase Kehadiran Perkinsus sp. di Kerang Bulu pada Organ Insang dan Mantel (Data Primer, 2014). 
Persentase kehadiran Perkinsus sp. pada organ insang tertinggi di TPI Muara Angke sebesar 46\%, diikuti TPI Muara Baru dan TPI Kamal Muara sebesar 34\%, TPI Cilincing 32\%. Persentase kehadiran Perkinsus sp. pada mantel paling tinggi pada TPI Muara Angke sebesar 23\% diikuti TPI Muara Baru sebesar 17\%, TPI Cilincing sebesar $16 \%$ dan TPI Kamal Muara sebesar 10\% (Gambar 3). Persentase insanglebih tinggi dari persentase pada mante dikarenakan insang merupakan target utamaseranganPerkinsus sp. karena sifat kerang mengambil makanannya dengan cara filter feeder sehingga air selalu masuk dan tersaring melalui insang.

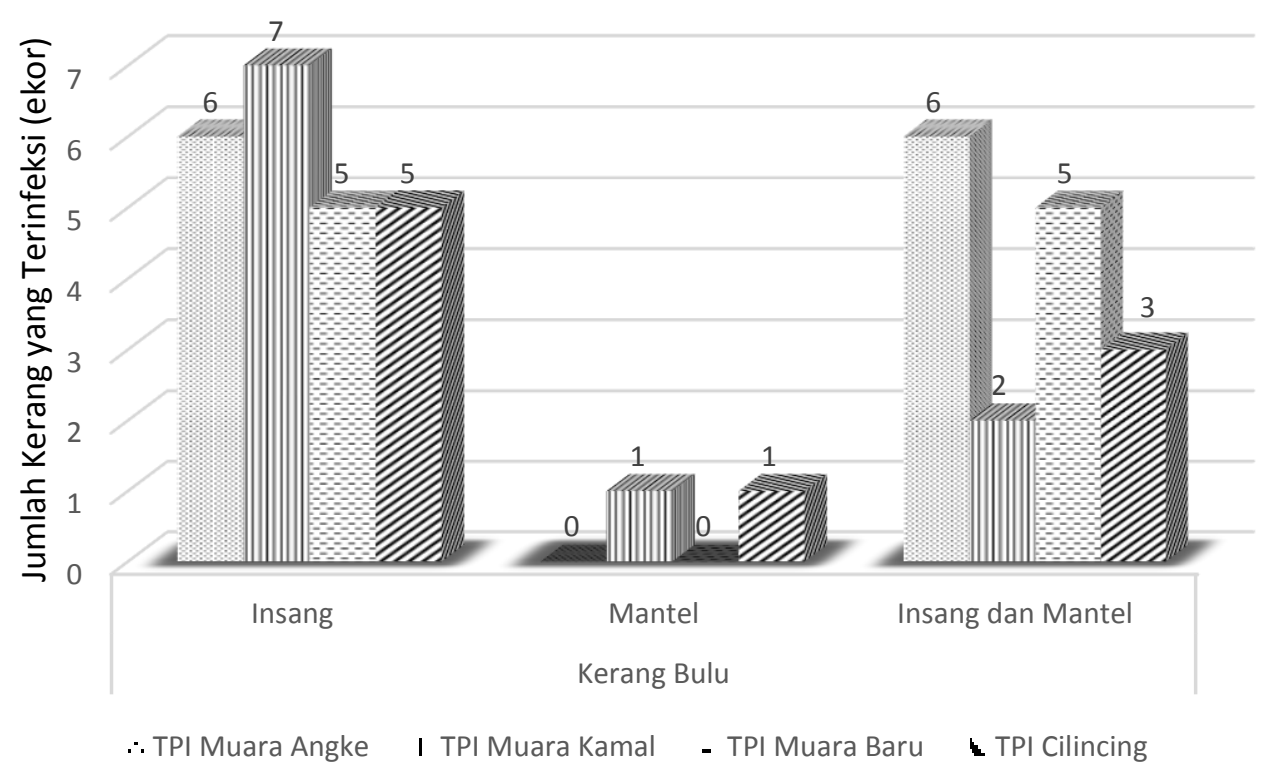

Gambar 4. Hasil Pemeriksaan Kerang Bulu yang Positif Perkinsus sp. Menggunakan PCR pada Organ Insang dan Mantel (dalam ekor) (Data Primer, 2014)

Kerang bulu yang terinfeksi Perkinsus sp. hanya di bagian insang paling banyak terdapat di TPI Kamal Muara sebanyak 7 ekor diikuti oleh TPI Muara Angke sebanyak 6 ekor TPI Cilincing sebanyak 5 ekor dan TPI Kamal Muara sebanyak 5 ekor. Kerang bulu yang hanya terinfeksi hanya pada organ mantel terdapat di TPI Kamal Muara dan TPI Cilincing saja, yaitu masing-masing sebanyak 1 ekor. Hal ini dikarenakan tingkat sensitivitas dari metode PCR yang mampu mengidentikasi secara akurat di mana kerang yang terinfeksi pada mantel saja mengindikasikan bahwa Perkinsus sp. ini baru memasuki organ mantel dan belum sampai pada organ insang, sehingga pencegahan bisa dilakukan supaya tidak terjadi penyebaran ke organ yang lain. Kerang bulu yang terinfeksi di bagian insang dan mantel paling banyak terdapat di TPI Muara Angke sebanyak 6 ekor, diikuti oleh TPI Muara Baru sebanyak 5 ekor, TPI Cilincing sebanyak 3 ekor dan TPI Kamal Muara sebanyak 2 ekor (Gambar 4).

\section{Kerang Darah (Anadara granosa)}

Kerang darah (Anadara granosa) yang diperoleh selama penelitian adalah berjumlah 32 ekor di TPI Muara Angke, 28 ekor di TPI Kamal Muara, 31 ekor di TPI Muara Baru, 38 ekor di TPI Cilincing. Kerang darah yang terinfeksi Perkinsus sp. dengan jumlah terinfeksi terbanyak terdapat di TPI Muara Angke dan TPI Kamal Muara masing-masing sebanyak 14 ekor, diikuti oleh TPI Cilincing sebanyak 12 ekor dan TPI Muara Baru sebanyak 8 ekor (Tabel 2). 


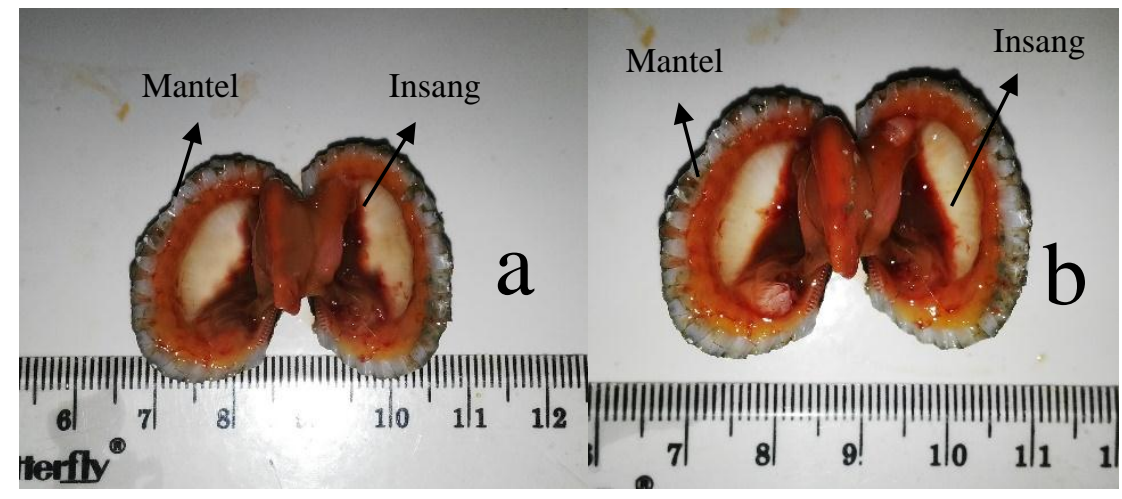

Gambar 5.(a) Kerang yang terinfeksi Perkinsus sp. , (b) Kerang yang tidak terinfeksi Perkinsus sp. (Data Primer, 2014)

Gejala klinis kerang darah (Anadara granosa) yang terinfeksi Perkinsus sp. pada Gambar 5a menunjukkan tanda-tanda seperti insang yang geripis dan mantel yang berwarna pucat, sedangkan pada kerang darah yang tidak terinfeksi memiliki mantel dan insang yang cerah serta dalam kondisi utuh (Gambar $5 b)$.

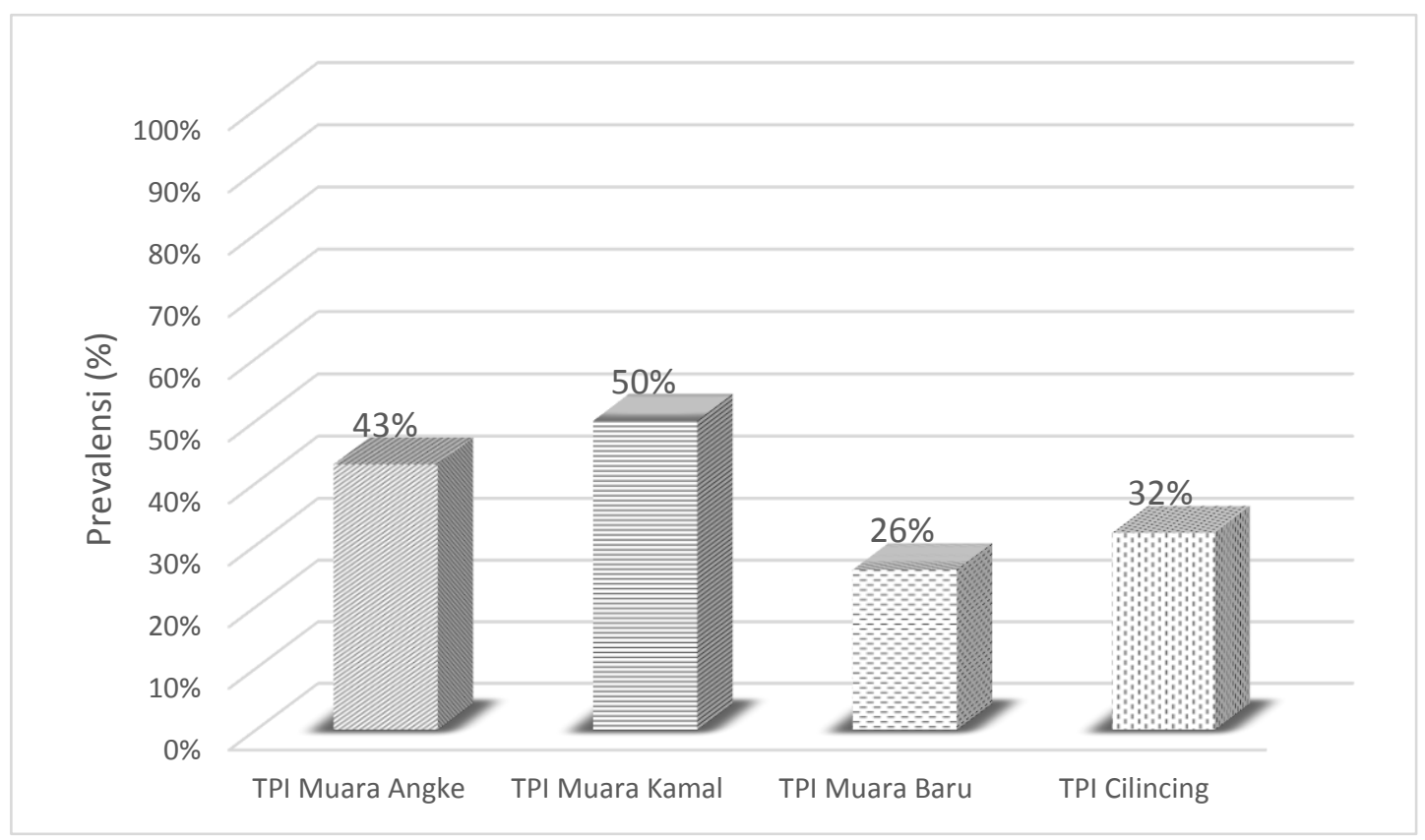

Gambar 6. Prevalensi Perkinsus sp. pada Kerang Darah Selama Penelitian (Data Primer, 2014)

Kerang darah yang memiliki prevalensi Perkinsus sp. tertinggi pada lokasi TPI Kamal Muara, yaitu sebesar $50 \%$, diikuti oleh TPI Muara Angke dengan prevalensi sebesar $43 \%$, TPI Cilincing sebesar $32 \%$ dan TPI Muara Baru sebesar $26 \%$ (Gambar 6 ). Adanya perbedaan prevalensi pada setiap lokasi dikarenakan faktor yang mempengaruhinya, yaitu perbedaan kondisi kualitas air pada tiap lokasi penangkapan kerang bulu, penyebaran Perkinsus sp. yang menyerang kerang darah memiliki daya tahan kerang yang berbeda, sehingga kerang yang dalam kondisi sakit akan mudah terserang. Masa inkubasi Perkinsus sp. untuk infeksi kerang darah pada setiap lokasi memiliki masa yang berbeda juga. 


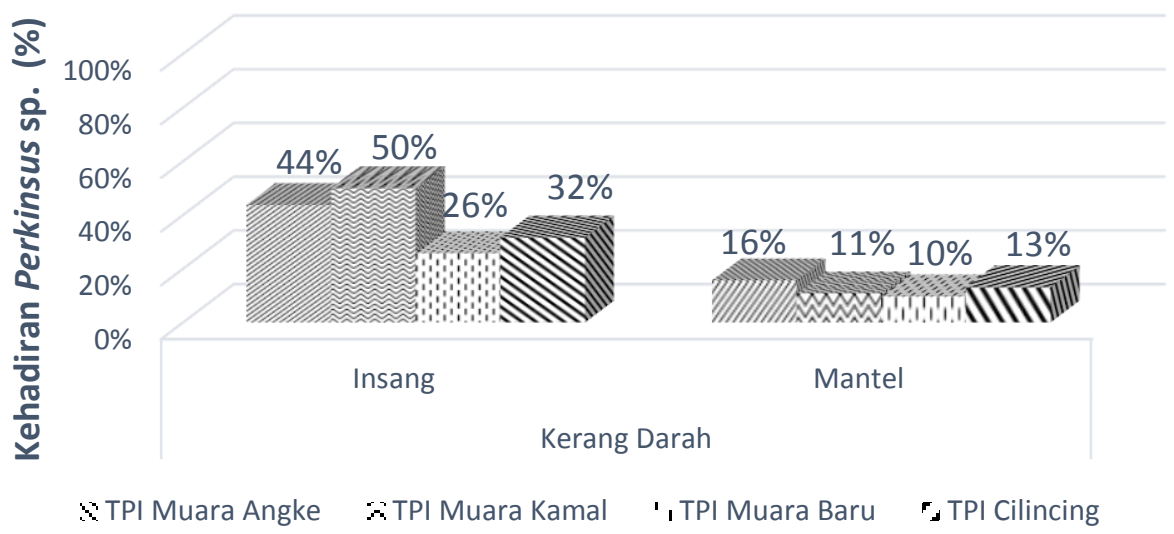

Gambar 7. Persentase Kehadiran Perkinsus sp. di Kerang Darah pada Organ Insang dan Mantel (Data Primer, 2014)

Persentase Perkinsus sp. pada organ insang tertinggi di TPI Kamal Muara sebesar 50\% diikuti TPI Muara Angke sebesar 44\%, TPI Cilincing sebesar 32\% dan TPI Muara Baru sebesar 26\%. Persentase Perkinsus sp. Pada mantel tertinggi pada TPI Muara Angke sebesar 16\%, diikuti TPI Cilincing sebesar 13\%, TPI Kamal Muara sebesar 11\% dan TPI Muara Baru sebesar 10\% (Gambar 7). Persentase insanglebih tinggi dari persentase pada mante dikarenakan insang merupakan target utamaseranganPerkinsus sp. karena sifat kerang mengambil makanannya dengan cara filter feeder sehingga air selalu masuk dan tersaring melalui insang.

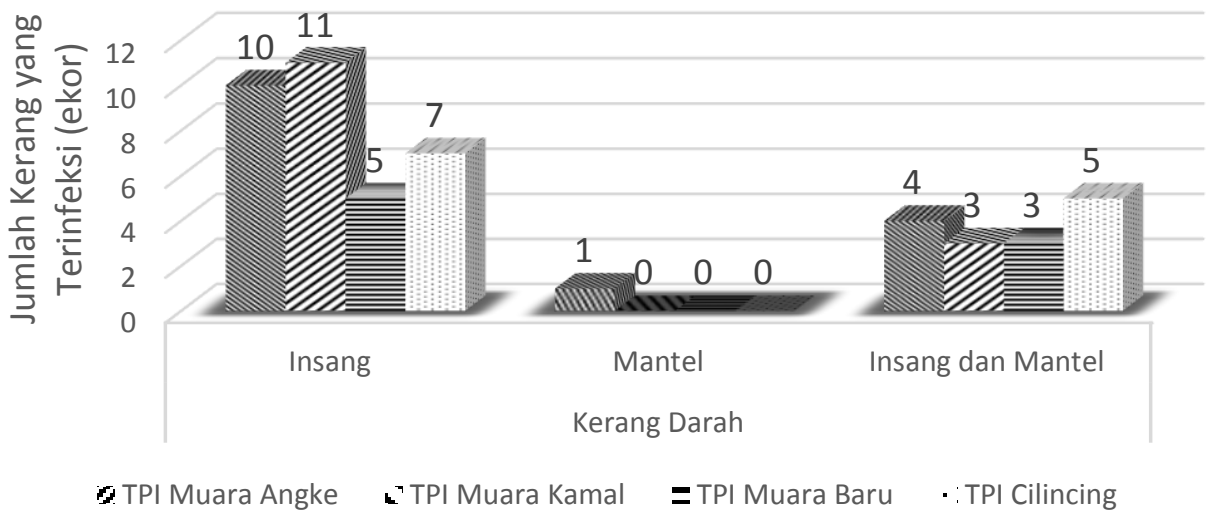

Gambar 8. Hasil Pemeriksaan Kerang Darah yang Positif Perkinsus sp. Menggunakan PCR pada Organ Insang dan Mantel (dalam ekor) (Data Primer, 2014)

Kerang darah yang terinfeksi Perkinsus sp. hanya di bagian insang paling banyak terdapat di TPI Kamal Muara sebanyak 11 ekor diikuti oleh TPI Muara Angke sebanyak 10 ekor, TPI Cilincing sebanyak 7 ekor dan TPI Muara Baru sebanyak 5 ekor. Kerang darah yang terinfeksi pada organ mantel saja hanya terdapat di TPI Muara Angke, yaitu sebanyak 1 ekor. Kerang darah yang terinfeksi di bagian insang dan mantel paling banyak terdapat di TPI Cilincing sebanyak 5 ekor, diikuti oleh TPI Muara Angke sebanyak 4 ekor TPI Muara Baru sebanyak 3 ekor dan TPI Kamal Muara sebanyak 3 ekor (Gambar 8). 


\subsubsection{Kerang Hijau (Perna viridis)}

Kerang hijau (Perna viridis) yang diperoleh selama penelitian adalah berjumlah 32 ekor di TPI Muara Angke, 33 ekor di TPI Kamal Muara, 30 ekor di TPI Muara Baru, 27 ekor di TPI Cilincing (Tabel 2).

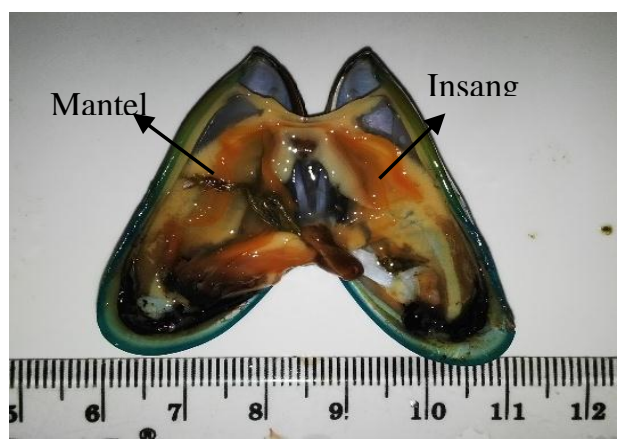

Gambar 9. Kerang Hijau (Perna viridis) yang sehat (Data Primer, 2014)

Seluruh kerang hijau yang diambil sampelnya tidak menunjukkan terinfeksi Perkinsus sp.. Hal ini juga didukung oleh gejala klinis pada Gambar 9 bahwa kerang hijau memiliki kondisi insang dalam keadaan yang baik dan cerah serta kondisi pada mantel yang berwarna cerah.

\subsubsection{Pemeriksaan PCR (Polymerase Chain Reaction)}

Pada penelitian ini dapat dideteksi keberadaan Perkinsus sp. pada setiap lokasi perdagangan kerang di wilayah DKI Jakarta, meliputi TPI Muara Angke, TPI Kamal Muara, TPI Muara Baru dan TPI Cilincing ditunjukkan dengan adanya pita positif pada besaran $703 \mathrm{bp}$ dari hasil foto gel agarose yang sudah di elektroforesis. Keberadaan Perkinsus sp. di TPI Muara Angke dapat dilihat pada Gambar 10.

\section{Pemeriksaan PCR (Polymerase Chain Reaction)}

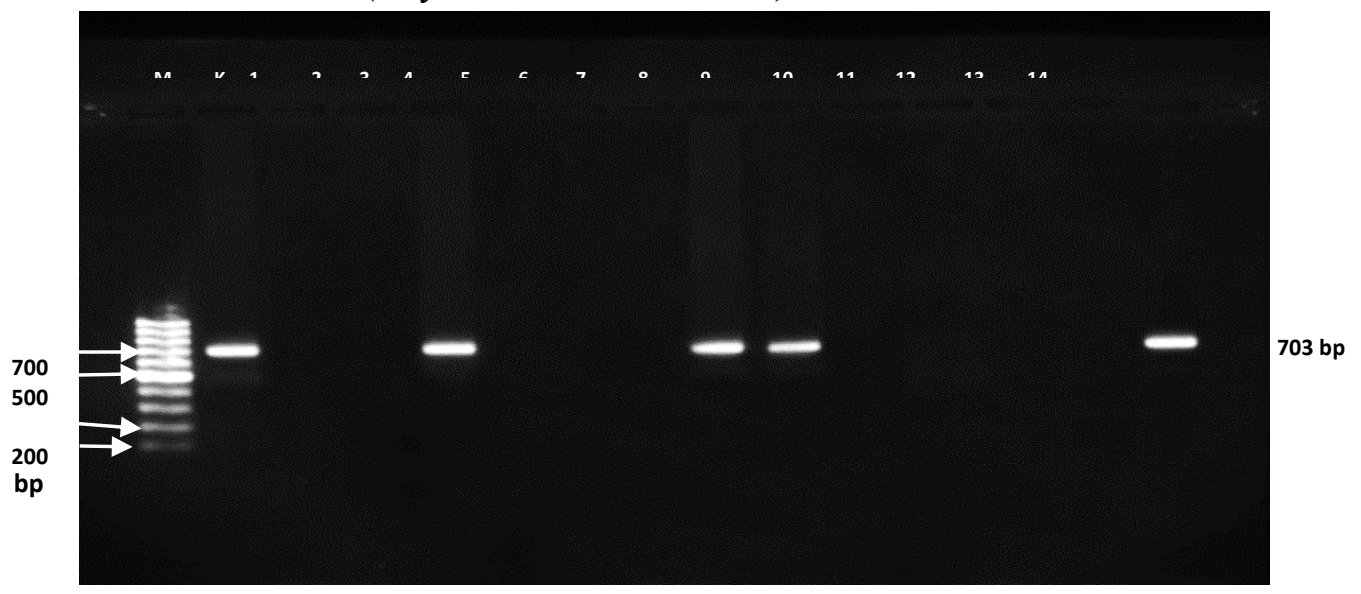

Gambar 10. Hasil Pemeriksaan PCR Menggunakan Primer Spesifik genus i’erkinsus yang kemudian Dielektroforesis dari Sampel Kerang Uji di TPI Muara Angke

$\begin{array}{ll}\text { Keterangan : } & \\ \mathrm{M} & \text { : Penanda DNA } \\ \mathrm{K} & \text { : Kontrol Positif Perkinsus sp. } \\ 1 \text { dan } 2 & \text { : Insang dan Mantel K.1.MA.I } \\ 3 \text { dan } 4 & \text { : Insang dan Mantel K.2.MA.I } \\ 5 \text { dan } 6 & \text { : Insang dan Mantel K.3.MA.I } \\ 7 \text { dan } 8 & \text { : Insang dan Mantel K.4.MA.I } \\ 9 \text { dan } 10 & \text { : Insang dan Mantel K.5.MA.I } \\ 11 \text { dan } 12 & \text { : Insang dan Mantel K.6.MA.I } \\ 13 \text { dan } 14 & \text { : Insang dan Mantel K.7.MA.I }\end{array}$




\section{Pembahasan}

Dari hasil yang diperoleh selama penelitian, pada gejala klinis kerang darah dan kerang bulu yang terinfeksi Perkinsus sp. menunjukkan insang dan mantel yang mengkerut dan berwarna pucat. Hal ini sesuai dengan Petty (2010) yang menyatakan bahwa inang yang terinfeksi kemungkinan mulutnya menganga, warna pucat pada saluran pencernaan, mantel pada inang terlepas, namun pada dasarnya gejala klinis pada inang yang terinfeksi tidak spesifik dan hanya bisa dilakukan konfirmasi pada uji PCR untuk menentukan ada tidaknya parasit Perkinsus sp. ini. Baker, et al. (2007) juga mengungkapkan hal yang sama bahwa kerang yang terinfeksi memiliki tanda-tanda cangkang yang tidak dapat menutup, lecet pada permukaan kulit bagian dalam, produksi lendir berlebihan, daging terlihat berair, gelap, pucat, atau daging berubah warna, luka atau borok pada mantel, otot aduktor, kaki, mantel mengkerut atau tepi mantel membengkak. Gejala klinis ini seringkali tidak menunjukkan inang yang terinfeksi, kemungkinan bisa berhubungan dengan penyakit non infektif dan perubahan pada lingkungan. Kerang hijau yang telah dilakukan pengamatan gejala klinis dan secara PCR tidak menunjukkan keberadaan Perkinsus sp. hal ini dikarenakan kerang hijau memiliki sistem kekebalan tubuh yang lebih baik daripada kerang bulu dan kerang darah. Hal ini sesuai dengan Wang, et al. (2012) di mana ketika terjadi kenaikan suhu dan salinitas, sistem peredaran darah / hemosit pada kerang hijau akan meningkat, sehingga penyakit yang akan menyerang peredaran darah difagosit oleh sel darah pada kerang hijau.

Prevalensi Perkinsus sp. pada TPI Kamal Muara memiliki prevalensi tertinggi bila dibandingkan dengan TPI Muara Baru. Perbedaan prevalensi pada setiap lokasi dikarenakan perbedaan masa inkubasi Perkinsus sp. pada kerang yang terinfeksi, selain itu perbedaan kondisi kualitas perairan pada lokasi penangkapan kerang secara tidak langsung berpengaruh terhadap penyebaran Perkinsus sp. ini, di mana media air merupakan perantara tersebarnya zoosporangia Perkinsus sp. antar kerang dari kerang yang sakit menuju kerang yang sehat. Hal ini diperkuat oleh pendapat Australian Government (2014), bahwa masa inkubasi Perkinsus sp. berlangsung selama 3 hari pada suhu $28{ }^{\circ} \mathrm{C}$. Satu ekor parasit yang berada dalam jaringan kerang akan berkembang selama 3 hari melakukan pembelahan secara biner dengan merusak sel darah merah pada kerang dan akan menghasilkan ratusan zoospora yang akan menginfeksi kerang, setelah kerang mati zoospora tersebut akan meninggalkan inangnya dan akan mencari inang yang sehat untuk diinfeksi.

Persentase Perkinsus sp. hasil pemeriksaan pada kerang darah dan kerang bulu pada jaringan insang selalu lebih tinggi dibandingkan pada organ mantel baik pemeriksaan di TPI Muara Angke, TPI Kamal Muara, TPI Muara Baru dan TPI Cilincing. Haltersebutsesuaidengan Choi \& Park (2010), bahwainsangselalumerupakan target utamaseranganPerkinsus sp. karena sifat kerang mengambil makanannya dengan cara filter feeder sehingga air selalu masuk dan tersaring melalui insang. Hal ini sesuai dengan pendapat Allam, et al. (2013)bahwa sel Perkinsus sp. yang berenang bebas di perairan akan dipompa ke dalam rongga pallial dan ditangkap pada insang, pada organ insang Perkinsus sp. akan berkembang dan mengalami inkubasi selama 3 hari, kemudian akan menginfeksi jaringan lainnya, sel parasit juga masuk ke rongga pada mantel yang selanjutnya berkembang dan infektif, sisa-sisa parasit yang tidak tertelan akan dibuang sebagai feses melalui anus. Sisa feses ini yang kemudian akan bersifat infektif dan menular bagi kerang yang sehat lainnya. Pada kerang yang terinfeksi akan mengalami kematian dan membusuk, sehingga pada akhirnya sisasisa jaringan yang terdapat prasit Perkinsus sp. ini akan menular ke perairan. Timbulnya penyakit pada kerang mempunyai hubungan yang erat dengan keadaan lingkungan, dimana kerang itu hidup.Hubungan erat antara kerang, patogen, lingkungan harus seimbang agar tidak timbul penyakit. Kerang hidup di lingkungan air maka bila terjadi perubahan sedikit saja dari lingkungan dapat menyebabkan stress pada kerang, sedangkan kerang yang dalam keadaan stress akan mudah terkena penyakit.Organisme penyebab penyakit itu sendiri (patogen) telah ada dalam perairan, tetapi dalam kondisi yang seimbang patogen tersebut tidak menyebabkan kerang menjadi sakit. Jika kondisi yang seimbang tersebut terganggu misalnya adanya perubahan lingkungan maka patogen yang ada dalam air dapat menyebabkan kerang menjadi sakit.

Pada pemeriksaan PCR diperoleh hasil dokumentasi pita DNA Perkinsus sp. dengan ketebalan yang berbeda-beda. Hal ini disebabkan oleh proses PCR sudah berjalan tetapi kurang optimal sehingga proses perbanyakan molekul DNA tidak berjalan dengan sempurna. Kekurang optimalan proses PCR ini bisa terjadi karena kurang sesuainya suhu annealing, proses ekstraksi DNA tidak mendapatkan DNA yang murni atau adanya kontaminasi. Pada penelitian ini gambaran DNA positifPerkinsus sp. pada kerang darah dan kerang bulu yang didapat di TPI Muara Angke, TPI Kamal Muara, TPI Muara Baru dan TPI Cilincing pada besaran amplifikasi 703 bp sesuai dengan target primer universal yang digunakan oleh peneliti seperti yang di terbitkan oleh Audemard, et al.(2004). 
Dari hasil penelitian diperoleh data bahwa DKI Jakarta merupakan wilayah yang sudah terdapat parasit Perkinsus sp.. Keberadaan parasit Perkinsus sp. di DKI Jakarta sangat dimungkinkan jika dilihat dari peta penyebarannya di dunia yang telah meliputi 5 benua, Indonesia sendiri adalah negara yang diapit oleh dua benua yaitu benua Asia dimana telah terdeteksi keberadaan Perkinsus sp. di negara Korea, Jepang, China pada kerang Manila Clam (Ruditapes philippinarum) dan juga benua Australiayang menemukan keberadaan Perkinsus sp. pada kerang Abalone dan Oyster. Keberadaan Perkinsus sp. pada jenis kerang darah dan kerang bulu di Indonesia khususnya pada wilayah DKI Jakarta juga sangat dimungkinkan mengingat penelitian sebelumnya pernah dilakukan di Australia pada survey dari beberapa penyakit parasit dan beberapa spesies kerang di Australia Barat Utara terhadap penyakit organisme akuatik ditemukan keberadaan Perkinsus olseni pada kerang dari genus yang sama yaitu Anadara trapezia dan banyak jenis molusca lainnya termasuk Tridacna gigas, Tridacna maxima, Tridacna crocea dan Katelysia rhytiphora.

\section{KESIMPULAN DAN SARAN}

Kesimpulan dari hasil penelitian adalah sebagai berikut prevalensi tertinggi kerang bulu (Anadara inflata) yang terinfeksi Perkinsus sp. terdapat di TPI Muara Angke sebesar $46 \%$ diikuti TPI Kamal Muara sebesar $34 \%$, TPI Muara Baru $34 \%$ dan TPI Cilincing $32 \%$. Prevalensi tertinggi kerang darah (Anadara granosa) yang terinfeksi Perkinsus sp. terdapat di TPI Kamal Muara sebesar $50 \%$ diikuti TPI Muara Angke $43 \%$, TPI Cilincing $32 \%$ dan TPI Muara Baru $26 \%$, Persentase kehadiran Perkinsus sp. pada organ insang tertinggi di TPI Muara Angke sebesar 46\%, diikuti TPI Muara Baru dan TPI Kamal Muara sebesar 34\%, TPI Cilincing 32\%. Persentase kehadiran Perkinsus sp. pada mantel paling tinggi pada TPI Muara Angke sebesar $23 \%$ diikuti TPI Muara Baru sebesar 17\%, TPI Cilincing sebesar $16 \%$ dan TPI Kamal Muara sebesar $10 \%$. Persentase Perkinsus sp. pada organ insang tertinggi di TPI Kamal Muara sebesar 50\% diikuti TPI Muara Angke sebesar 44\%, TPI Cilincing sebesar 32\% dan TPI Muara Baru sebesar 26\%. Persentase Perkinsus sp. pada mantel tertinggi pada TPI Muara Angke sebesar 16\%, diikuti TPI Cilincing sebesar 13\%, TPI Kamal Muara sebesar $11 \%$ dan TPI Muara Baru sebesar 10\%, kerang bulu (Anadara inflata) dan kerang darah (Anadara granosa) ada yang terinfeksi hanya pada organ insang dan mantel saja serta ada yang terinfeksi pada kedua organ insang dan mantel.

Berdasarkan hasil penelitian ini maka beberapa saran dapat diberikan perlu dilakukan penelitian keberadaan parasit Perkinsussp. pada berbagai jenis kerang yang ada dan pada lokasi yang berbeda di Indonesia agar diketahui jenis-jenis kekerangan apa saja yang sudah terinfeksi parasit Perkinsus sp. dan diketahui daerah mana saja yang sudah terinfeksi sehingga perlu dilakukan pengawasan, Perlu dilakukan penelitian terhadap parasit Perkinsus sp. pada tingkat spesies untuk memudahkan dalam pengawasannya dan pencegahannya.

\section{DAFTAR PUSTAKA}

Allam, B. et al., 2013. Early host-pathogen interactions in marine bivalves: Evidence that the alveolate parasite Perkinsus marinus infects through the oyster mantle during rejection of pseudofeces. Journal of Invertebrate Pathology, Volume 113, pp. 26-34.

Amos, K. H., 1985. Procedures for detection and identification of certain fish pathogen. 3rd Edition penyunt. Oregon: Fish Health Section American Fisheries Society.

Audemard, C., Reece, K. S. \& Burreson, E. M., 2004. Real-Time PCR for Detection and Quantification of the Protistan. Applied and Enviromental Microbiology Vo.70, pp. 6611-6618.

Australian Government, 2012. Infection with Perkinsus marinus. Aquatic Animal Disease Significant to Australia, Volume Vol. 4.

Australian Government, 2014. Aquatic Animal Diseases Significant to Asia-Pacific Identification Field Guide. [Online], http://library.enaca.org/Health/FieldGuide/html/mp050per.htm[13 Agustus 2014].

Baker, S. et al., 2007. Introduction to Infectious Diseases in Hard Clams, Florida: University of Florida.

Barnes, R. D., 1982. Coasts and Estuaries. London: Hodder \& Staughton.

Carnegie, R. B. \& Burreson, E. M., 2009. Status of The Mayor Oyster Diseases in Virginia 2006-2008, Virginia: Virginia Institute of Marine Science The College of William and Mary Gloucester Point.

Carpenter, K. E. \& Niem, V. H., 1998. FAO Species Identification Guide for Fishery Purposes. The Living Marine Resources of the Western Central Pacific.. Volume 1: Seaweeds, corals, bivalves and gastropods penyunt. Rome: Food And Agriculture Organization Of The United Nations. 
Choi, K. S. \& Park, K. I., 2010. Review on The Protozoan Parasite Perkinsus olseni (Lester and Davis 1981) Infection in Asian Waters. Coastal Environmental and Ecosystem Issues of The East China Sea, pp. 269-281.

Colosimo, S. L., 2007. Comparison of Perkinsus Marinus Infection and Oyster Condition in Southeastern North Carolina Tidal Creeks, North Carolina: Department of Biology and Marine Biology University of North Carolina Wilmington.

Department of Agriculture, Fisheries and Forestry Australian Government, 2012. Aquatic Animal Diseases Significant to Australia: Identification Field Guide. Infection With Perkinsus olseni, Volume 4th Edition, pp. 190-195.

FAO, 2014. FAO Fisheries and Aquaculture Department. [Online]. http://www.fao.org/fishery/statistics/software/fishstatj/en,[02 Mei 2014].

Hine, M., 2009. The Distribution of Perkinsus olseni in New Zealand Bivalve Mollusc, Wellington: National Centre for Disease Investigation.

Joseph, S. J. et al., 2010. The Alveolata Perkinsus marinus: Biological Insights from EST Gene Discovery.

Kastoro, W., 1988. Budidaya Jenis-Jenis Kerang (Bivalvia). Semarang: Universitas Diponegoro.

Kementerian Kelautan dan Perikanan, 2013. Keputusan Menteri Kelautan dan Perikanan NOMOR 26/KEPMEN-KP/2013 tentang penetapan jenis-jenis hama dan penyakit ikan karantina, golongan, media pembawa, dan sebarannya. Jakarta: Kementerian Kelautan dan Perikanan.

Kim, H. J. et al., 2012. Ultrastructure of Perkinsus olseni zoospores parasitizing the Manila clam Ruditapes philippinarum in Korea. The Korean journal of malacology, Volume 28, pp. 65-71.

Mahmuddin, 2010. Mahmuddin Belajar dan Berbagi. [Online] Available at: http://mahmuddin.wordpress.com/2010/08/31/polymerase-chain-reaction-pcr/[Diakses 1206 2014].

Menteri Negara Lingkungan Hidup, 2004. Keputusan Menteri Negara Lingkungan Hidup Nomor 51 Tahun 2004 Tentang Baku Mutu Air Laut. Jakarta: Menteri Negara Lingkungan Hidup.

Nasution, R., 2013. Teknik Sampling. [Online], http://library.usu.ac.id/download/fkm/fkm-rozaini.pdf[25 Juni 2014].

Nontji, 1987. Laut Nusantara. Jakarta : Penerbit Djambatan.

Nybakken, J. W., 1992. Biologi Laut Suatu Pendekatan Ekologis. Jakarta: PT. Gramedia.

Page, et al., 1998. Basic Epidemiological Methods and Biostatistics. London: s.n.

Petty, D., 2010. Perkinsus Infections of Bivalve Molluscs. Series of the Fisheries and Aquatic Sciences Department, UF/IFAS Extension.

Retnoningrum, D. S., 1997. Penerapan Polymerase Chain Reaction (PCR) untuk Diagnosis Penyakit Infeksi. Bandung: Jurusan Farmasi FMIPA ITB.

Robert, D. et al., 1982. Shallow Water Marine Mollucs of North-West Java. Jakarta: Lembaga Oseanologi Nasional.

Sudjana. 2002. Metode Statistika. Bandung: Tarsito.

Soniat, T. M., 2012. Levels of the parasite Perkinsus marinus in populations of oysters from the Louisiana Public Seed Grounds: Summer 2012, Lousiana: Louisiana Department of Wildlife and Fisheries.

Sunila, I., 2008. Dermo Disease, Connecticut: Connecticut Departement of Agriculture.

Universitas Gajah Mada, 2013. Teknik Budidaya Bivalvia, Yogyakarta: Universitas Gajah Mada.

Villalba, A. et al., 2004. Perkinsosis in molluscs: A review. Aquatic Living Resources, pp. 411-432.

Wang, Y. et al., 2012. Immune paramater changes of hemocytes in green lipped mussel Perna viridis exposure to hypoxia and hyposalinity. Aquacultur, Volume 356-257, pp. 22-29.

Wijayalath, W. et al., 2014. Humanized HLA-DR4 Mice Fed with the Protozoan Pathogen of Oyster Perkinsus marinus (Dermo) Do Not Develope Noticeable Pathology but Elicit Systemic Immunity. Plos One, 9(1). 


\title{
FEKUNDITAS OPTIMAL IKAN RAINBOW BOESMANI (Melanotaenia boesemani) DENGAN PERBANDINGAN BEBERAPA UKURAN
}

\author{
Iqbal Mujadid $^{1}$, Ediyanto $^{1}$, Nurhidayat ${ }^{2}$ \\ 1. Fakultas Perikanan dan Ilmu Kelautan USNI \\ 2. Balai Penelitian dan Pengembangan Budidaya Ikan Hias, KKP
}

\begin{abstract}
Research on fecundity optimal boesman's rainbowfish. Treatment from the point of view of the differences in the size of fish which is long p1 $(3,0-3,9 \mathrm{~cm}), \mathrm{p} 2$ $(4,0-4,9 \mathrm{~cm}), \mathrm{p} 3(5,0-5,9 \mathrm{~cm}), \mathrm{p} 4(6,0-6,9 \mathrm{~cm})$, and p5 (7,0-7,9cm ). The research uses design random complete 5 treatment and 6 repeat, if there were differences in treatment in the further by LSD test to know the differences in each treatment. The main parameters measured is the number of eggs total and relative and the gonad maturity level visually and microscopic. Treatment of five and six repeat was done, yields fish with a long 7,0-7,9 $\mathrm{cm}$ get the best result is fecundity a total 367 grains and fecundity relatively were 81 grains. The level of maturity the gonads highest obtained from 5th treatment that is long 7,0-7,9 $\mathrm{cm}$ parent with a maturity of the gonads stadium five.
\end{abstract}

Keyword : rainbow boesmani, fecundity, gonads maturity level.

\begin{abstract}
Abstrak
Penelitian tentang fekunditas optimal ikan Rainbow Boesmani. Perlakuan dilihat dari perbedaan ukuran yaitu panjang ikan P1(3-3,9cm), P2(4-4,9cm), P3(5$5,9 \mathrm{~cm}), \mathrm{P} 4(6-6,9 \mathrm{~cm})$, dan P5(7-7,9cm). Penelitian menggunakan Rancangan Acak Lengkap (RAL) 5 perlakuan dan 6 ulangan, apabila terdapat perbedaan pada perlakuan di uji lanjut dengan Uji BNT untuk mengetahui perbedaan pada tiap-tiap perlakuan. Parameter utama yang diukur adalah jumlah telur baik total maupun relatif dan tingkat kematangan gonad secara visual dan mikroskopis. Dari kelima perlakuan dan enam kali ulangan yang dilakukan, menghasilkan panjang ikan dengan ukuran $7-7,9 \mathrm{~cm}$ mendapatkan hasil terbaik yaitu fekunditas total sebanyak 367 butir dan fekunditas relatif sebanyak 81 butir. Tingkat kematangan gonad tertinggi diperoleh dari perlakuan ke-5 yaitu panjang induk $7-7,9 \mathrm{~cm}$ dengan tingkat kematangan gonad stadium lima (TKG-5)
\end{abstract}

Kata kunci : Rainbow Boesmani, fekunditas, tingkat kematangan gonad. 


\section{Pendahuluan}

Ikan hias merupakan salah satu komoditas andalan baru yang masih memerlukan upaya penanganan untuk pengembangan yang lebih intensif di Indonesia. Hal tersebut berakitan dengan potensi pasar internasional yang prospektif dan dukungan sumber daya yang melimpah. Pada tahun 2013, dari target produksi sebesar 1,1 miliar ekor, sampai dengan bulan Desember 2013 tercapai 1,04 miliar ekor atau 94,26\%. Wilayah produksi ikan hias Indonesia tersebar di 18 Propinsi di seluruh Indonesia, dengan sentra budidaya ikan hias terbesar terdapat di Jawa Timur, Jawa Barat, DKI Jakarta, Banten dan D.I. Yogyakarta. (KKP.go.id, 2014)

Berdasarkan data dari United Nation Commodity Trade Statistics Database, nilai ekspor ikan hias Indonesia pada tahun 2012 meningkat sebesar US\$ 21,015 juta, atau 8,12\% dari total nilai ekspor ikan hias di dunia yang mencapai US\$258,8 juta, sehingga Indonesia menempati posisi kelima di bawah Singapura, Spanyol, Jepang, dan Malaysia. (www.comtrade.un.org, 2014 ).

Permasalahan yang diangkat dalam penelitian ini berasal dari pembenihan ikan hias Rainbow Boesemani (Melanotaenia boesemani) yang telah dilakukan sebelumnya, dimana fekunditas ikan Rainbow Boesmani lebih rendah dari hasil pembanding. Hal ini diduga karena ikan Rainbow Boesmani yang dipijahkan baru pertama kali memijah dengan rata-rata ukuran di kisaran $3-4 \mathrm{~cm}$, selain itu ikan Rainbow Boesmani masuk kategori terancam keberadaannya di alam menurut IUCN Red List (1994) karena ikan Rainbow Boesmani di alam hidup terisolir di tiga danau di daerah Papua yang rentan dengan eksploitasi manusia sehingga kelangsungan spesienya perlu dipertahankan melalui proses budidaya.

\section{Metodologi}

Kegiatan penelitian ini akan dilaksanakan selama empat Bulan mulai dari Bulan Mei sampai Agustus 2015 yang bertempat di Balai Penelitian dan Pengembangan Budidaya Ikan Hias, Jalan Perikanan No. 13 Pancoran Mas Depok. Peralatan yang akan digunakan adalah keperluan yang dipergunakan selama penelitian, baik yang berasal dari fasilitas BPPBIH, pengadaan pribadi, maupun pihak lain yang membantu hingga terlaksananya seluruh metode yang dijalani. Bahan yang akan digunakan dalam penelitian ini adalah pakan yang diberikan selama persiapan induk dan proses pemijahan yaitu cacing darah (Chironomus Sp.) untuk menunjang pertumbuhan dan kematangan gonadnya. Ikan Rainbow Boesmani (Melanotaenia boesemani) yang digunakan dalam penelitian ini adalah benih ikan yang berasal dari Balai Penelitian dan Pengembangan Budidaya Ikan Hias Depok, kios dan pasar ikan hias dengan ukuran 3,0-7,9 cm dengan mengesampingkan faktor pengalaman indukan tersebut memijah. 
Metode yang digunakan dalam penelitian adalah metode eksperimen dengan analisis rancangan acak lengkap (RAL) satu faktor dengan 5 perlakuan ukuran induk serta 6 ulangan. Sehingga jumlah suatu percobaan adalah 30 unit akuarium dengan padat tebar 1 ekor jantan dan 1 ekor betina, pemeliharaan dilakukan didalam ruangan terkontrol. perlakuan ini menggunakan perbedaan panjang indukan.

$$
\mathbf{Y i j}=\boldsymbol{\mu}+\mathbf{t i}+\mathbf{e i j}
$$

Yij : Data hasil pengamatan pada perlakuan ke-i dan ulangan ke-j

$\mu \quad$ : Nilai tengah dari pengamatan

ti : Pengaruh aditif dari perlakuan ke-i

eij : Pengaruh galat hasil percobaan pada perlakuan ke-i dan ulangan

ke-j (Steel dan Torrie,1991)

Kualitas air yang diamati sejak tahap pemeliharaan induk sampai tahap perlakuan dilakukan 7 hari sekali. Pengamatan perkembangan gonad yang dilakukan dengan membuat preparat histologis ovarium. Pengamatan dilakukan 3 kali pada tiap-tiap sampel perlakuan yaitu saat awal seleksi induk, saat pemeliharaan induk dan saat pemijahan.

Data yang diperoleh selanjutnya dianalisis ragam (ANOVA) untuk mengetahui pengaruh ukuran terhadap fekunditas. Apabila terdapat perbedaan akan di uji lanjut (BNT) untuk melihat perlakuan terbaik.

$$
B N t_{\alpha}=\left(t_{\alpha, d f_{e}}\right) \cdot \sqrt{\frac{2\left(M S_{E}\right)}{r}}
$$

Parameter yang dianalisis yaitu tingkat kematangan gonad, fekunditas, derajat pembuahan, dan derajat penetasan.

\section{Hasil dan Pembahasan}

Hasil yang diperoleh berdasarkan pengukuran, pengamatan dan uji yang dilakukan diuraikan sebagai berikut.

Tabel Bobot Induk

\begin{tabular}{|c|c|c|c|}
\hline \multirow{2}{*}{ Perlakuan } & \multicolumn{3}{|c|}{$\begin{array}{c}\text { Berat Induk } \\
(\mathbf{m g})\end{array}$} \\
\cline { 2 - 4 } & H0 & H10 & H20 \\
\hline $\mathrm{P}_{1}$ & 550 & 570 & 1000 \\
\hline $\mathrm{P}_{2}$ & 1100 & 1300 & 1500 \\
\hline $\mathrm{P}_{3}$ & 2300 & 2400 & 3280 \\
\hline $\mathrm{P}_{4}$ & 3400 & 3900 & 4030 \\
\hline $\mathrm{P}_{5}$ & 4900 & 5200 & 6410 \\
\hline
\end{tabular}


Penimbangan bobot induk sejak $\mathrm{H}_{0}$ pemeliharaan induk sampai $\mathrm{H}_{20}$ dengan pemberian pakan chironomus menunjukan peningkatan pada bobot induk.

Tingkat kematangan gonad baik secara visual maupun mikroskopis menunjukan perbedaan nyata pada tiap-tiap perlakuan. Pada gambar 2 dan 3
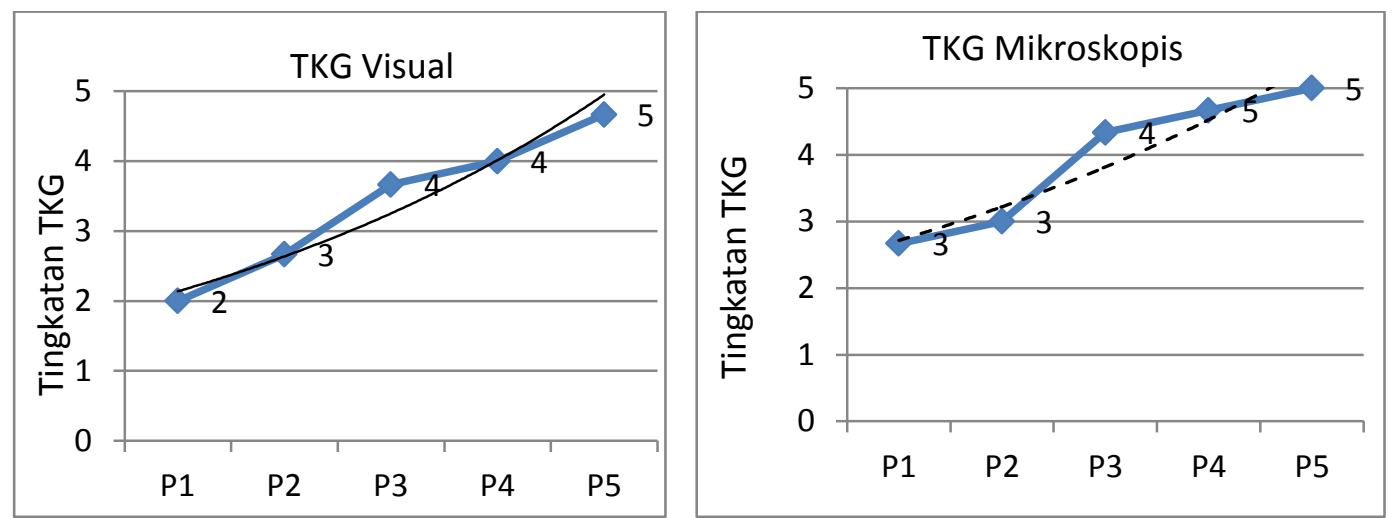

Grafik menunjukan bahwa semakin panjang induk ikan rainbow boesmani, maka semakin tinggi tingkat kematangan gonad nya. Hasil ANNOVA dari Uji Rancangan Acak Lengkap yaitu pengamatan TKG secara visual diperoleh pelakuan ke-5 panjang ikan $7-7,9 \mathrm{~cm}$ sebagai perlakuan terbaik sesuai dengan pernyataan Pusey et al (2011) Ovari-ovari berwarna kuning oranye dengan beberapa tembus cahaya sekeliling telur-telur globul-globul minyak membentuk massa tunggal terpolarisasi.

Berdasarkan hasil pengamatan mikroskopis tingkat kematangan gonad ikan Rainbow Boesmani, didapatkan hasil terbaik pada perlakuan ke-5 yaitu ikan dengan ukuran 7-7,9cm, sesuai dengan pernyataan Chinabut et al, (1991). Oosit stadium matang ditandai dengan oosit membulat dan ditandai warna merah muda terang dan terdapat beberapa inti sel yang sudah bermugrasi, dinding sel menipis.

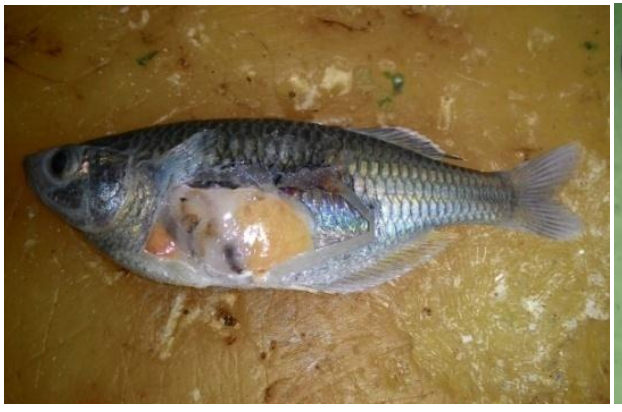

Gambar 8. TKG Visual

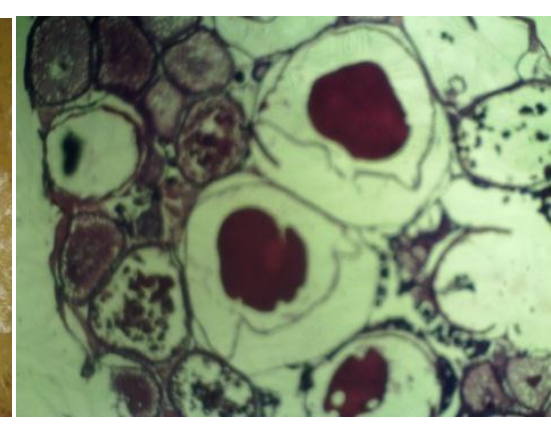

Gambar 9. TKG Mikroskopis

Perbandingan antara bobot induk dengan bobot gonad tidak berpengaruh nyata terhadap perlakuan panjang indukan. Berat bobot gonad meningkat seiring dengan meningkatnya bobot ikan 


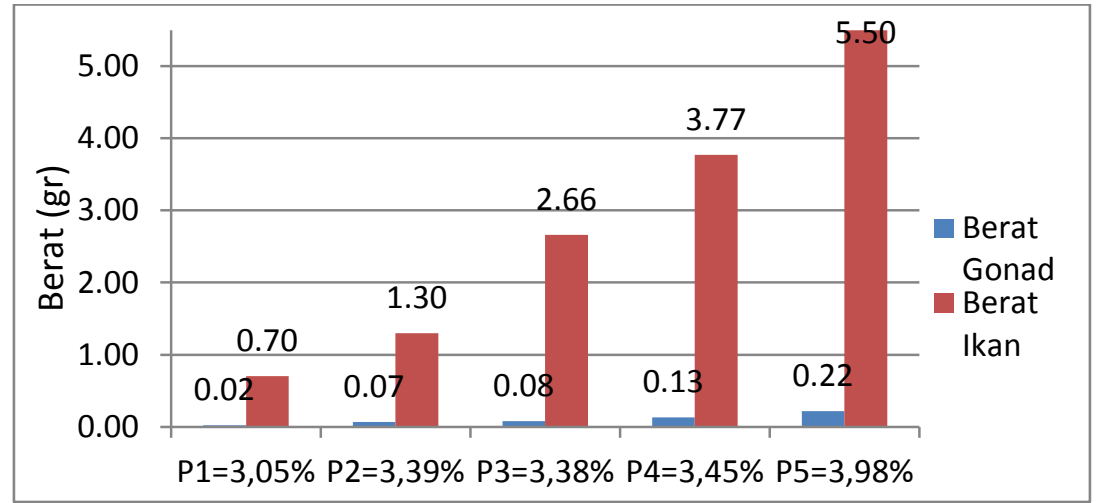

Sesuai dengan pernyataan Effendie (1997) bahwa gonad ikan semakin bertambah berat diimbangi dengan bertambah besar ukurannya, karena sebagian besar hasil metabolisme tertuju untuk perkembangan gonad. Woynarovich \& Horvath (1980) menyatakan bahwa jumlah telur ikan dapat dipengaruhi oleh bobot tubuh induk betina dan ukuran diameter telur.

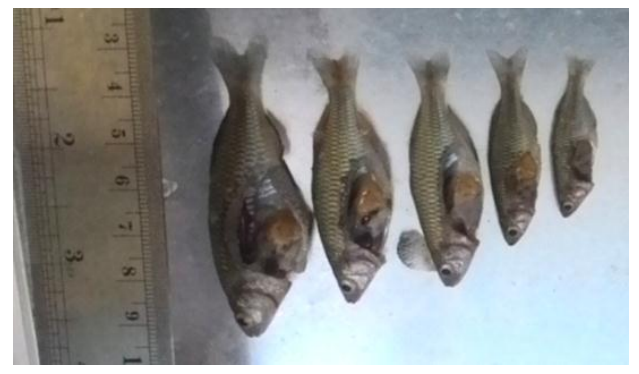

Perlakuan panjang indukan berpengaruh terhadap diameter telur induk ikan Rainbow boesmani menunjukan perbedaan yang nyata dan sangat nyata, sesuai dengan pernyataan Bastiar (2011) bahwa ikan pelangi dengan ukuran kecil memiliki rata-rata diameter telur yang kecil, sedangkan ikan pelangi yang berukuran besar rata-rata diameter telurnya lebih besar, dengan demikian, diameter telur terbesar yaitu $1,15 \mathrm{~mm}$ terdapat pada perlakuan ke-5 yaitu ikan dengan panjang $7-7,9 \mathrm{~cm}$.

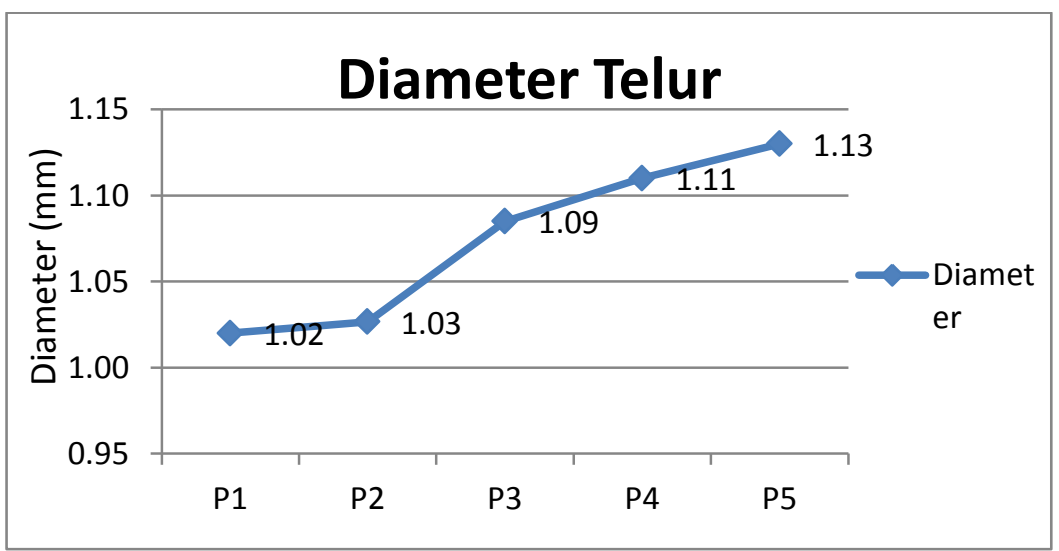


Perlakuan perbedaan panjang indukan berpengaruh nyata terhadap fekunditas ikan Rainbow Boesmani, baik fekunditas total maupun relatif sesuai dengan pernyataan Wotton, 1979 bahwa Pertambahan panjang tubuh ikan akan meningkatkan jumlah fekunditas, karena rongga tubuh tempat ovari akan semakin besar.

Tappin (2010), menambahkan bahwa jumlah telur yang dikeluarkan oleh satu ekor betina berkaitan dengan ukurannya, jumlah total telur yang dikeluarkan akan meningkat seiring meningkatnya ukuran serta tingkat kematangan gonadnya. Data yang dihasilkan menunjukan perlakuan ke-5 ikan dengan panjang $7-7,9 \mathrm{~cm}$ adalah perlakuan dengan jumlah fekunditas total dan relatif terbanyak.
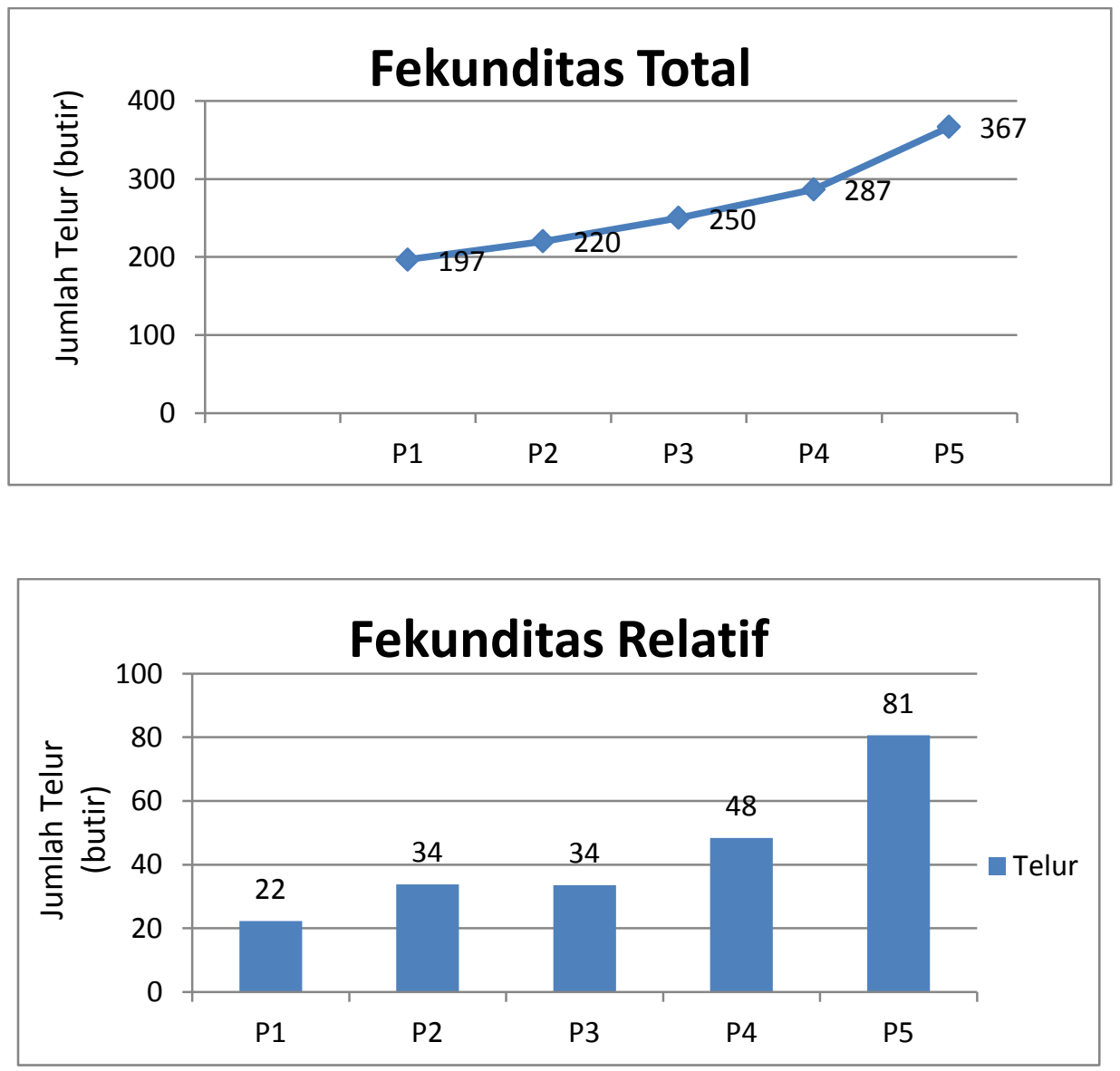

Derajat pembuahan dan penetasan telur ikan Rainbow Boesmani terlihat cukup tinggi dengan nilai rata-rata $94,3 \%$ untuk derajat pembuahan pada seluruh perlakuan dan $88,7 \%$ untuk nilai rata-rata derajat penetasan pada seluruh perlakuan, sesuai dengan hasil pembanding pada domestikasi ikan pelangi oleh Bastiar Nur (2011) yaitu $98,81 \%$ pada pembuahan dan $84,86 \%$ untuk penetasan. 
Tabel Fertilitas Telur

\begin{tabular}{|c|c|c|c|c|}
\hline Perlakuan & $\begin{array}{c}\text { Fekunditas } \\
\text { (butir) }\end{array}$ & $\begin{array}{c}\text { Fertil } \\
\text { (butir) }\end{array}$ & $\begin{array}{c}\text { Infertil } \\
\text { (butir) }\end{array}$ & $\begin{array}{c}\text { Pembuahan } \\
(\boldsymbol{\%})\end{array}$ \\
\hline $\mathrm{P}_{1}$ & 67 & 63 & 4 & 94,03 \\
\hline $\mathrm{P}_{2}$ & 135 & 124 & 11 & 91,85 \\
\hline $\mathrm{P}_{3}$ & 201 & 195 & 6 & 97,01 \\
\hline $\mathrm{P}_{4}$ & 242 & 229 & 13 & 94,63 \\
\hline $\mathrm{P}_{5}$ & 484 & 455 & 29 & 94,01 \\
\hline & & & Rata-rata & $\mathbf{9 4 , 3 1}$ \\
\hline
\end{tabular}

Tabel Penetasan Telur

\begin{tabular}{|c|c|c|c|c|}
\hline Perlakuan & $\begin{array}{c}\text { Fertil } \\
\text { (butir) }\end{array}$ & $\begin{array}{c}\text { Menetas } \\
\text { (butir) }\end{array}$ & $\begin{array}{c}\text { Tidak Menetas } \\
\text { (butir) }\end{array}$ & $\begin{array}{c}\text { Penetasan } \\
(\boldsymbol{\%})\end{array}$ \\
\hline $\mathrm{P}_{1}$ & 63 & 50 & 13 & 79,37 \\
\hline $\mathrm{P}_{2}$ & 124 & 101 & 23 & 81,45 \\
\hline $\mathrm{P}_{3}$ & 195 & 180 & 15 & 92,31 \\
\hline $\mathrm{P}_{4}$ & 229 & 220 & 9 & 96,07 \\
\hline $\mathrm{P}_{5}$ & 455 & 429 & 26 & 94,29 \\
\hline & & & Rata-rata & $\mathbf{8 8 , 7 0}$ \\
\hline
\end{tabular}

Hasil pengamatan dan pengukuran kualitas air dari ketujuh parameter yang diukur menunjukan bahwa kualitas air selama pemeliharaan dan pemijahan masih dalam batas toleransi ikan tersebut, sehingga parameter kualitas air selama masa pemeliharaan sampai pemijahan masih dalam kondisi layak untuk kehidupan dan perkembangbiakan ikan Rainbow Boesmani.

\begin{tabular}{cccccc}
\hline \multirow{2}{*}{ Parameter } & \multicolumn{5}{c}{ Perlakuan } \\
\cline { 2 - 6 } & $\mathbf{P}_{\mathbf{1}}$ & $\mathbf{P}_{\mathbf{2}}$ & $\mathbf{P}_{\mathbf{3}}$ & $\mathbf{P}_{\mathbf{4}}$ & $\mathbf{P}_{\mathbf{5}}$ \\
\hline Suhu & $27,5-27,7$ & $27,5-28,2$ & $27,6-27,9$ & $27,5-27,9$ & $27,5-27,9$ \\
$\mathrm{pH}$ & $6,5-7,0$ & $6,5-7,0$ & $6,5-7,0$ & $6,5-7,0$ & $6,5-7,0$ \\
$\mathrm{DO}$ & $5,48-8,70$ & $5,45-7,00$ & $5,37-7,00$ & $5,28-7,4$ & $5,35-7,41$ \\
$\mathrm{NH}_{3}$ & $0,014-0,064$ & $0,011-0,098$ & $0,009-0,043$ & $0,007-0,085$ & $0,009-0,085$ \\
$\mathrm{NO}_{2}$ & $0,003-0,412$ & $0,001-0,507$ & $0,002-0,446$ & $0,001-0,340$ & $0,001-0,340$ \\
\hline Kesadahan & $24,26-35,67$ & $24,26-29,96$ & $27,11-35,67$ & $24,26-35,67$ & $24,26-27,11$ \\
\hline Alkalinitas & $21,22-31,83$ & $21,22-31,83$ & $21,22-34,87$ & $31,83-42,44$ & $21,22-42,44$ \\
\hline
\end{tabular}


Kesimpulan Perlakuan ke-5 panjang ikan 7,0-7,9 cm menghasilkan fekunditas tertinggi yaitu 81 butir pada fekunditas relatif ,dan 367 butir untuk fekunditas total. Tingkat kematangan gonad tertinggi diperoleh dari panjang ikan 7,0-7,9 cm diikuti panjang ikan 6,0-6,9 cm yaitu TKG-5. Perlu penelitian lebih lanjut tentang fekunditas dan tingkat kematangan gonad ikan Rainbow Boesmani sampai ukuran maksimal yaitu $8-9 \mathrm{~cm}$.

\section{Daftar Pustaka}

Anonymous. 2007. Ikan air tawar langka di Indonesia seri II. Direktorat Konservasi dan Taman nasional laut. Direktorat Jendral Kelautan, Pesisir dan PulauPulau Kecil. Departemen Kelautan dan perikanan. 52 hal.

Anonymous. 2015. http://s3.amazonaws.com/academia.edu.documents 31130684 /REPRODUKSI.docx [2 April 2015. 11.00 WIB]

Allen G.R., 1980. - A Generic Classification of the Rainbowfishes (Family Melanotaenidae). Rec. West. Aust. Mus.44 hal

Boesmans Rainbowfish. http://www.arkive.org / boesemans-rainbowfish /melanotaenia -boesemani/. [8 Januari 2015, 22.00]

Bastiar, N, 2011. Studi Domestikasi dan Pemijahan Ikan Pelangi Kurumoi (Melanotaenia parva) Sebagai Tahap Awal Konservasi Ex-Situ. BPPBIH. Depok. 9 hal.

Campbell, N. A. 2004. Biology. Erlangga. Jakarta. 295 hal.

Chinabut, S. Limswan, C. Kitsawat, P. 1991. Histology of the Walking Catfish, Clarias batrachus. IRDC. 93 hal.

Effendie, M.I. 1997. Metode Biologi Perikanan. Yayasan Pustaka Dwi Sri. Bogor

Effendi, H. 2000. Telaahan Kualitas Air Bagi Pengelolaan Sumberdaya dan Lingkungan Perairan. Fakultas Perikanan dan Ilmu Kelautan, IPB. Bogor. 258 hal.

IUCN Red List.1994. http://www.iucnredlist.org/details/13058/0. [8 Januari 2014]

Kadarini T, Agus M, dan Eni K. 2011. Dukungan Pembenihan Ikan Rainbow Boesemani (Melanotaenia boesemani) Terhadap Sumber Daya Ikan di Depok.

Kadarusman. 2010. Penemuan Jenis Baru Ikan Pelangi Papua Melanotaenia fasinensis dari Sorong Selatan, Penemuan Kembali M. ajamaruensis dan Status Kritis Hampir Punah M. parva di Danau Kurumoi Kabupaten Bintuni. Warta Riset Akademi Perikanan Sorong. Sorong.

KKP.go.id. 2014. Seminar Perkembangan Ikan Hias dengan Tema Sinergitas Stakeholder Mewujudkan Industrialisasi. http://www.kkp.go.id/ikanhias /index.php/news/c/99/Seminar-Pengembangan-Ikan-Hias-dengan-temaSinergitas-Stakeholder-Mewujudkan-Industrialisasi-/?category_id=1. [15.Desember 2014, pk 10.02] 
Muna, N. 2013. Teknik Pemijahan Ikan Rainbow Kurumoi Di BPPBIH. Depok. 41 hlm.

Nasution, S.H. 2000. Ikan Hias Air Tawar Rainbow. Penebar Swadaya. Jakarta

Pusey, B.J.; Arthington, A.H.; Bird, J.A. \& Close, P.G. 2001. Reproduction in Three Species of Rainbowfish (Melanotaeniidae) From Rainforest Streams in Northern Queensland, Australia. Ecology of Freshwater Fish. 87 hal

Steel RGD, Torrie JH. 1991. Prinsip dan Prosedur Statistika Suatu Pendekatan Biometrik. Jakarta. PT.Gramedia. 772 hal.

Tappin. 2010. Rainbow Fish: Their Care \& Keeping In Capasity. [http://www. rainbow fishes@ptunesnet.com.au] 493 hal

United Nation Commodity Trade Statistic Database. 2012. http://comtrade.un.org/db/ce/ceSnapshot.aspx?px=HS\&cc=03 Nopember 2014]

Wotton, R.J.1979. Energy Cost of Egg Production and Environmental of Fecundity of Teleost Fish. The Zoology Society of London. Academic Press London. 159 hal.

Woynarovich, E. \& L. Horvath. 1980. The Artificial Propagation of Warm Water Finfish, A Manual for Extention. FAO Fisheries Technical Paper. Roma, 201 hal. 


\title{
ANALISIS USAHA BUDIDAYA RUMPUT LAUT (Eucheuma cottonii) DI PULAU PARI, KEPULAUAN SERIBU
}

\author{
Husnul Syarifah Achsya Dinda ${ }^{1}$, Edward Danakusumah ${ }^{2}$, dan Urip Rahmani ${ }^{3}$ \\ ${ }^{1,2,3)}$ Fakultas Perikanan dan Ilmu Kelautan Universitas Satya Negara Indonesia, Jakarta
}

\begin{abstract}
Seaweed is one of the potential fishery resources that have been developed in Indonesia with good prospects. Because the demand of the seaweed increase it have a appect of the production of seaweed. This is reseach use primary data, secondary data followed with the related literature, using data analysis feasibility revenues $(R C$ Ratio, BEP,PP,ROI) and analysis investment criteria (NPV, Net B/C, IRR). The teknik that use by the fisherman of a seaweed in Pari Island, is a fandemental general realeas teknik the proses star from sead, maintanence of the growing seaweed and cultivation. The result of the analysis showing the the value $R / C: 3,02, B E P: R p$. 4.385.799,-, ROI: 1,2\% and PP: 4,08 and the result of investement of criteria showing the value NPV: Rp. 30.619.928, Net B/C: 2,529 and IRR: 89,23\%. the result of the cultivation is $600 \mathrm{~kg}$ of seaweed.
\end{abstract}

Keyword :Growing seaweed, Eucheuma cottonii, Pari Island

\begin{abstract}
ABSTRAK
Rumput laut merupakan salah satu potensi sumberdaya yang telah dikembangkan di Indonesia dengan memiliki prospek yang baik.Karena tingginya jumlah permintaan rumput laut maka menyebabkan produksi budidaya rumput laut makin meningkat. Metode dalam penelitian ini menggunakan data primer, sekunder serta studi literatur yang terkait, dengan menggunakan analisis data kelayakan pendapatan usaha (R-C Ratio, BEP, PP, ROI) dan analisis kriteria investasi (NPV, Net B/C, IRR). Teknik budidaya yang digunakan oleh nelayan rumput laut adalah teknik lepas dasar yang umum dilakukan oleh para nelayan di Pulau Pari, serta proses budidaya mulai dari pembibitan, pemeliharaan masa tanam dan pemanenan. Hasil dari analisis kelayakan pendapatan usaha menjukan nilai R/C: 3,02. BEP: Rp.4385.799,-. ROI: 1,2\%, dan PP: 4,08. Hasil dari analisis lriteria investasi dengan nilai NPV: Rp. 30.619.928. Net B/C: 2,529 dan IRR 89,23\%. Dengan hasil panen yang dicapai mendapatkan hasil $600 \mathrm{Kg}$ rumput laut.
\end{abstract}

Kata Kunci :Budidaya rumput laut, Eucheuma cottonii, Pulau Pari. 


\section{PENDAHULUAN}

Rumput laut di Indonesia merupakan salah satu potensi sumberdaya perairan yang sejak lama dimanfaatkan sebagai bahan pangan dan obat-obatan.Saat ini pemanfatan rumput laut telah mengalami peningkatan (Khordi dan Ghufran, 2010).Seiring peningkatan pemanfaatan rumput laut yang tinggi maka permintaan pasar pun semakin tinggi juga.Salah satu dari keberhasilan budidaya rumput laut adalah dengan cara memilih lokasi yang tepat untuk penanaman rumput laut. Budidaya rumput laut dilihat dari aspek teknis usaha ini sangat mudah dilakukan, selain itu dilihat dari prospek usaha budidaya rumput laut sangat menjanjikan karena dimulai dengan modal yang tidak terlalu banyak maka bisa mengasilkan keuntungan yang cukup tinggi dari usaha budidaya rumput laut (Anggadiredja, et al, 2011).

Propinsi DKI Jakarta mengembangkan budidaya rumput laut yang dilakukan di Pulau Pari Kepulauan Seribu. Karena itu untuk melihat pertumbuhan budidaya rumput laut dengan teknik lepas dasar perlu diamati. Tujuan dari penelitian ini untuk mengetahui aspek teknis dan menghitung analisis kelayakan usaha budidaya rumput laut di PulauPari sehingga nantinya dapat dikembangkan kembali usaha budidaya rumput laut yang sempat terhenti.

\section{METODOLOGI}

Penelitian ini dilaksanakan pada bulan Nobember sampai Desember 2013 yang bertempat di Pulau Pari, Kepulaun Seribu.Adapun alat yang digunakan adalah; gerobak panen, pisau, perahu, alat tulis, kamera, thermometer, sechi disk, refratometer dan kertas lakmus. Alat yang digunakan adalah bibit rumput laut Eucheuma cottonii, tali tambang besar ukuran $6 \mathrm{~mm}$, tali tambang kecil ukuran $3 \mathrm{~mm}$, pelampung dan bambu. Metode penelitian yang digunakan adalah metode pengumpulan data primer, sekunder serta studi literatur yang berhubungan dengan kegiatan analisis usaha budidaya rumput laut.Budidaya rumput laut dilakukan langsung kegiatan operasional budidaya dengan menggunakan teknik lepas dasar, bibit rumput laut dapat diperoleh di Pulau Pari kemudian proses pemeliharaan dan pemanenan. Pemeriksaan kontruksi teknik lepas dasar dilakukan setiap seminggu sekali saat air surut atau pada sore hari.Rumput laut Eucheuma cottonii dapat dipanen setelah 40 hari masa pemeliharaannya selanjutnya hasil dari panen budidaya rumput laut dapat dibawa ketengkulak atau dapat dijual secara langsung pada konsumen.

\section{Analisis Data}

Analisis data yang dilakukan dengan menghitung analisis kelayakan usaha budidaya rumput laut yang dapat dijelaskan pada rumus-rumus berikut ini:

\section{1) Analisis R/C Ratio}

Analisis imbangan penerimaan dan biaya ini bertujuan untuk mengetahui hasil yang diperoleh dari suatu kegiatan usaha dengan rumus (Hernanto, 1989): 
Dengan kriteria:

$\mathrm{R} / \mathrm{C}>1$ : usaha menguntungkan

$\mathrm{R} / \mathrm{C}=1:$ usaha tidak menguntungkan dan tidak rugi

$\mathrm{R} / \mathrm{C}<1$ : usaha rugi

\section{2) Analisis Break Event Point (BEP)}

Analisis ini untuk melihat titik impas yang bertujuan mengetahui sampai batas mana usaha yang dilakukan bisa memberikan keuntungan.Analisis ini menyatakan sebagai contoh jumlah tangkapan minimal yang harus diperoleh setiap tahun pada tingkat untung atau tidak rugi. Rumus yang digunakan adalah (Rahardi et al , 1993):

\section{3) Analisis Payback Period}

Payback Period adalah analisis pengembalian modal yangbertujuan untuk mengetahui berapa lama waktu yang diperlukan (dalam tahun atau bulan) untuk menutupi investasi dengan rumus (Hernanto, 1989):

\section{4) Analisis Return On Investment}

Return On Investement (ROI) adalah analisis tingkat pengembalian investasi yang merupakan analisis usaha yang digunakan untuk mengetahui berapa prosentase kemungkinan pengembalian keuntungan dari investasi yang ditanamkan dengan asumsi pendapatan setiap bulan atau tetap (Hernanto, 1989).

Rumus ROI adalah:

\section{Analisis Kriteria Investasi}

Analisis ini bertujuan untuk mengetahui apakah suatu usaha layak untuk dikembangkan atau tidak.Menurut Djamin (1993) dalam menghitung analisis ini dapat digunakan analisis sebagai berikut:

\section{1) Net Present Value (NPV)}

NPV adalah selisih antara Present Value (PV) arus benefit dengan PV arus biaya. Nilai NPV dapat dihitung dengan menggunakan rumus:

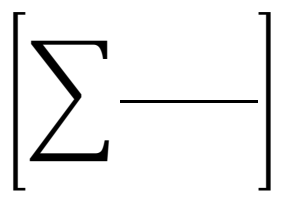


Dimana:

bt = annual gross benefit

ct $=$ annual costs

$(1+\mathrm{i})^{\mathrm{t}}=$ discounting factor $\left(\mathrm{D}_{\mathrm{F}}\right)$

Ko = initial investement

$\mathrm{t} \quad=\mathrm{n}$. menunjukkan umur ekonomis proyek

$\mathrm{t} \quad=1$, artinya tahun pertama proyek

Dengan kriteria:

NVP $>0 \quad$ : usaha layak untuk dijalankan

$\mathrm{NVP}=0 \quad$ : usaha layak/tidak layak dijalankan

NVP $<0 \quad$ : usaha tidak layak untuk dijalankan

\section{2) Benefit Cost Ratio (B/C)}

Benefit Cost Ratio adalah perbandingan antara total nilai sekarang dari penerimaan bersih yang bersifat positif dan total nilai sekarang penerimaan bersih bersifat negatif. Rumus yang digunakan adalah:

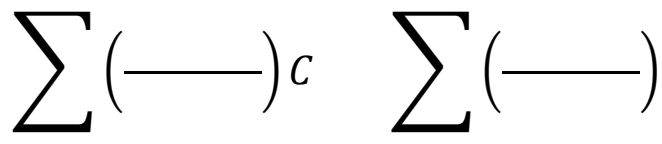

$($ Project Total Cost $=\mathrm{Ko}+\mathrm{C})$

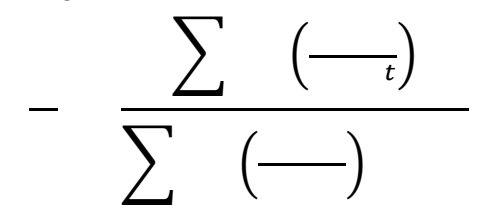

Dengan kriteria:

Net $\mathrm{B} / \mathrm{C} \geq 1 \quad$ : usaha layak dijalankan

Net $\mathrm{B} / \mathrm{C}<1$ : usaha tidak layak dijalankan

\section{3) Internal Rate of Return (IRR)}

Untuk menentukan berapa tepatnya tingkat bunga yang ideal, caranya adalah dengan melakukan percobaan-percobaan terus atau dengan menggunakan metode interpolasi/penyisipan diantara bunga yang lebih rendah (yang menghasilkan NPV positif) dengan tingkat bunga yang lebih tinggi (yang menghasilkan NPV negative) yang dapat dituangkan dalam rumus:

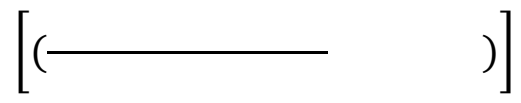

Dimana:

i' = tingkat suku bunga yang digunakan untuk menghasilkan present value positif 
ii” = tingkat suku bunga yang digunakan untuk menghasilkan present

value negatif

$\mathrm{PVP}=$ present value positif

$\mathrm{PVN}=$ present value negatif

Dengan kriteria:

IRR $>\mathrm{i} \quad$ : usaha layak dijalankan

IRR $<\mathrm{i} \quad$ : usaha tidak layak dijalankan

\section{HASIL DAN PEMBAHASAN}

\section{Gambaran Umum Budidaya Rumput Laut}

Beberapa gambaran umum tentang budidaya rumput laut di Pulau Pari, Kepulauan Seribu sebagai berikut:

1. Salah satu keberhasilan budidaya rumput laut adalah pemilihan lokasi yang tepat. Letak lokasi penanaman berjarak 5-10 m dari garis pantai. Lokasi penanaman harus mempunyai pergerakan air yang cukup bagus dan ditumbuhi oleh komunitas yang terdiri dari beberapa jenis makro alga.

2. Pemilihan benih berasal dari Pulau Pari karena benih yang berasal dari satu jenis rumput laut lebih murni. Cirir-ciri benih yang baik adalah benih halus muda, bersih dan segara agar memberikan pertumbuhan yang optimal.

3. Penanaman rmput laut menggunakan teknik lepas dasar dengan cara pemasangan bibit rumput laut pada tali ris kecil, kemudian dapat diikat pada tali ris utama dengan jarak $25-30 \mathrm{~cm}$. Cara penanamannya dengan mengikat bibit rumput laut pada ujung tali ris utama kepatok yang terbuat dari kayu, lalu kayu ditancapkan ke dasar perairan dengan bantuan besi panjang atau batu. Kemudian tali ris utama beserta bibit rumput laut yang telah diikatkan dibentangkan dengan alur mundur atau jalan ke belakang. Biasanya pada satu baris terdapat 3 tali yang disambung panjangnya 10 meter, jadi dalam satu baris terdapat 30 meter tali yang telah diikatkan bibit rumput laut. Setelah ujung tali yang terakhir diikatkan lagi dengan kayu dan kayu tersebut ditancapkan lagi ke dasar parairan. Setelah selesai, dipasangkan pelampung yang terbuat dari sterofom dengan jarak antar pelampung 1-2 $\mathrm{m}$ yang diikat pada tali ris utama.

4. Pemeliharaan yang dilakukan biasanya memeriksa tanaman, membersihkan sampah-sampah yang menempel, baik pada tali maupun pada rumput laut yang ditanam, memeriksa rumput laut yang terkena penyakit.

5. Rumput laut dipanen setelah mencapai umur lebih dari 40 hari setalah tanam. Cara pemanenan rumput laut dengan cara melepas patok yang ditancapkan di 
dasar perairan kemudian tali yang diikat pada patok dilepaskan setelah itu rumput laut yang terikat dengan tali dapat panen dan ditaruh diperahu sampan dan hasil panen tersebut diangkat ke darat

6. Pemasaran yang dilakukan oleh petani rumput laut dengan menjual ke pengepul atau dijual langsung pada konsumen akhir. Para petani menjual harga rumput laut basah dengan harga Rp. 6000/kg.

\section{Parameter Kulaitas Air}

Parameter kualitas perairan yang diukur dalam penelitian budidaya rmput laut seperti suhu, salinitas, $\mathrm{pH}$ dan kecerahan pada tiap minggunya dapat dijelaskan pada Tabel 1. Tabel 1. Parameter Kualitas Air

\begin{tabular}{|r|l|c|r|r|r|r|r|r|r|}
\hline \multirow{2}{*}{ No } & \multirow{2}{*}{ Parameter } & \multirow{2}{*}{ Satuan } & \multicolumn{9}{|c|}{ Minggu } \\
\cline { 4 - 10 } & & & \multicolumn{1}{c|}{0} & 1 & \multicolumn{1}{c|}{2} & \multicolumn{1}{c|}{3} & \multicolumn{1}{c|}{5} & \multicolumn{1}{c|}{6} \\
\hline 1 & Suhu & ${ }^{\circ} \mathrm{C}$ & 29 & 27 & 31 & 31 & 30 & 28 & 30 \\
\hline 2 & Salintas & \% & 31 & 31 & 31 & 32 & 31 & 31 & 31 \\
\hline 3 & $\mathrm{pH}$ & - & 8,1 & 8,0 & 8,1 & 8,4 & 8,3 & 8,0 & 8,3 \\
\hline 4 & Kecerahan & $\mathrm{M}$ & 1 & 1 & 1 & 1 & 1 & 1 & 1 \\
\hline
\end{tabular}

\section{Analisis Kelayakan Usaha Penerimaan Usaha}

Berdasarkan perhitungan penerimaan usaha budidaya rumput laut dalam waktu satu tahun mendapatkan hasil sebesar Rp. 14.400.000,- dari jumlah panen yang dikalikan dengan harga jual dan dikalikan lagi dengan produksi pertahun. Petani mendapatkan keuntungan pertahun sebesar Rp. 9.638.668,- dari total penerimaan dikurangi dengan total biaya. Dengan demikian para petani budidaya rumput laut banyak mengembangkan usaha sampingan ini yang menambah pendapatan para petani di Pulau Pari.Biasanya harga jual rumput laut di Pulau Pari adalah Rp. $6.000 / \mathrm{kg}$ untuk rumput laut basah.Produksi rumput mendapatkan hasil sebanyak 600 $\mathrm{Kg}$ dalam satu kali panen. Petani rumput laut dalam satu tahun biasanya bisa 4 (empat) kali panen rumput laut..

\section{Biaya Investasi}

Biaya investasi untuk usaha budidaya rumput laut sebesar Rp. 3.281.500 yang terdiri dari kebutuhan biaya penanaman seeperti tali ris besar, tali ris kecil, pelampung, kayu, pisau, sampan, gerobak yang dapat dilihat pada Tabel 2. 
Tabel 2. Rincian Biaya Investasi

\begin{tabular}{|l|c|r|r|r|r|}
\hline \multicolumn{1}{|c|}{ Uraian } & Satuan & Jumlah & \multicolumn{1}{c|}{$\begin{array}{c}\text { Harga } \\
\text { Satuan } \\
\text { (Rp) }\end{array}$} & \multicolumn{1}{c|}{$\begin{array}{c}\text { Jumlah/ } \\
\text { Produksi } \\
(\mathrm{Rp})\end{array}$} & $\begin{array}{c}\text { Jumlah/ } \\
\text { Tahun } \\
\text { (Rp) }\end{array}$ \\
\hline $\begin{array}{l}\text { Tali Tambang besar } \\
\text { berdiameter 6mm }\end{array}$ & $\mathrm{Kg}$ & 2 & 30.000 & 60.000 & 60.000 \\
\hline $\begin{array}{l}\text { TaliTambang kecil } \\
\text { beridameter 3 mm }\end{array}$ & $\mathrm{Kg}$ & 1 & 15.000 & 15.000 & 15.000 \\
\hline Perahu Sampan & Unit & 1 & 2.000 .000 & 2.000 .000 & 2.000 .000 \\
\hline Gerobak & Unit & 1 & 800.000 & 800.000 & 800.000 \\
\hline Pisau & Buah & 1 & 20.000 & 20.000 & 20.000 \\
\hline Kayu & Buah & 16 & 5.000 & 80.000 & 320.000 \\
\hline Pelampung & Buah & 190 & 350 & 66.500 & 66.500 \\
\hline Total & & & & & 3.251 .500 \\
\hline
\end{tabular}

\section{Biaya Produksi}

Biaya produksi adalah biaya selama usaha budidaya rumput laut dilakukan, biaya produksi terdiri atas biaya tetap dan biaya variabel. Biaya tetap per tahun untuk usaha budidaya rumput laut sebesar Rp. 4.221.332,- komponennya terdiri dari upah panen, biaya penyusutan dan biaya perawan. Sedangkan untuk biaya variabel yang dikeluarkan per tahun sebesar Rp. 540.000.- untuk pembelian bibit rumput laut.

\section{Analisis Imbangan Penerimaan dan Biaya ( $R$ - $C$ Ratio)}

Analisis imbangan penerimaan dan biaya menunjukkan sejauh mana pengaruh perubahan biaya oprasional terhadap penerimaan usaha budidaya rumput laut. Nilai $R-C$ Ratio pada usaha budidaya rumput laut adalah sebesar 3,02 angka ini menunjukan usaha budidaya rumput laut dapat dikembangkan karena nilai $\mathrm{R} / \mathrm{C}>1$ yang artinya dalam 1 rupiah yang dikeluarkan bisa memberikan penerimaan sebesar 3,02 rupiah

\section{Analisis Break Event Point (BEP)}

Analisis ini digunakan untuk menentukan nilai titik impas dari suatu penjualan agar suatu perusahaan tidak untung dan tidak rugi. Analisis ini dapat dihitung berdasarkan perbandingan antara biaya variabel, biaya tetap dan penerimaan total selama 1 tahun produksi budidaya rumput laut. Hasil perhitungan BEP pada usaha budidaya rumput laut menunjukkan hasil Rp. 4.385.799,-- yang berarti usaha budidaya rumput laut akan mencapai titik impas jika dapat penerimaan sebesar Rp. 4.385.799,-- 


\section{Analisis Payback Period (PP)}

Perhitungan PP pada usaha budidaya rumput laut di Pulau Pari menunjukkan hasil 4,08 bulan atau sekitar 4 bulan, 8 hari yang berarti investasi yang ditanam pada usaha budidaya rumput laut akan kembali setelah jangka waktu 4 bulan 8 hari.

\section{Analisis Return of Investement (ROI)}

Analisis ini untuk mengetahui beberapa prosentase kemungkinan pengembalian keuntungan dari investasi yang ditanamkan dengan asumsi pendapatan setiap bulan atau tahun tetap. Nilai ROI untuk usaha budidaya rumput laut yaitu sebesar $1,2 \%$ dari investasi yang ditanamkan pada usaha budidaya rumput laut di Pulau Pari.

\section{Analisis Kriteria Investasi Net Present Value (NPV)}

Perhitungan nilai NPV pada perhitungan analisis kriteria investasi memperoleh nilai NPV sebesar Rp. 30.619.928,-artinya investasi awal tahun ke 0 usaha mendapatkan hasil Rp. 3.281 .500 pada tahun ke 5 akan memperoleh hasil sebesar Rp. 30.619.928,- hal ini menunjukkan usaha budidaya rumput laut layak untuk dijalankan.

\section{Net Benefit Cost Ratio (Net B/C)}

Nilai Net B/C pada usaha budidaya rumput laut merupakan analisis yang masih dalam keadaan kotor, dengan analisis ini dapat melihat kelayakan usaha. Nilai benefit kotor sebesar Rp. 50.648.130 dibagi dengan cost kotor sebesar Rp. 20.028.202 yang dapat diperoleh nilai $\mathrm{Net} B / \mathrm{C}$ yaitu sebesar 2,529. Hal ini menunjukkan kontribusi manfaat bersih selama terhadap biaya selama umur proyek 5 tahun dengan suku bunga $13 \%$.

\section{Internal Rate of Return (IRR)}

Perhitungan IRR dilakukan untuk mengetahui besarnya tingkat suku bunga yang dapat menyebabkan nilai NPV bernilai nol. Berdasarkan perhitungan nilai IRR dengan tingkat suku bunga 13\% mendapatkan hasil sebesar 89,23\%yang artinya usaha budidaya rumput laut dapat menyebabkan nilai NPV bernilai nol pada tingkat suku bunga $89,23 \%$. Hal ini menunjukkan usaha budidaya rumput laut layak untuk dijalankan 


\section{Kesimpulan}

Hasil dari pengamatan dan analisis usaha budidaya rumput laut Eucheuma cottonii dapat disimpulkan sebagai berikut:

1) Budidaya rumput laut di Pulau Pari Kepulauan Seribu perlu dikembangkan kembali, sebab dilihat dari penelitian ini perkembangan rumput laut terlihat baik sampai dengan hasil panen yang mencapai $600 \mathrm{Kg}$ dari bibit 67,5 kg.

2) Hasil dari analisis usaha yang dilakukan penulis menujukan hasil yang baik dan bisa dikembangkan lagi usaha rumput laut ini. Terdapat penerimaan pertahun yang diperoleh sebesar Rp. 14.400.000,- dengan keuntungan yang diterima nelayan pertahun sebesar Rp. 9.638.668,-- Nilai R/C yang diperoleh adalah 3,02, dengan angka ini menujukkan usaha dapat dikembangkan karena ini $\mathrm{R} / \mathrm{C}>1$. Nilai BEP adalah Rp. 4.385.799,-. Nilai ROI sebesar 1,2\% yang berarti presentase nilai keuntungan yang diperoleh dari jumlah yang diinvestasikan dalam jangka satu tahun. Nilai PP yang diperoleh sebesar 4,08 bulan angka ini menunjukkan bahwa dana investasi yang dikeluarkan akan kembali dalam jangka waktu 4 bulan 8 hari.

3) Hasil analisis usaha kriteria investasi dengan cara menghitung nilai NPV, Net B/C dan IRR yang akan menunjukkan suatu usaha budidaya rumput laut layak atau tidak untuk dijalankan. Dari nilai NPV pada tahun ke 5 mendapatkan hasil Rp. 30.619.928. Nilai Net B/C bernilai 2,529 hal ini menunjukkan kontribusi manfaat bersih terhadap biaya selama umur proyek 5 tahun dengan tingkat suku bunga 13\%. Berdasarkan perhitungan nilai IRR pada tingkat suku bunga $13 \%$ yang menyebabkan nilai NPV bernilai nol pada tingkat suku bunga sebesar 89,23\%. .

\section{Saran}

Saran pada penelitian ini pada usaha budidaya rumput laut Eucheuma cottonii di Pulau Pari Kepulauan Seribu perlu dikembangkan kembali, serta peran dari intasi pemerintahan mengenai perkembangan budidaya rumput laut perlu diperhatikan lagi, karena dilihat dari segi analisis usaha budiaya rumput laut sangat membantu juga untuk perekonomian para nelayan di Pulau Pari

\section{Ucapan Terimakasih}

Ucapan terimakasih kepada Bapak Dr. Ir. Edward Danakusumah.M.Sc dan Ibu Dr. Ir. Urip Rahmani.M.Si selaku dosen pembimbing. Ibu Dr. Ir. Dwi Ernaningsih. M.Si selaku Dekan FPIK yang memberikan petunjuk, arahan dan bimbingan demi kesuksesan penulis.Serta kedua orang tua, keluarga besar dan kawan-kawan yang selalu memberikan doa dan motivasi dalam penulisan ini. 


\section{DAFTAR PUSTAKA}

Anggadiredja Jana, T.A. Zatnika, H, Purwoto dan Sri Istini. 2011. Rumput Laut (Pembudidayaan, Pengolahan dan Pemasaran Komoditi Perikanan Potensial). Penebar Swadaya. Jakarta.

Djamin, Z. 1993. Perencanaan dan Analisa Proyek.Fakultas Ekonomi Universitas Indonesia. Jakarta.

Hernanto F. 1989. Ilmu Usaha Tani. Cetakan ke-7.Jakarta.: Penebar Swadaya. 309 hal.

Khordi, M dan Ghufran H. 2010.A to Z Budidaya Biota Akuatik untuk Pangan, Kosmetik dan Obat-obatan. Andi Offset. Yogyakarta.

Rahardi, R. Kristiawati dan Nazarudin. 1993. Agribisnis Perikanan. Jakarta: Penebar Swadaya. 


\title{
KAJIAN STOK IKAN PELAGIS KECIL DENGAN ALAT TANGKAP MINI PURSE SEINE DI PERAIRAN LEMPASING, LAMPUNG
}

\author{
Riena F. Telussa
}

1 Fakultas Perikanan dan IImu Kelautan, Universitas Satya Negara Indonesia

\begin{abstract}
Pelagic fish resources are the fish resources that lives in the sea or in the surface waters and generally consists of small fish such as mackerel (Rastrelliger spp.), Trevally fish (Selaroides spp.) Kite (Decapterus spp.) And many others. Small pelagic fish have high economic value and so many people who consume it. These conditions have encouraged fishermen to catch as many fish as possible even to the level of exploitation before preceded by fishing or other fishing companies. When used to over-exploitation level, these resources will be disrupted continuity and can eventually lead to extinction. Therefore any area used for fishing effort needs to know the number of potential existing in this waters in order to fish resources remain sustainable it is necessary to study the magnitude of the stock of fish. Fisheries stock assessment aims to optimally exploit aquatic resources, which means also an effort to raise the level of utilization in the long term provide maximum catches in the form of weights.

Data analysis of catch and fishing effort include the catch per unit effort (CPUE), the potential for sustainable (MSY) and $f$ OPT. Resource utilization rate can be calculated using the analysis method with the application of surplus production Schaefer method. CPUE values occurred in 2008 at 9.23 tons per unit but the highest catches in 2011 amounted to 2.355.31 tons, while the highest fishing effort occurred in 2011 amounted to 457 units. The smallest value of CPUE occurred in 2005 at 4.01 tons per unit, as well as catches the smallest occurred in 2005 amounted to 657.75 tons and the smallest fishing effort occurred in 2006 amounted to 145 units.

Application of the method surplus production, optimum effort values obtained with the first derivative of the equation of the relationship between CPUE and fishing effort. Optimum Effort Values obtained by 756.02 units per year. MSY values obtained during the period 2005-2011 amounted to 3.187.25 tons per year. While the rate of utilization of small pelagic fish in the waters of the highest Lempasing occurred in 2011 amounted to $73.90 \%$ and the lowest occurred in 2005 was $20.64 \%$, with an average value of $49.42 \%$ per year. Of the value of the average utilization rate of $49.42 \%$ and by MSY 3.187 .25 tons per year during the years 2005-2011 were obtained indicating that the use of small pelagic fish annually will increase but not exceed MSY, but if it is associated with a number of catches allowed (JTB) ie $80 \%$ of the MSY (2.549.80 tons per year) and is nearing MSY, with optimum effort of 756.02 units per year, shows that the insistence on small pelagic fish in the waters of the Sea Lempasing not exceed fopt.

By using the method of Schaefer obtained a relationship between fishing effort and catch per unit of fishing effort by the regression equation, the value of the intercept $(a)=$ 8.431, slope $(b)=-0.005$ and $R 2=0.099$
\end{abstract}

Keyword: catches, analysis of catch, method surplus production 


\begin{abstract}
Abstrak
Sumberdaya ikan pelagis merupakan sumberdaya ikan yang hidupnya di permukaan laut ataupun di permukaan perairan dan umumnya terdiri atas ikan yang berukuran kecil seperti ikan kembung (Rastrelliger spp.), selar (Selaroides spp.) layang (Decapterus spp.) dan masih banyak lagi lainnya. Ikan pelagis kecil mempunyai nilai ekonomis tinggi dan sangat banyak orang yang mengkonsumsinya. Kondisi tersebut telah mendorong nelayan untuk menangkap ikan sebanyak mungkin bahkan sampai tingkat eksploitasi berlebihan sebelum didahului oleh nelayan atau perusahaan perikanan yang lainnya. Apabila dimanfaatkan sampai tingkat eksploitasi berlebihan, sumberdaya tersebut akan terganggu kelestariannya dan akhirnya dapat mengakibatkan kepunahan. Oleh karena itu setiap wilayah yang dimanfaatkan untuk usaha penangkapan ikan perlu diketahui jumlah potensinya yang ada di perairan tersebut agar sumberdaya ikan tetap lestari maka perlu dilakukan pengkajian besarnya stok sumberdaya ikan tersebut. Pengkajian stok sumberdaya perikanan bertujuan untuk memanfaatkan sumberdaya perairan secara optimal, yang berarti pula sebagai upaya peningkatan tingkat pemanfaatan dalam jangka panjang yang memberikan hasil tangkapan yang maksimal dalam bentuk bobot.

Analisis data hasil tangkapan dan upaya penangkapan meliputi catch per unit effort (CPUE), potensi lestari (MSY) dan fopt. Tingkat pemanfaatan sumberdayanya dapat dihitung menggunakan analisis metode surplus produksi dengan penerapan metode Schaefer. Nilai CPUE terbesar terjadi pada tahun 2008 sebesar 9,23 ton per unit namun hasil tangkapan tertinggi terjadi pada tahun 2011 sebesar 2.355,31 ton, sedangkan upaya penangkapan tertinggi terjadi pada tahun 2011 sebesar 457 unit. Nilai CPUE terkecil terjadi pada tahun 2005 sebesar 4,01 ton per unit, demikian pula hasil tangkapan terkecil terjadi pada tahun 2005 sebesar 657,75 ton dan upaya penangkapan terkecil terjadi pada tahun 2006 sebesar 145 unit.

Penerapan metode surplus produksi, didapatkan nilai effort optimum dengan turunan pertama dari persamaan hubungan antara CPUE dan upaya penangkapan. Nilai Effort optimum didapatkan sebesar 756,02 unit per tahun. Nilai MSY yang didapatkan selama kurun waktu 2005-2011 sebesar 3.187,25 ton per tahun. Sedangkan Tingkat Pemanfaatan ikan pelagis kecil di perairan Lempasing tertinggi terjadi pada tahun 2011 sebesar $73,90 \%$ dan terendah terjadi pada tahun 2005 sebesar $20,64 \%$, dengan nilai rata-rata pertahunnya sebesar 49,42\%. Dari nilai tingkat pemanfaatan rata-rata 49,42\% dan nilai MSY 3187,25 ton per tahun yang didapatkan selama tahun 2005-2011 mengindikasikan bahwa pemanfaatan ikan pelagis kecil setiap tahunnya meningkat akan tetapi belum melebihi nilai MSY, namun apabila dikaitkan dengan jumlah tangkapan yang diperbolehkan (JTB) yaitu $80 \%$ dari nilai MSY (2.549,80 ton per tahun) dan hampir mendekati nilai MSY, dengan nilai effort optimum 756,02 unit per tahun, menunjukan bahwa pengupayaan ikan pelagis kecil di perairan Laut Lempasing belum melebihi fopt.

Dengan menggunakan metode Schaefer diperoleh hubungan antara upaya penangkapan dan hasil tangkapan per satuan upaya penangkapan dengan persamaan regresi, nilai intersep $(a)=8,431$, slop $(b)=-0,005$ dan $R^{2}=0,099$.
\end{abstract}

Kata Kunci: Hasil Tangkapan, Analisis Hasil Tangkapan, Metode Surplus Produksi 


\section{Pendahuluan}

Secara umum perikanan Indonesia bersifat terbuka (open access), dimana nelayan dapat dengan bebas melakukan usaha penangkapan ikan di laut. Kondisi yang demikian telah mendorong nelayan untuk menangkap ikan sebanyak mungkin sebelum didahului oleh nelayan atau perusahaan perikanan yang lainnya. Sumberdaya perikanan termasuk kedalam sumberdaya yang memiliki kemampuan untuk dapat memperbaharui dirinya (renewable), namun apabila dimanfaatkan sampai tingkat eksploitasi berlebihan, sumberdaya tersebut akan terganggu kelestariannya dan akhirnya dapat mengakibatkan kepunahan. Sektor perikanan memberikan konstribusi terhadap pembangunan nasional berupa penyediaan bahan pangan bergizi tinggi, memenuhi kebutuhan protein hewani masyarakat, lapangan perkerjaan, aktifitas perekonomian dan ikut berperan dalam menunjang keberhasilan pembangunan yang berkelanjutan. Pemanfaatan potensi sumberdaya harus dilakukan secara terkontrol, sehingga kelestarian sumberdaya ikan di setiap wilayah perairan senantiasa dapat dipertahankan agar produktifitas optimum dapat terjaga. Oleh karena itu setiap wilayah yang dimanfaatkan untuk usaha penangkapan ikan perlu diketahui jumlah potensinya yang ada di perairan tersebut agar sumberdaya ikan tetap lestari maka perlu dilakukan pengkajian besarnya stok sumberdaya ikan tersebut.

Pengkajian stok sumberdaya perikanan bertujuan untuk memanfaatkan sumberdaya perairan secara optimal, yang berarti pula sebagai upaya peningkatan tingkat pemanfaatan dalam jangka panjang yang memberikan hasil tangkapan yang maksimal dalam bentuk bobot. Pengkajian stok dilakukan dengan mengendalikan intensitas penangkapan hingga tercapainya pengusahaan yang secara ekonomi menguntungkan. Upaya pengkajian stok sudah lama dan banyak diterapkan dalam bentuk survei lapangan dan analisis data perikanan yang ada. Pengkajian dengan analisis data dilakukan dengan menggunakan model surplus produksi, dimana pengkajian diasumsikan dengan perhitungan stok tunggal dan upaya penangkapan tunggal.

Sumberdaya ikan pelagis merupakan sumberdaya ikan yang hidupnya di permukaan laut ataupun di permukaan perairan dan umumnya terdiri atas ikan yang berukuran kecil seperti ikan kembung (Rastrelliger spp.), selar (Selaroides spp.) layang (Decapterus spp.) dan masih banyak lagi lainnya. (Amin dalam Tiennansari, 2000). ikan-ikan pelagis kecil mempunyai karakteristik tertentu dalam penyebarannya. pada malam hari ikan-ikan pelagis kecil menyebar merata pada kolam perairan dan lebih dekat ke permukaan, sedangkan pada siang harinya ikan ini berada pada kedalaman tertentu yang merupakan batas aman dari lapisan renang (swimming layers) dari pergerakan ikan. Hal-hal yang menyebabkan ikan membentuk gerombolan antara lain adalah (1) sebagai perlindungan diri dari pemangsa atau predator, (2) mencari dan menangkap mangsa, (3) memijah, (4) musim dingin (5) ruaya dan pergerakan (6) pengaruh fakor lingkungan Gunarso (1985)

Salah satu kegiatan perikanan tangkap di Propinsi Lampung adalah perairan Lempasing, daerah ini terletak di wilayah Selatan Sumatera dari Bengkulu serta berhubungan langsung dengan Samudra Hindia. Hasil tangkapan sumberdaya ikan pelagis kecil yang didaratkan di Teluk Lampung sangat banyak dan beragam jenis Ikan yang banyak didaratkan di PPI Lempasing terdiri dari berbagai jenis ikan, diantaranya adalah kembung (Rastrelliger spp.), layang (Decapterus spp.), teri (Stolephorus spp.), selar (Selaroides spp.), dan lemuru (Sardinella longiceps). dan masih banyak jenis ikan lainnya. Ikan selar (Selaroides spp.) dan ikan layang (Decapterus spp.) merupakan ikan pelagis kecil dan termasuk salah satu jenis ikan yang mempunyai nilai ekonomis penting. Melihat kondisi tersebut maka penelitian mengenai kajian stok ikan pelagis kecil dengan alat tangkap mini purse seine di perairan Lempasing, Lampung perlu dilakukan. Penelitian ini dilakukan untuk mengetahui tingkat pemanfaatan ikan dan kecenderungan perkembangan hasil tangkapan ikan pelagis kecil di PPP Lempasing. 


\section{Metodelogi Penelitian}

Penelitian ini dilaksanakan bersama Kantor Balai Penelitian Perikanan Laut Muara Baru Jakarta utara pada bulan September-Desember 2013 yang bertempat di Pelabuhan Perikanan Pantai Lempasing (PPP) Kota Bandar Lampung-Sumatra selatan Data yang di kaji dalam penelitian berupa data primer yang diperoleh dengan cara monitoring, serta data sekunder yang diperoleh dengan cara wawancara. Seluruh data yang diperoleh ditabulasi dan diolah untuk mencapai tujuan penelitian. Analisis data hasil tangkapan dan upaya penangkapan meliputi catch per unit effort (CPUE) dan metode surplus produksi (potensi lestari (MSY) dan fopt).

Perhitungan CPUE bertujuan untuk mengetahui kelimpahan dan tingkat pemanfaatan ikan yang didasari atas pembagian total hasil tangkapan (catch) dengan upaya penangkapan (effort). Menurut Gulland (1983), rumus yang digunakan adalah sebagai berikut:

\section{CPUE}

Dimana:

Catch : Total hasil tangkapan (ton)

Effort : Total upaya penangkapan (trip)

CPUE : Hasil tangkapan per upaya penangkapan (ton/trip)

Pendugaan upaya penangkapan optimum $\left(f_{\text {opt }}\right)$ dan hasil tangkapan maksimum yang lestari (MSY) dapat dihitung dengan model Schaefer (Pauly, 1984). Gulland (1983), menyatakan bahwa hubungan antara hasil tangkapan per satuan upaya (CPUE) dan upaya (effort) dapat berupa hubungan linear maupun eksponensial.

Menurut Schaefer dalam Handoyo, (1991), hubungan effort dan catch menghasilkan kurva yang berbentuk parabola yang simetris. Formula yang disajikan adalah:

1. Hubungan antara CPUE dengan Upaya Penangkapan (f)

2. Hubungan antara hasil tangkapan (c) dan upaya penangkapan (f)

(c)

3. Effort optimum diperoleh dari turunan persamaan ke dua (2) sama dengan nol (0) yaitu:

(c)

4. Produksi maksimum lestari (MSY) diperoleh dengan mensubsitusikan nilai effort optimum ke dalam persamaan ke dua (2) yaitu: 
(c)

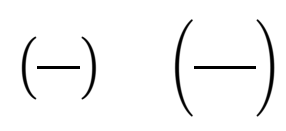

Dimana:

$\mathrm{a}=$ intercep

$\mathrm{b}=$ slop

$\mathrm{f}=$ upaya penangkapan (unit)

$\mathrm{c}=$ hasil tangkapan (catch)

Langkah-langkah untuk menghitung CPUE dengan menggunakan rumus metode Schaefer sebagai berikut:

a) Membuat tabel data catch (c) dan upaya penangkapan (f) serta menghitung CPUE

b) Memplotkan nilai CPUE terhadap nilai $f$ yang bersangkutan dan menghitung intersep (a) dan gradien (b) dengan menggunakan teknik linear.

c) Menghitung $\mathrm{f}_{\text {optimum }}$

d) Menghitung Maksimum Sustainable Yield (MSY)

Selanjutnya untuk menghitung tingkat pemanfaatan ikan digunakan persen jumlah hasil tangkapan pada tahun tertentu dengan nilai produksi maksimum lestari (MSY), yaitu:

Tingkat Pemanfaatan $=$

Dimana:

$\mathrm{Ci}=$ Jumlah tangkapan ikan pada tahun ke-i

MSY = Maksimum Sustainable Yield

Besarnya a dan b dapat dicari dengan menggunakan persamaan:

$$
\frac{\left(\sum X i\right)\left(\sum \quad i\right)}{\left(\sum \mathrm{i}\right)}
$$

Dimana:

$\mathrm{Xi}=$ Effort pada periode ke- $\mathrm{i}$

$\mathrm{Yi}=$ CPUE pada periode ke-i

$\mathrm{n}$ = Jumlah tahun

\section{Hasil dan Pembahasan}

Hasil survey dan observasi yang dilakukan selama penelitian mengenai kajian stok ikan pelagis kecil dengan alat tangkap mini purse seine di perairan Lempasing Lampung diperoleh data sebagai berikut: 


\section{Hasil Tangkapan}

Hasil tangkapan ikan pelagis kecil yang didaratkan di PPP Lempasing dalam kurun waktu 7 tahun yaitu, tahun 2005-2011 mengalami fluktuasi yang signifikan setiap tahunnya dapat dilihat pada Gambar 1.

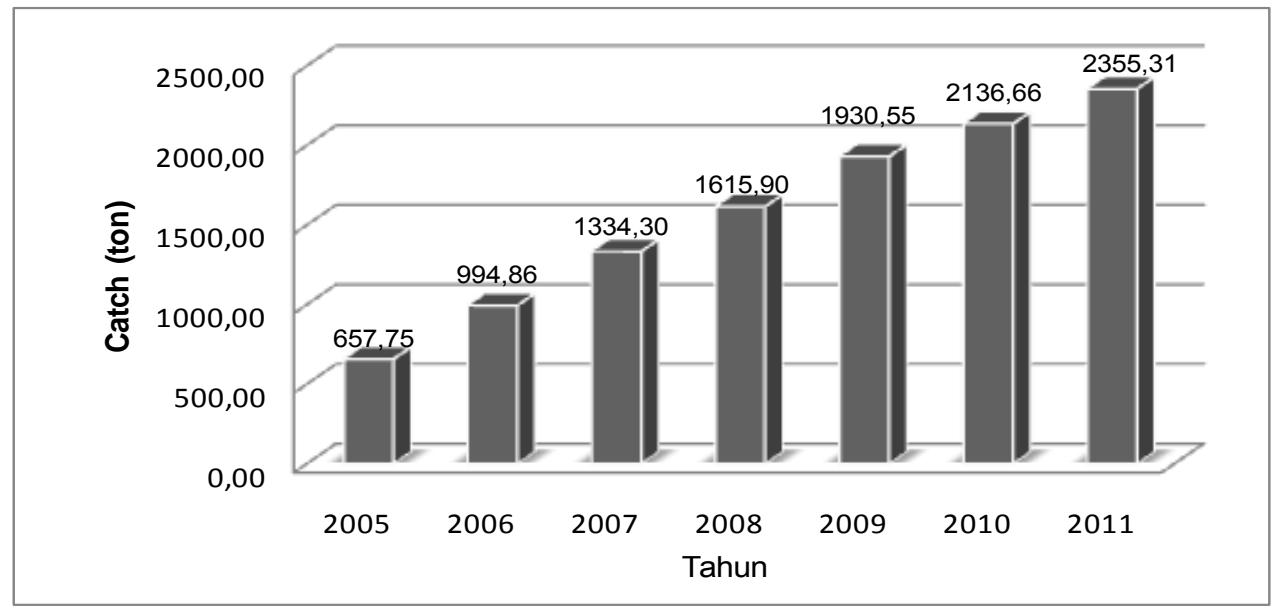

Gambar 1. Fluktuasi Hasil Tangkapan Ikan yang Didaratkan di PPP Lempasing Tahun 20052011

Hasil tangkapan pada tahun 2005 sebesar 657,75 ton tahun 2006 hasil tangkapan meningkat menjadi 998,86 ton, tahun 2007 meningkat lagi menjadi 1334,30 ton, tahun 2008 terus meningkat menjadi 1615,90 ton, tahun 2009 meningkat lagi menjadi 1930,55, tahun 2010 meningkat terus menjadi 2136,66 ton dan tahun 2011 meningkat kembali menjadi 2355,31 ton. Hasil tangkapan pada tahun 2005 merupakan hasil tangkapan terendah dalam kurun waktu tujuh tahun terakhir sedangkan hasil tangkapan pada tahun 2011 merupakan hasil tangkapan tertinggi. Hasil tangkapan tinggi yang terjadi selama tiga tahun terakhir yaitu pada tahun 2009-2011 diduga ikan pelagis kecil yang ada di perairan Lempasing pada saat itu berlimpah.

\section{Upaya Penangkapan}

Upaya (unit) penangkapan ikan pelagis kecil dalam kurun waktu 7 tahun yaitu, dari tahun 2005-2011 mengalami fluktuasi yang signifikan. setiap tahunnya dapat dilihat pada Gambar 2.

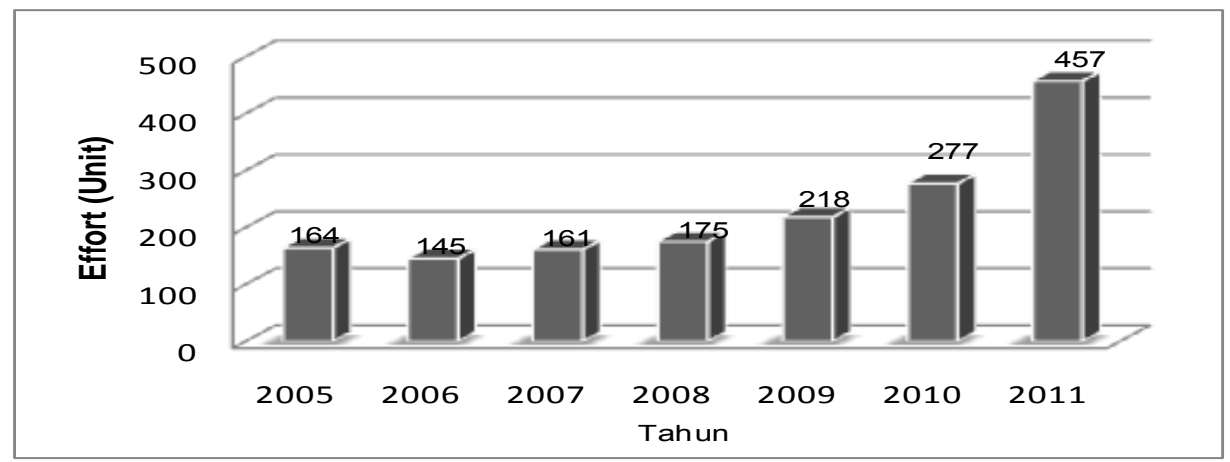

Gambar 5. Fluktuasi Upaya Penangkapan Ikan yang Didaratkan di PPP Lempasing Tahun 2005-2011 
Upaya penangkapan pada tahun 2005 sebanyak 164 unit, tahun 2006 upaya penangkapan mengalami penurunan menjadi 145 unit, tahun berikutnya 2007 unit penangkapan mengalami peningkatan menjadi 161 unit dan pada tahun 2008 upaya penangkapan meningkat menjadi 175 unit dan pada tahun 2009 upaya penangkapan meningkat menjadi 218 unit dan pada tahun 2010 upaya penangkapan meningkat lagi menjadi 277 unit. Upaya penangkapan tertinggi terjadi pada tahun 2011 yaitu sebesar 457 unit dan upaya penangkapan terendah terjadi pada tahun 2006 sebesar 145 unit. Peningkatan upaya penangkapan pada tahun 2010 dan 2011 disebabkan karena harga ikan di pasar pada saat itu tinggi dan juga karena cuaca yang mendukung, jadi para nelayan setempat banyak yang melakukan operasi penangkapan. Selain itu, juga didukung dengan keadaan perairan yang subur yang diakibatkan oleh proses upwelling sehingga di perairan tersebut banyak makanan bagi ikan. Sudah menjadi ketentuan bahwa sifat ikan beruaya dan migrasi ke perairan yang kaya akan makanannya

\section{Hasil Tangkapan Per Satuan Upaya Penangkapan}

Hasil tangkapan per satuan upaya penangkapan atau Catch Per Unit Effort (CPUE) sangat penting dalam pengawasan dan pengendalian penangkapan. Dalam sumberdaya perikanan penghitungan CPUE bertujuan untuk mengetahui tingkat pemanfaatan ikan dan kecenderung perkembangan hasil tangkapan ikan yang didaratkan di PPP Lempasing. Nilai hasil tangkapan per satuan upaya penangkapan ikan pelagis kecil yang didaratkan di PPP Lempasing tahun 2005-2011 disajikan pada Gambar 3.

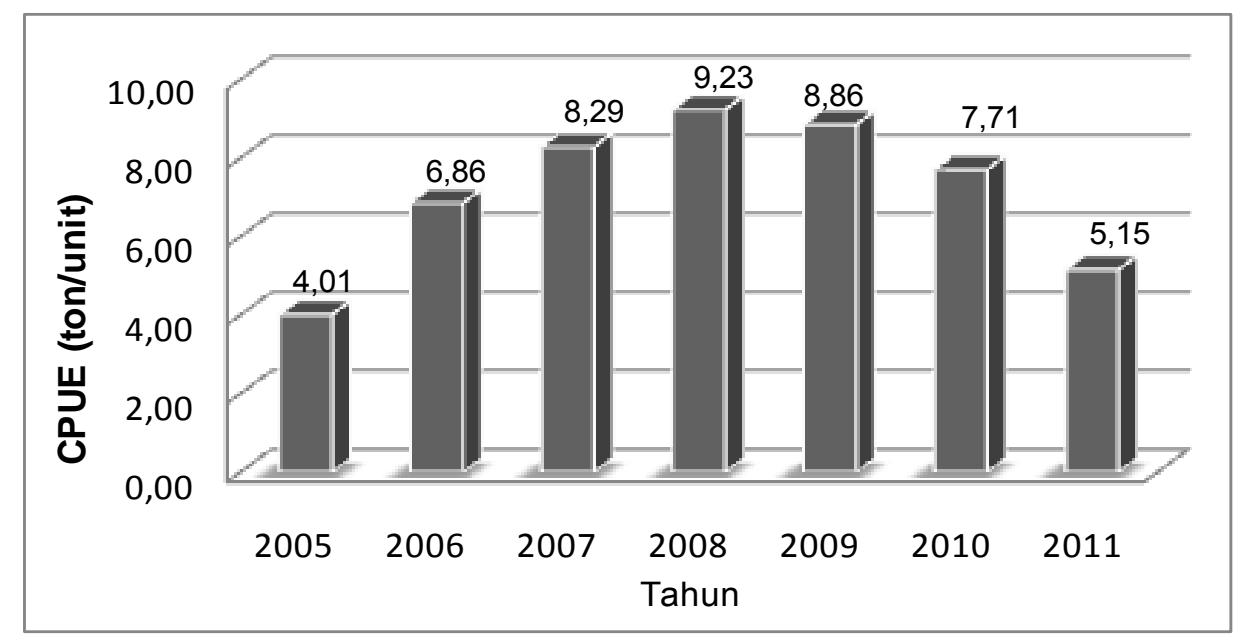

Gambar 3. Fluktuasi Catch Per Unit Effort (CPUE) di PPP Lempasing Tahun 2005-2011

Gambar 3 menunjukan bahwa nilai CPUE selama tahun 2005-2011 mengalami fluktuasi yang cukup signifikan. Nilai CPUE yang terjadi pada tahun 2005 sebesar 4,01 ton/unit, pada tahun 2006 meningkat menjadi 6,86 ton/unit, pada tahun 2007 meningkat lagi menjadi 8,29 ton/unit, dan pada tahun 2008 meningkat terus menjadi 9,23 ton/unit, untuk tahun selanjutnya mengalami penurunan menjadi 8,86 ton/unit pada tahun 2009 , pada tahun 2010 menurun kembali menjadi 7,71 ton/unit dan pada tahun 2011 mengalami penuruna lagi menjadi 5,51 ton/unit. Untuk nilai CPUE tertinggi terdapat pada tahun 2008 sebesar 9,23. Hal ini berarti , penaikan upaya penangkapan tidak akan selalu menaikan nilai CPUE, bahkan sebaliknya. Sesuai dengan pernyatan Genisa (1998) bahwa tingkat pengupayaan yang tinggi menurunkan nilai CPUE artinya, tingkat pengupayaan berbanding terbalik dengan nilai CPUE, dan juga sesuai dengan pernyataan Ali (2005) bahwa penambahan upaya penangkapan tidak dapat lagi meningkatkan nilai CPUE atau penambahan upaya selalu diikuti dengan penurunan nilai CPUE. 
Penurunan nilai CPUE yang disebabkan karena penaikan upaya penangkapan, juga berpengaruh terhadap hubungan antara Cacth, dengan mengaikan antara Effort dan Cacth kita bisa mengetahui trend fluktuasinya. Hubungan antara CPUE dengan Effort disajikan pada Gambar 4. Terlihat bahwa upaya penangkapan meningkat secara signifikan yang terjadi pada tahun 2011 dan diikuti dengan penurunan nilai CPUE. Dengan persamaan regresi yang diperoleh adalah nilai Intersep $(a)=8,431$, slop $(b)=-0,005$ dan nilai $R^{2}$ $=0,099$

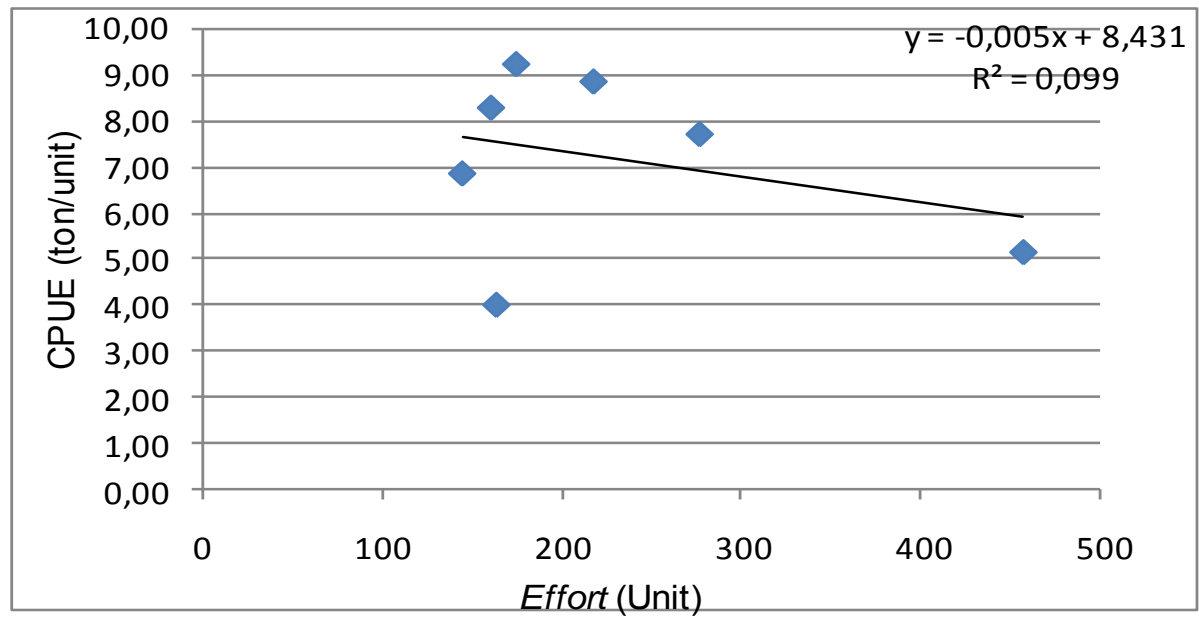

Gambar 4.. Grafik Hubungan antara CPUE dan Effort.

4. Metode Surplus Produksi

Model surplus produksi digunakan untuk mengetahui atau mengkaji potensi lestari dan tingkat pemanfaatan sumber daya perikanan dalam suatu perairan. Yang mana dalam Model Produksi Surplus ini digunakan metode Schafer untuk mencari potensi lestari (MSY), fopt dan tingkat pemanfaatan.

\section{Maximum Sustainable Yield (MSY)}

Hasil tangkapan maksimum lestari adalah besarnnya jumlah ikan yang dapat ditangkap secara terus menerus dari suatu sumberdaya tanpa mempengaruhi kelestarian stok ikan. Hal ini dapat juga digunakan untuk menduga fluktuasi kelimpahan suatu jenis ikan dan menggambarkan biomassa ikan-ikan di suatu perairan.

Nilai potensi lestari yang diperoleh dari perhitungan nilai CPUE selama periode 20052011 adalah sebesar 3187,25 ton per tahun. Grafik hubungan antara Catch dan effort tersebut seperti terlihat pada Gambar 4. yang juga menunjukan nilai effort optimum sebesar 756,02 unit per tahun. Dengan menggambarkan model surplus produksi untuk hubungan antara upaya penangkapan (effort) dengan hasil tangkapan per satuan upaya penangkapan (CPUE) diperoleh potensi lestari maksimum (MSY) ikan sebesar 3187,25 ton per tahun. Potens lestari maksimum merupakan suatu nilai batas dimana sumberdaya ikan yang dapat dimanfaatkan tanpa mengganggu kelestarian untuk tumbuh dan menjaga keturunannya. Upaya penangkapan optimum (fopt) adalah besarnya upaya penangkapan yang dilakukan oleh unit penangkapan, agar mendapatkan hasil yang maksimal, tanpa merusak kelestarian sumberdaya yang ada. 


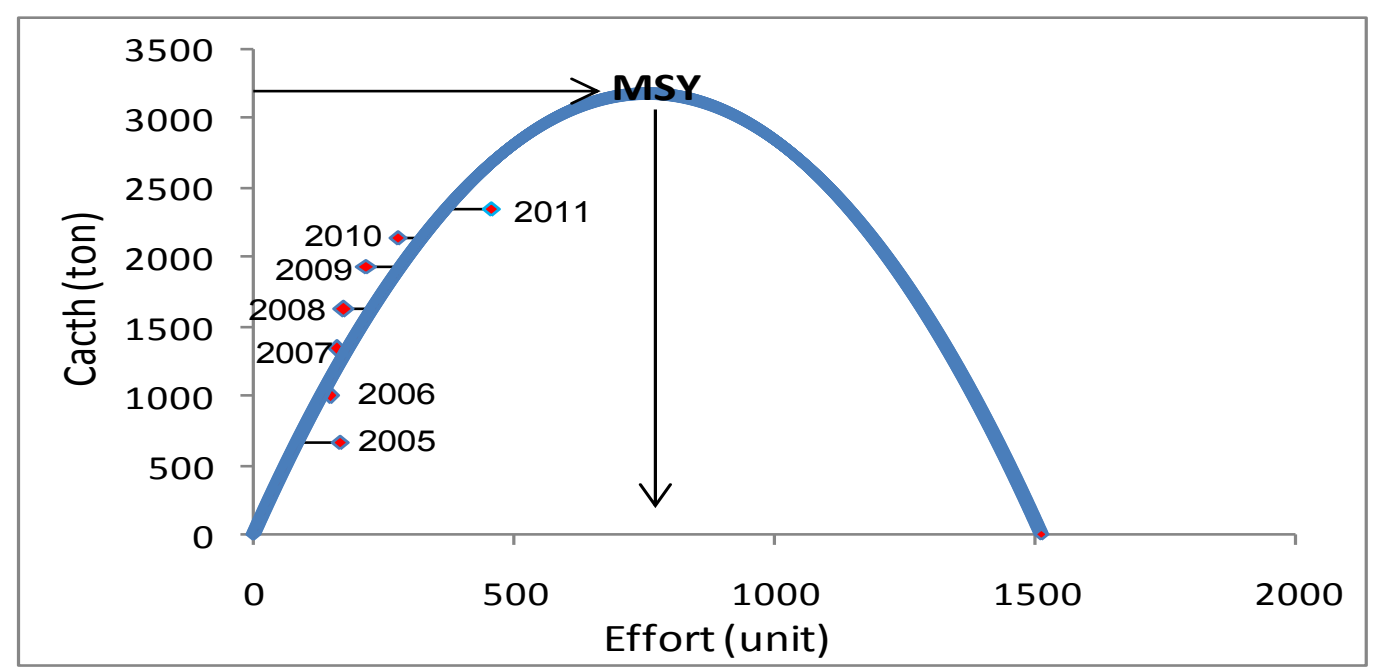

Gambar 5. Grafik Hubungan Catch dan Effort Ikan Selama Tahun 2005-2011 di PPP Lempasing.

Gambar 5 diketahui bahwa hubungan antara upaya penangkapan (effort) dengan produksi ikan (catch). Artinya dengan menambahkan effort 756,02 unit per tahun maka akan meningkatkan produksi maksimal sampai 3187,25 ton per tahun. Sehingga untuk pemanfaatan sumberdaya ikan secara berkelanjutan maka upaya penangkapan tidak boleh melebihi 756,02 unit per tahun dengan produksi maksimal lestari (MSY) 3187,25 ton per tahun. Kurva hubungan antara cath dan effort menunjukan bahwa pada tahun 2005, dan 2006 produksi hasil tangkapan belum melebihi MSY dengan upaya dibawah fopt, pada tahun 2007-2010 produksi hasil tangkapan meningkat dan berada di luar kurva MSY yang artinya produksi pada tahun 2007-2010 tidak sustainable, akan tetapi belum melebihi MSY dan pada tahun 2011 produksi hasil tangkapan meningkat dengan diikuti meningkatnya upaya penangkapan akan tetapi belum melebihi MSY dan fopt. Dari uraian Gambar 5 dapat kita ketahui bahwa produksi hasil tangkapan ikan selama 7 tahun terakhir 2005-2011 belum melebihi MSY dan upaya penangkapannya juga belum melebihi fopt jadi dapat dikatakan jumlah ikan yang ada di perairan Lempasing masih banyak dan berlimpah. Akan tetapi untuk menjaga keletariannya perlu adanya pengawasan dan pengontrolan yang bijaksana agar kelestariannya dapat terjaga terus.

\section{Tingkat Pemanfaatan}

Adanya nilai MSY untuk sumberdaya ikan dapat dimanfaatkan untuk mengetahui tingkat pemanfaatan sumberdaya tersebut. Tingkat pemanfaatan menunjukan kemampuan dalam memanfaatkan sumberdaya perikanan yang ada. Tingkat pemanfaatan merupakan kemampuan nelayan Lempasing untuk memanfaatkan sumberdaya ikan yang tersedia di perairan Lempasing. Tabel 1 menunjukan tingkat pemanfaatan yang tinggi pada tahun 2011 sebesar 73,90 \% dan tingkat pemanfaatan terendah terjadi pada tahun 2005 sebesar 20,26 \%. Tingkat pemanfaatan ikan pada tahun 2006-2011 cukup berfluktuasi, yang pada umumnya meningkat terus. 
Tabel 1. Tingkat Pemanfaatan Ikan di Perairan Lempasing Selama Tahun 2006-2011.

\begin{tabular}{|l|l|l|}
\hline Tahun & Catch (ton) & Tingkat Pemanfaatan (\%) \\
\hline 2005 & 657,75 & 20,64 \\
\hline 2006 & 994,86 & 31,21 \\
\hline 2007 & 1334,30 & 41,86 \\
\hline 2008 & 1615,90 & 50,70 \\
\hline 2009 & 1930,55 & 60,57 \\
\hline 2010 & 2136,66 & 67,04 \\
\hline 2011 & 2355,31 & 73,90 \\
\hline Rata-rata & 49,42 \\
\hline
\end{tabular}

Berdasarkan rata-rata tingkat pemanfaatan sebesar $49,42 \%$ per tahunnya dapat dikatakan bahwa tingkat pemanfaatan sumberdaya ikan di perairan Lempasing oleh nelayan setempat setiap tahunnya meningkat akan tetapi belum melebihi nilai MSY, namun apabila dikaitkan dengan jumlah tangkapan yang diperbolehkan (JTB) yaitu $80 \%$ dari nilai MSY (2549,80 ton per tahun) dan hampir mendekati nilai MSY. Oleh karena itu perlu ke hati-hatian dalam pemanfaatannya karena tanpa ada pengontrolan dan pengawasan akan mengakibatkan over fishing dan produksi yang berlebihan yang akibatnya populasi ikan yang ada di perairan Lempasing terancam kelestariannya.

Upaya pengelolaan sumberdaya ikan dapat dilakukan melalui pengaturan upaya penangkapan baik berupa jumlah trip maupun jumlah alat tangkap yang digunakan dalam mengeksploitasi serta pengaturan kuota penangkapan, untuk menghindari over exploitasi yang dapat menyebabkan overfishing secara biologi (biological overfishing) karena dapat melewati nilai maksimum lestari (MSY). Dimana menurut Widodo dan Suadi (2006), bahwa biological overfishing akan terjadi manakala tingkat upaya penangkapan dalam suatu perikanan tertentu telah melampaui tingkat yang diperlukan untuk menghasilkan potensi maksimum lestari (MSY), namun dapat dicegah dengan melakukan pengaturan upaya penangkapan dan pola penangkapan. 


\section{Kesimpulan}

1. Nilai hasil tangkapan per satuan upaya penangkapan di perairan Lempasing selama tahun 2005-2011 mengalami fluktuasi yang signifikan. Pada tahun 2005-2008 fluktuasi meningkat terus dan pada tahun 2009-2011 nilai hasil tangkapan per satuan penangkapan menurun. Nilai hasil tangkapan per satuan upaya penangkapan yang tertinggi terjadi pada tahun 2008 sebesar 9,23 ton/unit Hal ini berarti , penaikan upaya penangkapan tidak akan selalu menaikan nilai CPUE bahkan sebaliknya, dan nilai hasil tangkapan per satuan penangkapan yang terendah terjadi pada tahun 2005 sebesar 4,01 ton/unit. Selain faktor upaya, diduga peningkatan nilai CPUE pada tahun 2008 terkait dengan melimpahnya ikan di perairan Lempasing, sementara itu keadaan laut yang relatif tenang dan cuaca yang mendukung, sehingga proses penangkapan berjalan dengan lancar.

2. Terkait dengan potensi pemanfaatan ikan di perairan Lempasing, diperoleh nilai MSY 3187,25 ton per tahun dan upaya fopt 756,02 unit per tahun dan belum melebihi hasil produksi yang diperoleh dan upaya. Serta nilai MSY juga belum melebihi jumlah tangkapan yang diperbolehkan (JTB) yaitu $80 \%$ dari nilai MSY (2549,80 ton per tahun)

\section{DAFTAR PUSTAKA}

Ali, TH. 2005. Prinsip-prinsip Network Planning. Jakarta : PT Gramedia. 309 hal.

Amin, E.M. 1979. Suatu Analisa tentang Potensi Perairan di Selat Sunda. Lembaga Penelitian Perikanan Laut. No. PL 001/79. Jakarta. 19 hlm.

Genisa, A. S. 1998. Beberapa Catatan Tentang Alat Tangkap Ikan Pelagis Kecil. Balitbang Biologi Laut. Puslitbang Oseanologi-LIPI. Jakarta.

Gulland, JA. 1983. Fish Stock Assessment: a Manual of Basic Methods, volume 1.John Wiley \& Sons, inc. New York, USA. xii + 223 p.

Gunarso, W. 1985. Tingkah Laku Ikan. Bahan Pengajaran (tidak dipublikasikan). Fakultas Perikanan, Institut Pertanian Bogor, Bogor. 148 halaman.Tiennansari, A. 2000. Studi Tentang Sumberdaya Ikan Pelagis Kecil Utama yang Didaratkan di Propinsi Bengkulu. (Skripsi, tidak dipublikasikan). Program Studi Pemanfaatan Sumberdaya Perikanan, Fakultas Perikanan dan Ilmu Kelautan, Institut Pertanian Bogor, Bogor 84 hal.

Pauly, D. 1984. Fish Population Dynamics in Tropical Waters : a Manual for Use With Programmable Calculators. ICLARM. Manila. Filipina.325 p.

Handoyo, D. 1991. Analisis Tingkat Pengusahaan Sumberdaya Ikan Kembung (Rastrelliger spp) pada Tiap Musim Penangkapan Ikan di Perairan Utara Jawa. Skripsi. Program Studi Ilmu dan Teknologi Kelautan, Fakultas Perikanan. IPB. Bogor. 115 hal.

Widodo, J dan Suadi. 2006. Pengelolaan Sumberdaya Perikanan Laut. Gajah Mada University Press. Yogyakarta.252 hlm. 


\title{
EVALUASI KECERNAAN PAKAN IKAN NILA Orechomis niloticus PADA TIGA STADIA YANG BERBEDA
}

\author{
Firsty Rahmatia, S.pi., M.Si ${ }^{1}$ \\ ${ }^{1}$ Program Studi Budidaya Perairan, Fakultas Perikanan dan ilmu kelautan, \\ Universitas Satya Negara Indonesia
}

\begin{abstract}
Feed is one of the most important part in intensive aquaculture system. Economically, the costs incurred for feed needs is $65 \%$ of total production costs. Fish obtain the energy to do all the activities of life and growth of feed consumed. Feed eaten will not be fully utilized by the fish for the energy fulfillment. Before being absorbed by the body and used for energy and growth, feed eaten will be through multiple pathways. Feed remains will back to the body in the form of feces. Thus, the ability to feed absorption by the fish depends on the ability of digestibility by the fish itself. The better the fish digestive ability the less the rest of the feed banished (feces). This research held to determine the digestibility of tilapia in three different stadia ( small, medium, and large). Then be viewed profiles enzyme activity associated with the stadia and ability of feed utilization. Large tilapia sized 7-8 cm with an average weight $25.17 \mathrm{~g}$, medium tilapia $4-5 \mathrm{~cm}$ with an average weight of $13.58 \mathrm{~g}$ and small tilapia $2-3 \mathrm{~cm}$ with an average weight 0.74 g. Total Feed Consumption (JKP ), Relative Growth (PR), Feed Conversion Ratio (FCR), Retention Fat (RL), Retention Protein (RP), digestibility level, and protease enzymes. Total consumption of large fish feed more than medium and small fish, but the relative growth of large and medium fish smaller than small fish. However, protease enzyme activity and digestibility did not show significantly different.
\end{abstract}

Keywords : Tilapia, feed, digestibility, different stadia

\begin{abstract}
ABSTRAK
Pakan merupakan salah satu bagian terpenting dalam budidaya secara intensif. Ditinjau dari segi ekonomi, biaya yang dikeluarkan untuk kebutuhan pakan mencapai $65 \%$ dari total biaya produksi. Ikan memperoleh energi untuk melakukan segala aktivitas kehidupan dan pertumbuhan dari pakan yang dikonsumsinya. Pakan yang dimakan tidak akan seluruhnya dimanfaatkan oleh ikan untuk pemenuhan energi tersebut. Sebelum diserap oleh tubuh dan dimanfaatkan sebagai sumber energi dan pertumbuhan, pakan yang dimakan akan melalui beberapa jalur terlebih dahulu. Sisa pakan yang tidak dapat diserap akan dikeluarkan kembali dari tubuh dalam bentuk feses. Dengan demikian, kemampuan penyerapan pakan oleh ikan bergantung pada kemampuan cerna pakan oleh ikan itu sendiri. Semakin baik kemampuan cerna ikan maka akan semakin sedikit sisa makanan yang dibuangnya (feses). Penelitian ini perlu dilakukan untuk mengetahui kecernaan ikan nila pada tiga stadia yang berbeda (kecil, sedang, dan besar). Kemudian dapat dilihat profil aktivitas enzim terkait dengan stadia dan kemampuan pemanfaatan pakan. Ukuran ikan nila besar yang
\end{abstract}


digunakan adalah $7-8 \mathrm{~cm}$ dengan bobot rata - rata 25,17 g/ekor, nila sedang $4-5 \mathrm{~cm}$ dengan bobot rata-rata 13,58 g/ekor dan nila kecil $2-3 \mathrm{~cm}$ dengan bobot rata - rata 0,74 g/ekor. Parameter yang diamati adalah Jumlah Konsumsi Pakan (JKP), Pertumbuhan Relatif (PR), Feed Conversion Ratio (FCR), Retensi Lemak (RL), Retensi Protein (RP), Kecernaan, dan enzim protease. Jumlah konsumsi pakan ikan besar lebih banyak daripada jumlah konsumsi pakan ikan sedang dan kecil, namun sebaliknya, pertumbuhan relatif ikan besar dan sedang lebih kecil daripada ikan kecil. Namun, aktivitas enzim protease dan kecernaan tidak memiliki perbedaan yang berbeda nyata.

\section{Kata kunci : Ikan nila, pakan, kecernaan, stadia berbeda}

\section{PENDAHULUAN}

Budidaya ikan melibatkan beberapa input seperti wadah atau tempat pemeliharaan, benih, pakan, obat-obatan, dan teknologi budidaya. Pakan merupakan salah satu bagian terpenting dalam budidaya terutama budidaya secara intensif. Ditinjau dari segi ekonomi, biaya yang dikeluarkan untuk kebutuhan pakan mencapai $65 \%$ dari total biaya produksi.

Ditinjau dari kegunaannya, pakan menjadi penting karena mempengaruhi pertumbuhan ikan yang dibudidayakan. Ikan memperoleh energi untuk melakukan segala aktivitas kehidupan dan pertumbuhan dari pakan yang dikonsumsinya. Akan tetapi, pakan yang dimakan tidak akan seluruhnya dimanfaatkan oleh ikan untuk pemenuhan energi tersebut. Sebelum diserap oleh tubuh dan dimanfaatkan sebagai sumber energi dan pertumbuhan, pakan yang dimakan akan melalui beberapa jalur terlebih dahulu.

Ikan akan mengambil pakan dengan mulut dan memakannya, selanjutnya masuk ke dalam sistem pencernaan dan dicerna menjadi molekul-molekul sederhana yang mampu diserap oleh tubuh. Pakan diserap oleh dinding usus dan masuk ke dalam sistem peredaran darah (Tytler dan Clow, 1985 dalam Fitriliyani, 2011). Sisa pakan yang tidak dapat diserap akan dikeluarkan kembali dari tubuh dalam bentuk feses. Dengan demikian, kemampuan penyerapan pakan oleh ikan bergantung pada kemampuan cerna pakan oleh ikan itu sendiri. Semakin baik kemampuan cerna ikan maka akan semakin sedikit sisa makanan yang dibuangnya (feses).

Sistem pencernaan terbagi atas tiga jenis, yaitu pencernaan mekanik, pencernaan kimiawi, dan pencernaan biologis (Affandi et al., 2009). Kebanyakan spesies ikan budidaya tidak memiliki gigi sehingga pencernaan mekanik di rongga mulut tidak terjadi. Ikan juga tidak memiliki rumen seperti ruminansia sebagai tempat berkembangnya bakteri sebagai pencerna biologis. Sehingga salah satu faktor yang paling mempengaruhi kemampuan cernanya adalah aktivitas enzim sebagai pencernaan kimiawi (Hepher, 1990 dalam Fitriliyani, 2011).

Berdasarkan hal tersebut, penelitian ini perlu dilakukan untuk mengetahui kecernaan ikan nila pada tiga stadia yang berbeda (kecil, sedang, dan besar). Untuk kemudian dapat dilihat profil aktivitas enzim terkait dengan stadia dan kemampuan pemanfaatan pakan. Penelitian ini bertujuan untuk mengevaluasi 
kualitas dan kecernaan pada ikan nila Oreochromis niloticus untuk ukuran kecil, sedang, dan ukuran besar.

\section{BAHAN DAN METODE}

\section{Waktu dan Tempat}

Penelitian dilakukan selama 3 bulan, bertempat di Laboratorium Akuakultur, Fakultas Perikanan dan Ilmu Kelautan, Universitas Satya Negara Indonesia.

\section{Prosedur Penelitian}

\section{Ikan Uji}

Ikan uji yang digunakan dalam penelitian ini adalah ikan nila. Ukuran ikan nila besar yang digunakan adalah $7-8 \mathrm{~cm}$ dengan bobot rata - rata $25,17 \mathrm{~g} / \mathrm{ekor}$, nila sedang 4-5 cm dengan bobot rata-rata 13,58 g/ekor dan nila kecil $2-3 \mathrm{~cm}$ dengan bobot rata - rata 0,74 g/ekor. Ikan nila dipelihara di dalam wadah akuarium berukuran dengan kepadatan 10 ekor/akuarium (nila besar), 20 ekor/akuarium (nila sedang), dan 30 ekor/akuarium (nila kecil). Ikan uji tersebut kemudian diadaptasikan (aklimatisasi) terhadap pakan, media hidup dan wadah pemeliharaan selama 2 hari. Selanjutnya dipuasakan selama 24 jam untuk menghilangkan sisa pakan dalam saluran pencernaan ikan.

\section{Pakan Uji}

Pakan uji yang digunakan adalah pakan komersil. Sebelum diberikan, pakan uji telah dicampurkan dengan kromium trioksida $\left(\mathrm{Cr}_{2} \mathrm{O}_{3}\right)$ sebanyak 0,5\% terlebih dahulu (repelleting) sebagai indikator kecernaan (NRC, 1993).

Manajemen pemberian pakan adalah dilakukan dua kali sehari yaitu pada pukul 07.00 dan 16.00 secara at satiation (sekenyangnya). Sebelum pemberian pakan, akuarium disifon untuk menghilangkan sisa-sisa pakan dan kotoran. Pada hari ke-5 setelah ikan diberi pakan perlakuan, feses mulai dikumpulkan kemudian disimpan dalam botol film. Feses yang terkumpul tersebut disimpan dalam freezer untuk menjaga kesegarannya.

\section{Analisis Kimia}

Analisis proksimat dilakukan terhadap pakan perlakuan dan ikan uji. Analisis yang dilakukan pada pakan perlakuan meliputi kadar protein, lemak, serat kasar, kadar abu, dan kadar air. Sedangkan untuk ikan uji meliputi analisis protein, lemak, dan kadar air.

Analisis proksimat untuk protein dilakukan dengan metode Kjeldahl, lemak pakan dilakukan dengan metode Soxhlet, lemak ikan dilakukan dengan metode Folch, kadar abu dengan pemanasan dalam tanur bersuhu $600{ }^{\circ} \mathrm{C}$, serat kasar menggunakan metode pelarutan sampel dengan asam dan basa kuat serta pemanasan, dan kadar air dengan pemanasan dalam oven bersuhu $105-110{ }^{\circ} \mathrm{C}$ (Takeuchi, 1988).

\section{Analisis kecernaan}


Analisis kecernaan dilakukan setelah pengumpulan feses telah selesai dilakukan, yaitu pada akhir penelitian setelah pemeliharaan selama 30 hari. Pengukuran kinerja pertumbuhan juga dilakukan pada akhir pemeliharaan. Feses yang telah terkumpul kemudian dikeringkan menggunakan oven bersuhu $105-110{ }^{\circ} \mathrm{C}$ selama 5-6 jam. Selanjutnya dilakukan analisis kromium trioksida $\mathrm{Cr}_{2} \mathrm{O}_{3}$ pada feses yang sudah dikeringkan. Analisis $\mathrm{Cr}_{2} \mathrm{O}_{3}$ dalam pakan dan feses dilakukan dengan proses oksidasi dan dilanjutkan dengan pembacaan nilai absorban menggunakan spektrofotometer dengan panjang gelombang $350 \mathrm{~nm}$.

\section{Parameter Pengamatan}

\section{Jumlah Konsumsi Pakan (JKP)}

Jumlah pakan yang diberikan setiap hari dikurangi jumlah pakan yang tersisa. Pakan yang diberikan selama percobaan kemudian dijumlahkan.

\section{Kecernaan}

Parameter kecernaan yang dihitung berdasarkan Watanabe (1988) dan NRC (1993) adalah sebagai berikut :

$$
\begin{array}{ll}
\text { Kecernaan protein } & =100-\left[100 \times \text { a } / \mathrm{a}^{\prime} \mathrm{x} \mathrm{b} / \mathrm{b}^{\prime}\right] \\
\text { Energi tercerna } & =\text { Energi pakan }-\left(\text { Energi feses } \mathrm{x} \mathrm{n} / \mathrm{n}^{\prime}\right) \\
\text { Kecernaan energi } & =[\text { Energi tercerna/Energi pakan }] \times 100 \% \\
\text { Kecernaan bahan } & =(\text { ADT-0,7AD }) / 0,3
\end{array}
$$

Keterangan :

$$
\begin{array}{ll}
\mathrm{a} & =\% \mathrm{Cr} 2 \mathrm{O} 3 \text { dalam pakan } \\
\mathrm{a}, & =\% \mathrm{Cr} 2 \mathrm{O} 3 \text { dalam feses } \\
\mathrm{b} & =\% \text { protein dalam pakan } \\
\mathrm{b}, & =\% \text { protein dalam feses } \\
\mathrm{n} & =\mathrm{mg} \mathrm{Cr} 2 \mathrm{O} 3 / \mathrm{g} \text { pakan } \\
\mathrm{n}, & =\mathrm{mg} \mathrm{Cr} 2 \mathrm{O} 3 / \mathrm{g} \text { feses } \\
\mathrm{ADT} & =\text { nilai kecernaan pakan uji } \\
\mathrm{AD} & =\text { nilai kecernaan pakan acuan }
\end{array}
$$

\section{Tingkat Kelangsungan Hidup (Survival Rate)}

Tingkat kelangsungan hidup dihitung berdasarkan persamaan:

$$
\mathrm{SR}=[\mathrm{Nt} / \mathrm{No}] \times 100 \%
$$

Keterangan :

$$
\begin{array}{lll}
\mathrm{SR} & = & \text { Kelangsungan hidup ikan } \\
\mathrm{Nt} & = & \text { Jumlah ikan pada akhir pemeliharaan } \\
\mathrm{No} & = & \text { Jumlah ikan pada awal pemeliharaan }
\end{array}
$$

\section{Pertumbuhan Relatif}

Pertumbuhan relatif dihitung dengan menggunakan rumus :

$$
\mathrm{PR}=[(\mathrm{Wt}-\mathrm{Wo}) / \mathrm{Wo}] \times 100 \%
$$

Keterangan :

$$
\begin{array}{lll}
\mathrm{PR} & = & \text { Pertumbuhan relatif } \\
\mathrm{Wt} & = & \text { Biomassa ikan pada waktu } \mathrm{t}(\mathrm{gram}) \\
\mathrm{Wo} & = & \text { Biomassa ikan pada awal pemeliharaan }(\mathrm{gram})
\end{array}
$$

Konversi Pakan (Feed Conversion Ratio, FCR) 
Efisiensi pakan dihitung dengan menggunakan rumus :

$$
\mathrm{FCR}=\{((\mathrm{Wt}+\mathrm{D}) / \mathrm{F})-\mathrm{Wo}]\}
$$

Keterangan :

$\begin{array}{lll}\mathrm{FCR} & = & \text { Konversi pakan } \\ \mathrm{F} & = & \text { Jumlah pakan kering yang diberikan } \\ \mathrm{Wt} & = & \text { Biomassa ikan pada waktu } \mathrm{t} \text { (gram) } \\ \mathrm{Wo} & = & \text { Biomassa ikan pada awal pemeliharaan (gram) } \\ \mathrm{D} & = & \text { Bobot ikan yang mati selama penelitian (gram) }\end{array}$

\section{Retensi Nutrien (protein, lemak, karbohidrat)}

Nilai retensi protein dihitung berdasarkan persamaan (Takeuchi, 1988); $\mathrm{RP}=[(\mathrm{F}-\mathrm{I}) / \mathrm{P}] \times 100 \%$

Keterangan :

$\begin{array}{lll}\mathrm{RP} & = & \text { Retensi nutrien }(\%) \\ \mathrm{F} & = & \text { Jumlah nutrien tubuh ikan pada akhir pemeliharaan (gram) } \\ \mathrm{I} & = & \text { Jumlah nutrien tubuh ikan pada awal pemeliharaan (gram) } \\ \mathrm{P} & = & \text { Jumlah nutrien yang dikonsumsi ikan (gram) }\end{array}$

\section{Analisis Data}

Desain penelitian adalah menggunakan Rancangan Acak Lengkap (RAL) satu faktor yaitu stadia ikan. Analisis sidik ragam (ANOVA) dilakukan dengan menggunakan perangkat lunak SPSS 16.00, apabila terdapat pengaruh yang berbeda nyata $(\mathrm{P}<0.05)$ maka dilakukan uji lanjut Tukey.

\section{HASIL DAN PEMBAHASAN}

\section{Hasil}

Hasil analisis proksimat pakan perlakuan yang digunakan dalam penelitian disajikan pada tabel di bawah ini.

Tabel 2. Hasil Analisis Proksimat Pakan (\% bobot basah)

\begin{tabular}{cccccc}
\hline $\begin{array}{c}\text { Kadar } \\
\text { Air }\end{array}$ & $\begin{array}{c}\text { Kadar } \\
\text { Abu }\end{array}$ & $\begin{array}{c}\text { Kadar } \\
\text { Protein }\end{array}$ & $\begin{array}{c}\text { Kadar } \\
\text { Lemak }\end{array}$ & $\begin{array}{c}\text { Kadar Serat } \\
\text { kasar }\end{array}$ & $\begin{array}{c}\text { Kadar } \\
\text { BETN }\end{array}$ \\
\hline 7.73 & 15.29 & 29.14 & 3.83 & 3.31 & 40.7 \\
\hline
\end{tabular}

Setelah 30 hari masa pemeliharaan maka diamati parameter-parameter kinerja pertumbuhan. Hasil pengamatan tersaji dalam tabel di bawah ini.

Tabel 3. Kinerja Pertumbuhan Ikan Nila

\begin{tabular}{|l|c|c|c|c|c|c|c|}
\hline $\begin{array}{l}\text { Stadia } \\
\text { Ikan }\end{array}$ & JKP & PR (\%) & FCR & RL (\%) & RP (\%) & KP (\%) & $\begin{array}{c}\text { Enzim } \\
\text { Protease }\end{array}$ \\
\hline Kecil & $49.54 \pm 17.19^{\mathrm{a}}$ & $117.56 \pm 26.45^{\mathrm{b}}$ & $2.05 \pm 1.11^{\mathrm{a}}$ & $0.04 \pm 0.01^{\mathrm{a}}$ & $0.05 \pm 0.04^{\mathrm{a}}$ & $56.92 \pm 12.52^{\mathrm{a}}$ & $1.13 \pm 0.83^{\mathrm{a}}$ \\
\hline Sedang & $65.76 \pm 13.84^{\mathrm{a}}$ & $25.47 \pm 7.26^{\mathrm{a}}$ & $2.59 \pm 1.19^{\mathrm{a}}$ & $0.20 \pm 0.07^{\mathrm{a}}$ & $0.09 \pm 0.04^{\mathrm{a}}$ & $55.22 \pm 6.90^{\mathrm{a}}$ & $0.90 \pm 0.30^{\mathrm{a}}$ \\
\hline Besar & $105.38 \pm 9.43^{\mathrm{b}}$ & $18.30 \pm 6.13^{\mathrm{a}}$ & $3.07 \pm 0.95^{\mathrm{a}}$ & $0.49 \pm 0.11^{\mathrm{b}}$ & $0.06 \pm 0.05^{\mathrm{a}}$ & $57.41 \pm 2.67^{\mathrm{a}}$ & $1.10 \pm 0.87^{\mathrm{a}}$ \\
\hline
\end{tabular}

Keterangan : Huruf superskript yang berbeda pada kolom yang sama menunjukkan hasil yang berbeda nyata $(\mathrm{P}<0.05)$.

JKP : Jumlah Konsumsi Pakan

PR : Pertumbuhan Relatif

FCR : Feed Convertion Ratio 


\section{RL : Retensi Lemak \\ RP : Retensi Protein \\ KP : Kecernaan Pakan}

\section{Pembahasan}

Ikan nila termasuk dalam famili Cichlidae yang memiliki sifat mouthbreeder atau memelihara telur dan larva dalam mulut. Klasifikasi ikan nila menurut Trewavas (1982) adalah sebagai berikut :

$\begin{array}{ll}\text { Filum } & \text { : Chordata } \\ \text { Kub Filum } & \text { : Vertebrata } \\ \text { Sub kelas } & \text { : Osteichtyes } \\ \text { Ordo } & \text { : Perchanthoptherigi } \\ \text { Sub Ordo } & \text { : Percoidea } \\ \text { Famili } & \text { : Cichlidae } \\ \text { Genus } & \text { : Oreochromis } \\ \text { Spesies } & \text { : Oreochromis niloticus }\end{array}$

Ikan nila memiliki bentuk tubuh memanjang, ramping dan relatif pipih. Ikan nila juga memilki kemampuan adaptasi yang baik dalam berbagai jenis air, tahan terhadap perubahan lingkungan, bersifat omnivor, mampu mencerna makanan secara efisien, memiliki pertumbuhan yang cepat serta tahan terhadap penyakit. Ikan nila bersifat omnivora dan dapat memanfaatkan fitoplankton, zooplankton, bakteri dan detritus sebagai pakan. Ikan nila juga diketahui memiliki kemampuan untuk memfilter fitoplankton dengan diameter kurang dari $5 \mu \mathrm{m}$ di perairan (Lovell, 1989).

Permintaan pasar akan ikan nila terus meningkat. Hingga tahun 2005, kebutuhan ikan nila di Jawa Barat baru terpenuhi sekitar $21 \%$. Sedangkan berdasarkan data National Fisheries Service selama tahun 2006, Amerika telah mengimpor 60.772 ton ikan nila yang didatangkan dari berbagai negara, termasuk diantaranya adalah Indonesia. Total ekspor ikan nila Indonesia pada tahun 2005 sebesar 151.363 ton dan terus meningkat hingga mencapai 206.904 ton pada tahun 2007 (FAO, 2009).

Padat tebar ikan nila sangat bervariasi, bergantung pada sistem budidaya yang diterapkan. Padat tebar dan produktivitas ikan nila pada beberapa sistem budidaya dapat dilihat pada tabel 1 .

Tabel 1. Padat tebar dan produktivitas ikan nila pada beberapa sistem budidaya

\begin{tabular}{|l|c|c|}
\hline \multicolumn{1}{|c|}{ Sistem budidaya } & Padat tebar $\left(\mathrm{ikan} / \mathrm{m}^{3}\right)$ & Produktivitas $\left(\mathrm{kg} / \mathrm{m}^{3}\right)$ \\
\hline Ekstensif & $0,1-0,2$ & $0,03-0,07$ \\
\hline Semi intensif & $0,2-0,6$ & $0,4-0,8$ \\
\hline $\begin{array}{l}\text { Intensif (penambahan aerasi saat DO } \\
\text { rendah) }\end{array}$ & $1-3$ & $0,5-1$ \\
\hline Intensif (aerasi kontinu) & $1-3$ & $0,8-15$ \\
\hline Intensif (aerasi kontinu dan ganti air) & $5-10$ & $2-10$ \\
\hline Kolam air deras (raceways) & $70-200$ & $70-200$ \\
\hline Karamba (cages) & $50-100$ & $50-300$ \\
\hline
\end{tabular}

Sumber: Popma dan Lovshin (1996)

Makanan merupakan salah satu komponen dalam kegiatan budidaya yang baru akan bernilai guna bagi tubuh (sebagai sumber materi dan energi) setelah 
melalui proses pencernaan, dan penyerapan terlebih dahulu. Fisiologi pencernaan dan penyerapan menyangkut hal-hal berikut :

- Struktur alat pencernaan, berperan sebagai tempat berlangsungnya proses pencernaan dan penyerapan makanan.

- Biokimia dari bahan-bahan yang terkait dengan proses pencernaan, antara lain : zat makanan, enzim, mukus, asam khlorida, cairan empedu, garam bikarbonat, dan hormon.

- Mekanisme pencernaan dan penyerapan zat makanan, yakni mekanisme fisik dan kimia serta interaksi antara komponen-komponen yang terkait dengan pencernaan dan penyerapan sehingga makanan dapat dicerna, diserap, dan selanjutnya dimanfa'atkan oleh tubuh ikan.

Struktur saluran pencernaan ikan terdiri atas; mulut, rongga mulut, faring, esofagus, lambung, pilorus, usus, rektum, kloaka, dan anus. Sementara struktur kelenjar pencernaan meliputi hati, kantung empedu, dan pankreas. Pada proses pencernaan terjadi proses penyederhanaan makanan melalui bahan yang sederhana dan melarut yang dengan mudah dapat diserap dan diedarkan ke seluruh tubuh melalui sistem peredaran darah. Pencernaan terjadi secara fisik (mekanik), kimiawi, dan biologi. Kombinasi inilah yang menyebabkan perubahan makanan dari yang asalnya bersifat kompleks menjadi senyawa sederhana (Affandi et al., 2009).

Pada penelitian ini, parameter pertama yang diamati adalah jumlah konsumsi pakan. Parameter ini menunjukkan jumlah pakan yang dimakan oleh ikan uji. Jumlah konsumsi pakan menunjukkan palatabilitas pakan. Jumlah pakan yang dikonsumsi menunjukkan perbedaan yang berbeda nyata $(\mathrm{P}<0.05)$. JKP oleh ikan nila besar secara keseluruhan dua kali lipat lebih banyak dari pada pakan yang dikonsumsi oleh ikan sedang dan kecil. Hal ini dikarenakan ukuran yang lebih besar membuat kebutuhan energi semakin meningkat, sehingga kebutuhan akan pakan juga meningkat, didukung oleh kapasitas organ pencernaan untuk pakan akan lebih besar dan daya tampung lebih tinggi.

Pakan yang dikonsumsi ikan nila selama 30 hari dimanfaatkan ikan sebagai sumber energi untuk metabolisme basal dan pertumbuhan, secara kuantitatif dapat dilihat dari nilai parameter kedua yaitu pertumbuhan relatif (PR). Berdasarkan hasil pertumbuhan relatif menunjukkan hasil yang berbeda nyata $(\mathrm{P}<0.05)$, ikan nila kecil menunjukkan angka yang jauh lebih tinggi dari ikan nila sedang dan besar. Hal ini disebabkan oleh laju pertumbuhan pada stadia ini (juvenil) berada pada fase kecepatan maksimum yang kemudian akan melambat pada stadia ikan besar (dewasa). Ketika dewasa energi yang diperoleh tidak hanya digunakan untuk pertumbuhan somatik akan tetapi sebagian digunakan untuk pertumbuhan gonad atau reproduktif (Effendi, 2004).

Selanjutnya perbandingan jumlah pakan yang dikonsumsi dengan kinerja pertumbuhan ikan uji menggambarkan nilai konversi pakan (FCR). Berdasarkan Tabel 3, nilai FCR semua perlakuan tidak baik (FCR $>2$ ). Tingginya nilai konversi pakan dapat disebabkan oleh faktor nilai nutrisi (Guillaume, 2001) dan stabilitas pakan (Watanabe et al., 1983).

Nilai retensi protein dan retensi lemak menggambarkan adanya pemanfaatan nutrien pakan yang telah dicerna oleh tubuh ikan, diserap, dan disimpan untuk menghasilkan energi (Lovell, 1989). Kandungan protein pakan yang optimal pada 
ikan dipengaruhi oleh beberapa faktor seperti keseimbangan antara protein dan energi, komposisi asam amino, dan kecernaan protein (Halver, 1989).

Berdasarkan Tabel 3, semua perlakuan menunjukkan nilai retensi protein yang sangat rendah $(<1 \%)$. Menurut Abdel-tawwab et al. (2008), perubahan kandungan protein dan lemak dalam tubuh ikan dapat dikaitkan dengan perubahan sintesis dalam tubuh, tingkat penyerapan otot dan atau perbedaan tingkat pertumbuhan. Namun pada penelitian ini, nilai retensi protein baik pada ikan kecil maupun besar menunjukkan nilai yang hampir sama. Parameter kinerja pertumbuhan terakhir yang diamati adalah retensi lemak ikan. Seperti halnya retensi protein, semua perlakuan menunjukkan nilai retensi lemak yang rendah $(<1 \%)$.

Kecernaan kimiawi pakan terkait dengan aktivitas enzimatis yang terdapat pada saluran pencernaan. Enzim adalah katalisator biologis dalam reaksi kimia yang sangat dibutuhkan dalam kehidupan. Enzim adalah protein, yang disintesis dalam sel dan dikeluarkan dari sel yang membentuknya melalui proses eksositosis. Enzim yang disekresikan ke luar sel digunakan untuk pencernaan di luar sel (di dalam rongga pencernaan) atau disebut "extra cellular digestion", sedangkan enzim yang dipertahankan dalam sel digunakan untuk pencernaan dalam sel itu sendiri atau disebut "intra celuller digestion" (Affandi et al,. 2004). Enzim pencernaan yang disekresikan dalam rongga pencernaan berasal dari selsel mukosa lambung, pilorik kaeka, pankreas dan mukosa usus (Halver dan Hardy, 2002 dalam Fitriliyani, 2011 ).

Pada penelitian ini, nutrien yang menjadi fokus utama adalah protein, karena protein berfungsi sebagai sumber energi untuk tumbuh. Enzim yang terkait dengan kecernaaan protein adalah enzim protease. Keberadaan enzim tergantung pada stadia dan kelengkapan organ pencernaan yang dimiliki oleh ikan. Ikan besar memiliki organ yang lebih sempurna dibandingkan dengan ikan kecil sehingga aktivitas enzimnya akan lebih tinggi. NAS (1983) menyatakan bahwa tingkat kecernaan terhadap suatu jenis pakan bergantung kepada kualitas pakan, komposisi bahan pakan, kandungan gizi pakan, jenis serta aktivitas enzim-enzim pencernaan pada sistem pecernaan ikan, ukuran dan umur ikan serta sifat fisik dan kimia perairan.

Nilai kecernaan yang tinggi terkait dengan serat kasar yang terkandung di dalam pakan, semakin rendah kadar serat kasar maka ikan akan lebih mudah mencerna dan menyerap nutrien termasuk protein. Bedasarkan uji statistik (Tabel 3 ), enzim protease yang terkandung pada ikan kecil, ikan sedang dan ikan besar menunjukkan nilai yang tidak berbeda nyata $(\mathrm{P}>0.05)$. Dengan demikian, dapat disimpulkan bahwa ikan nila mulai ukuran $2-3 \mathrm{~cm}$ diduga telah memiliki sistem organ dan kelenjar pencernaan yang sempurna, sehingga kemampuan cernanya dapat menyamai nila ukuran yang lebih besar.

\section{KESIMPULAN}

\section{Kesimpulan}

Jumlah konsumsi pakan ikan besar lebih banyak daripada jumlah konsumsi pakan ikan sedang dan kecil, namun sebaliknya, pertumbuhan relatif ikan besar dan sedang lebih kecil daripada ikan kecil. Ikan nila mulai ukuran 2-3 cm diduga 
telah memiliki sistem organ dan kelenjar pencernaan yang sempurna, sehingga kemampuan cernanya dapat menyamai nila ukuran yang lebih besar.

\section{DAFTAR PUSTAKA}

Abdel-tawwab, M, Ahmad, MH, Abdel-Hadi, YM, Seden, MEA. 2008. Use of spirulina Spirulina platensis as a growth and immunity promoter for nile tilapia, Oreochromis niloticus (1.) fry challenged with pathogenic Aeromonas hydrophila. 8th International Symposium on Tilapia in Aquaculture 2008.

Affandi, R, Sjafei, DS, Rahardjo, MF, Sulistiono, 2009. Fisiologi ikan: Pencernaan dan penyerapan makanan. Fakultas Perikanan dan Ilmu Kelautan - Institut Pertanian Bogor.

Effendi, I. 2004. Pengantar Akuakultur. Penebar Swadaya, Jakarta

Fitriliyani, I. 2011. Aktifitas enzim saluran pencernaan ikan nila (Oreohromis niloticus) dengan pakan mengandung tepung daun lamtoro (Leucaena leucophala) terhidrolisis dan tanpa hidrolisis dengan ekstrak enzim cairan rumen domba. Bioscientiae: Volume 8, Nomor 2, Juli 2011, Halaman 16-31.

[FAO] Food and Agricultural Organization. 2009. Tilapia market report - January 2008. http: //www.fao.org [April 25 2009 ].

Guillaume, J. 2001. Nutrition and Feeding of Fish and Crustaceans. University of Aberdeen, United Kingdom.

Halver, JE. 1989. Fish Nutrition, second ed. Academy Press Inc, New York.

Lovell, T. 1989. Nutrition and Feeding of Fish. Van Nostrand Reinhold, New York.

[NAS] National Academy of Science. 1983. Nutrient requirement of warmwater fish and shellfish. Revised Edition. National Academic Press, Washington DC, pp. 1-50.

[NRC] Nutritional Research Council. 1993. Nutrient Requirement of Fish. National Academic Press, Washington DC, pp. 43-44.

Popma TJ, Lovshin LL. 1996. World prospect for commercial production of tilapia. Research and Development Series No. 41. International Center for Aquaculture and Aquatic Environmens. Departement of Fisheries and Allied Aquacultures Auburn University. Alabama. 23 p.

Takeuchi, T. 1988. Laboratory Work Chemical Evaluation of Dietary Nutriens. In: Fish Fish Nutrition and Mariculture. Watanabe, T. Department of Aquatic Biosience. Tokyo University of Fisheries. JICA p. 179-226.

Trewavas, E. 1982. Tilapia : taxonomy and speciation in : Pullin, R.S.V., LoweMcConnel, R.H., The biology and culture of tilapias. ICLARM. Manila. The philippines. p: 3-14.

Watanabe, T, Cho, CY, Cowey, CB. 1983. Finfish Nutrition in Asia. Approaches to Research and Development, Tokyo University of Fisheries. 


\title{
ANALISIS TINGKAT PEMANFAATAN DAN MUSIM PENANGKAPAN IKAN PELAGIS DI PERAIRAN PRIGI JAWA TIMUR \\ Hari Ilhamdi ${ }^{1}$, Riena Telussa ${ }^{2}$, Dwi Ernaningsih ${ }^{3}$ \\ ${ }^{1,2,3}$ Fakultas Perikanan dan Ilmu Kelautan
}

\begin{abstract}
Abstrack
Pelagic fish resources is an important role in the Indonesian fishing industry. The increasing demand for fishery products, led to the exploitation of this resource continues both by traditional and semi-industrial fisheries. This is could threaten the sustainability of the resource. The research aims to; (1) Calculating MSY of pelagic fish; (2) analyze the utilization rate of pelagic fish; (3) determine fishing season pelagic fish in the Prigi water.

The study was conducted in Nusantara Fishing Port Prigi - Trenggalek, East Java in June-July 2014, data used are the catch from 2006 to 2013, the data analysis using surplus production models using the Schaefer method. Analysis fishing season using the Moving Average Method. The highest index is the fishing season and the lowest index is a bad season

There are 4 species of pelagic fish in Prigi water frigate mackerel (Auxis thazard), mackerel scad (Decapterus macrosoma), Balinese sardine (Sardinela lemuru), and skipjack (Katsuwonus pelamis). frigate mackerel production in 2013 is 7,291 tons, with MSY 7783 tons. The utilization rate frigate mackerel at Prigi water 94\%. Status of utilization of frigate mackerel has fully exploited. mackerel scad production in 2013 is 5,050 tons with 4,106 tons of MSY, and the utilization rate has exceeded, the MSY is equal to $123 \%$. Status of utilization over exploited. Balinese sardine production by 2013 is 3,051 tons, with 3,304 tons of MSY, and the utilization rate of $93 \%$. Status of utilization of Balinese sardine in the stage fully exploited. Skipjack production by 2013 as much as 616 tons to 949 tons of MSY. The average utilization rate of $83 \%$ and the status is fully exploited. There are four other pelagic fish species are also caught in the Prigi waters that common dolphin fish (Coryphanea hippurus), slimy mackerel (Scomber australasius), hardtail scad (Chorinrmus toll) and trevally (Selaroides chrumenupthalmus). These fish are by catch because catch relatively small on average below $2 \%$ of the total pelagic fish production in Prigi.

Based on the index of fishing season is known fishing season Balinese sardine and mackerel scad occurred two times a year i.e. in the second transitional season from east to west monsoon season (July-September) and the beginning of the west monsoon season (October). While bad season from December to April. fishing season of frigate mackerel from April to October. December to March is the bad season for fishing season. Fishing season skipjack from June to December with a peak season in September to October, while the bad season of skipjack from January to May.
\end{abstract}

\section{Abstrak}

Sumberdaya ikan pelagis memegang peranan penting dalam industri perikanan Indonesia. Meningkatnya permintaan produk perikanan, menyebabkan eksploitasi terhadap sumberdaya ini terus dilakukan baik oleh perikanan tradisional maupun semi industri. Penangkapan yang terus menerus dilakukan dapat mengancam kelestarian sumberdaya. Penelitian bertujuan untuk ; (1) Menghitung nilai MSY ikan pelagis di Perairan Prigi; (2) Menganalisis tingkat pemanfaatan ikan pelagis di Perairan Prigi; (3) Mengetahui musim ikan pelagis di Perairan Prigi. 
Penelitian dilakukan di Pelabuhan Perikanan Nusantara Prigi Trenggalek Jawa Timur bulan Juni - Juli 2014. Data yang digunakan adalah data hasil tangkapan dari tahun dari 2006 hingga 2013. Analisa data menggunakan model surplus produksi dengan menggunakan metode Schaefer. Analisa musim penangkapan menggunakan metode rata rata bergerak. Indeks tertinggi merupakan musim ikan dan indeks terendah merupakan musim paceklik

Terdapat 4 jenis ikan pelagis yaitu tongkol krai (Auxis thazard), layang (Decapterus macrosoma), lemuru (Sardinela lemuru), dan cakalang (Katsuwonus pelamis). Produksi ikan tongkol krai pada tahun 2013 sebanyak 7.291 ton, dengan MSY sebesar 7.783 ton. Tingkat pemanfaatan ikan tongkol krai di Prigi sebesar 94\%. Status pemanfaatan ikan tongkol krai telah masuk tahap fully exploited. Produksi ikan layang pada tahun 2013 sebanyak 5.050 ton dengan MSY sebesar 4.106 ton, dan tingkat pemanfaatan telah melebihi MSY yaitu sebesar 123\%. Status pemanfaatan over exploited. Produksi ikan lemuru hingga 2013 sebanyak 3.051 ton, dengan MSY sebesar 3.304 ton, dan tingkat pemanfaatan 93\%. Status pemanfaatan ikan lemuru telah masuk tahap fully exploited. Produksi ikan cakalang hingga 2013 sebanyak 616 ton dengan MSY sebesar 949 ton. Tingkat pemanfaatan rata-rata sebesar 83\% dan status penangkapan juga telah masuk fully exploited. Terdapat empat jenis ikan pelagis lainnya yang juga tertangkap di Perairan Prigi setiap tahunnya yaitu lemadang (Coryphanea hippurus), slengseng (Scomber australasius), tetengkek (Chorinrmus tol) dan bentong (Selaroides chrumenupthalmus). Ikan tersebut merupakan hasil tangkapan sampingan (by catch) dan jumlahnya relatif kecil yakni rata rata di bawah $2 \%$ dari total produksi ikan pelagis di Prigi.

Berdasarkan nilai indeks musim penangkapan diketahui Musim ikan lemuru dan layang terjadi 2 kali dalam setahun yaitu pada musim peralihan II dari musim timur ke musim barat (Juli- September) dan awal musim barat (Oktober). Musim paceklik berlangsung dari bulan Desember hingga April. Musim ikan tongkol krai di Prigi berlangsung dari bulan April hingga Oktober. Bulan Desember hingga Maret merupakan musim paceklik ikan Tongkol krai. Musim ikan cakalang berlangsung semenjak bulan Juni hingga Desember dengan musim puncak di bulan September hingga Oktober, sedangkan musim paceklik ikan cakalang berlangsung dari bulan Januari hingga bulan Mei.

Kata kunci : ikan pelagis, tingkat pemanfaatan, prigi.

\section{PENDAHULUAN}

Permintaan akan ikan pelagis terus meningkat baik dari dalam negeri maupun pasar ekspor. Permintaan pasar dalam negeri sendiri adalah untuk kebutuhan konsumsi sehari-hari karena nilai gizi dan proteinnya yang tinggi. Untuk pasar ekspor, selain untuk konsumsi beberapa jenis spesies pelagis kecil juga digunakan sebagai ikan umpan pada perikanan tuna long line. Oleh karena permintaannya yang selalu meningkat, eksploitasi terhadap sumberdaya ini terus dilakukan, baik oleh perikanan tradisional maupun semi industri. Penangkapan yang terus menerus dilakukan dapat mengancam kelestarian sumberdaya ini. Salah satu lokasi pendaratan ikan pelagis kecil di Selatan Jawa yang terbesar terdapat di Prigi Jawa Timur. Pengkajian terhadap status stok, tingkat pemanfaatan dan musim ikan pelagis kecil oleh nelayan pukat cincin yang berbasis di PPN Prigi ini perlu dilakukan sebagai langkah awal dalam pengelolaan perikanan yang lestari dan berkelanjutan. 


\section{TUJUAN}

Penelitian ini bertujuan untuk :

1. Menghitung nilai $M S Y$ (batas tangkapan lestari) ikan pelagis di Perairan Prigi.

2. Menganalisis sejauh mana tingkat pemanfaatan ikan pelagis kecil di Perairan Prigi.

3. Mengetahui musim ikan pelagis di Perairan Prigi.

\section{METODOLOGI}

Metode penelitian yang akan digunakan adalah dengan survey langsung ke lokasi dan melakukan pengamatan terhadap ikan hasil tangkapan dari kapal pukat cincin yang didaratkan di PPN Prigi. Data yang digunakan adalah data time series yang di dapatkan dari catatan pendaratan harian kapal kapal yang mendaratkan hasil tangkapannnya di Tempat Pelelangan Ikan di PPN Prigi selama 8 tahun yaitu dari tahun 2006 hingga 2013.

\section{Hasil Tangkapan per Upaya Penangkapan (Catch per Unit Effort)}

Data hasil tangkapan dan upaya penangkapan yang diperoleh dibuat dalam bentuk tabel, lalu menghitung nilai hasil tangkapan per upaya penangkapannya (Catch per Unit Effort atau CPUE). Rumus yang digunakan untuk mengetahui nilai CPUE adalah sebagai berikut (Gulland, 1982) :

$$
\text { CPUE }_{i}=\frac{\text { catch }_{i}}{\text { effort }} \quad i=1,2, \ldots, n
$$

dimana :

$$
\begin{aligned}
\text { CPUE }_{\mathrm{i}} & =\text { hasil tangkapan per upaya penangkapan dalam tahun } \mathrm{i} \\
\text { catch }_{\mathrm{i}} & =\text { hasil tangkapan dalam tahun } \mathrm{i} \\
\text { effort }_{\mathrm{i}} & =\text { upaya penangkapan dalam tahun } \mathrm{i}
\end{aligned}
$$

\section{Standardisasi Upaya Penangkapan}

Karena ikan yang tertangkap berasal dari beberapa alat tangkap yang berbeda dan kemampuan tangkap tiap alat tangkap juga berbeda-beda, maka perlu dilakukan standardisasi upaya penangkapan. Rumus yang dipakai untuk menstandardisasi upaya penangkapan adalah sebagai berikut (Gulland, 1982) :

(1) Menghitung Fishing Power Index (FPI)

$$
\mathrm{FPI}=\frac{\mathrm{CPUE}_{\mathrm{dst}}}{\mathrm{CPUE}_{\text {st }}}
$$

Keterangan :

$$
\begin{array}{ll}
\text { FPI } & =\text { Fishing Power Index } \\
\text { CPUE }_{\mathrm{dst}} & =\text { CPUE alat tangkap yang akan distandardisasi } \\
\text { CPUE }_{\mathrm{st}} & =\text { CPUE alat tangkap standar }
\end{array}
$$

(2) Standarisasi Alat tangkap

Menghitung Upaya Standar $f_{s}=F P I \times f_{d s t}$ 
Keterangan :

$$
\begin{aligned}
& \mathrm{f}_{\mathrm{s}}=\text { upaya penangkapan hasil standardisasi } \\
& \mathrm{f}_{\mathrm{dst}}=\text { upaya penangkapan yang akan distandardisasi }
\end{aligned}
$$

Nilai CPUE dihitung kembali dengan nilai upaya penangkapan yang baru, yaitu nilai upaya penangkapan setelah dilakukan standardisasi upaya penangkapan. Adapun nilai hasil tangkapan tetap sama.

Untuk mendapatkan gambaran pengaruh dari upaya penangkapan (f) terhadap hasil tangkapan per unit upaya penangkapan (CPUE) digunakan analisis regresi. Persamaan regresi linear sederhana dimaksudkan untuk mengetahui besarnya pengaruh antar peubah, dan bisa juga untuk mengetahui (meramal) nilai satu atau lebih peubah (Harahap, 1987 dalam Batubara, 1999).

Analisis terhadap hubungan antara upaya penangkapan (effort) dengan CPUE ikan diperoleh dengan menggunakan analisis regresi linier dengan persamaan :

$$
\hat{\mathrm{Y}}=\mathrm{a}+\mathrm{bx}
$$

Nilai a dan b diperoleh dari :

$$
b=\frac{n \sum x y-\sum x \sum y}{n \sum x^{2}-\left(\sum x\right)^{2}} \quad a=\frac{\sum y-b \sum x}{n}
$$

dimana $: \mathrm{Y}=$ peubah tak bebas $(\mathrm{CPUE})$ dalam ton/trip/unit.

$\mathrm{X}=$ peubah bebas (effort) dalam trip/unit.

\section{Potensi lestari (Maximum Sustainable Yield (MSY)}

Maksimum suistainable yield menggunakan metode schaefer yakni:

$$
\text { MSY }=-\mathrm{a}^{2} / 4 \mathrm{~b}
$$

Analisa data menggunakan program Microsoft Excel 2007.

\section{Analisis Tingkat Pemanfaatan}

Tingkat pemanfaatan suatu sumberdaya ikan dapat diketahui setelah didapatkan nilai MSY. Tingkat pemanfaatan dihitung dengan cara mempersentasekan jumlah hasil tangkapan pada tahun tertentu terhadap nilai MSY.

$$
\begin{aligned}
& T P i=\frac{\mathrm{c}}{\mathrm{MSY}} \times 100 \% \\
& \text { Keterangan }: \\
& \mathrm{TPi}=\text { tingkat pemanfaatan tahun } \mathrm{i} \\
& \mathrm{c} \quad=\text { hasil tangkapan (ton) } \\
& \mathrm{MSY}=\quad \text { maximum sustainable yield (ton) }
\end{aligned}
$$

Analisa data menggunakan program Microsoft Excel 2007. 


\section{Analisis Musim Penangkapan}

Musim ikan dapat diketahui dengan mencari indeks musim penangkapan (IMP) yang diperoleh melalui metode rata rata bergerak (random average) dengan mencari rata-rata data bulanan produksi dan laju tangkap selama beberapa tahun, yang selanjutnya di buat grafik. Titik tertinggi diasumsikan sebagai puncak musim ikan dan titik terendah merupakan bukan musim ikan (musim paceklik). Bila titik-titik musim tidak jelas maka dapat ditentukan melalui indeks musim, yaitu dengan menghitung kembali rata-rata dari jumlah total dan rata-rata bulanannya, dengan demikian akan terlihat dengan jelas bahwa titik tertinggi merupakan puncak musim, sedangkan titik terendah merupakan musim paceklik. Indeks musim penangkapan dapat diketahui dengan menggunakan metode sebagai berikut:

1. Menghitung rata-rata bulanan

$$
\overline{x l} \quad \underline{\sum x i j}
$$

2. Menghitung rata-rata umum

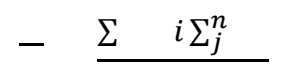

3. Indeks musim

Dimana :

$$
\begin{array}{ll}
\overline{x l} & =\text { Rata-rata produksi bulanan untuk tahun tertentu } \\
- & =\text { Rata rata produksi bulanan untuk keseluruhan tahun } \\
\mathrm{IM} & =\text { Indeks musim penangkapan ikan } \\
\mathrm{N} & =\text { jumlah tahun } \\
\mathrm{Xij} & =\text { Hasil tangkapan pada bulan ke-j tahun ke-i }
\end{array}
$$

\section{HASIL DAN PEMBAHASAN}

\section{Ikan Tongkol Krai}

Ikan tongkol krai merupakan spesies terbanyak yang ada di Perairan Prigi rata rata produksi ikan ini periode tahun 2006 - 2013 adalah 4.853 ton setiap tahunnya. Ikan tongkol krai tertangkap menggunakan alat tangkap purse seine, gillnet dan payang, dengan laju tangkap tertinggi pada alat tangkap purse seine, maka alat tangkap standar untuk ikan tongkol krai adalah purse seine. Nilai CPUE rata - rata ikan tongkol krai sebesar 35,23 ton/unit. Adapun nilai CPUE ikan tongkol krai di Prigi sepanjang tahun 2006 hingga 2013 dapat dilihat pada Gambar 1. 


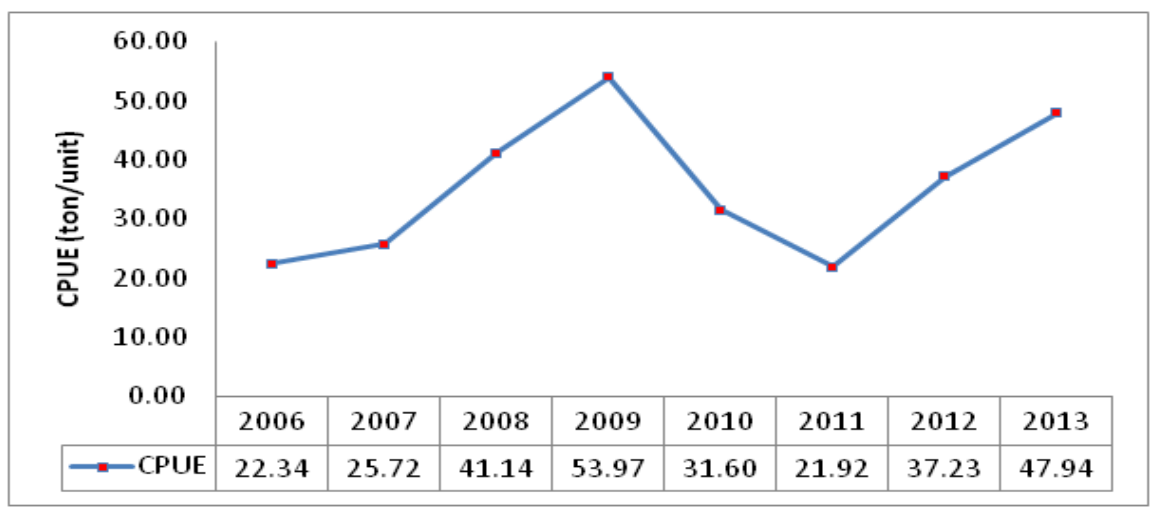

Gambar 1. Fluktuasi Laju Tangkap (CPUE) Ikan Tongkol Krai di Perairan Prigi Tahun 2006 2013.

Berdasarkan Gambar 1 terlihat bahwa nilai CPUE ikan tongkol krai dari tahun 2006 hingga 2009 mengalami kenaikan rata- rata 10,6 ton per tahun atau sebesar 33,3\%. Tahun 2009 hingga 2011 CPUE kembali menurun hingga 22 ton /unit atau berkurang sebesar $40 \%$ hal ini disebabkan karena penambahan upaya penangkapan sebanyak 37 unit (30\%) yang ternyata tidak berpengaruh terhadap penambahan jumlah produksi. Tahun 2012 dan 2013 nilai CPUE kembali naik rata - rata sebesar $27 \%$. CPUE rata rata yaitu 35,2 ton /unit berada jauh di atas CPUE optimum yakni 21,86 ton/unit.

MSY ikan tongkol krai di Prigi sebesar 7.783 ton dengan f optimum sebanyak 365 unit. Grafik MSY ikan tongkol krai di Prigi selengkapnya dapat dilihat pada Gambar 2.

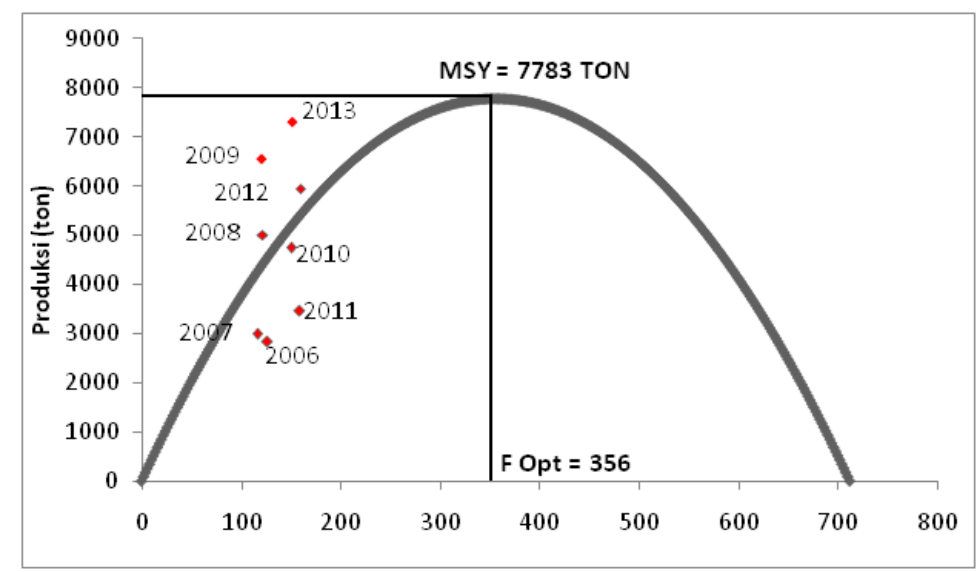

Gambar 2. Grafik MSY Ikan Tongkol Krai di Prigi.

Berdasarkan Gambar 2 terlihat hasil tangkapan tahun 2006 hingga 2013 berada di bawah batas MSY. Tahun 2008, 2009, 2012 dan 2013 meskipun jumlah hasil tangkapan masih di bawah MSY akan tetapi berada di luar kurva MSY, hal ini disebabkan karena CPUE pada tahun tersebut telah melebihi nilai CPUE optimum (21,86 ton/unit). Rata rata tingkat pemanfaatan ikan Tongkol krai di Prigi dari 2006 hingga 2013 sebesar 62\% akan tetapi hingga 2013 tingkat pemanfaatan sudah mencapai 94\%, melebihi jumlah tangkapan yang diperbolehkan. Hal ini senada dengan 
pernyataan Komnas Kajiskan (2006) dalam statistik perikanan 2007 dan Lelono (2011) yang mengatakan bahwa pemanfaatan ikan tongkol krai di Prigi telah berada pada status fully exploited. Tingkat pengupayaaan rata rata sebesar 39\% dari f optimum (365 unit) akan tetapi, penambahan upaya dalam hal ini armada penangkapan sudah tidak dianjurkan, karena CPUE rata rata saat ini telah melebihi CPUE Optimum. Penambahan upaya penangkapan tidak akan menambah jumlah hasil tangkapan.

\section{Ikan Layang}

Ikan Layang merupakan spesies terbanyak kedua yang ada di Prigi, tercatat dari tahun 2006 hingga 2013 produksi ikan layang di Prigi rata rata sebanyak 3.488,61 ton per tahun, dengan jumlah produksi terbanyak pada tahun 2013 yakni sebanyak 5.050 ton dan jumlah terkecil pada tahun 2006 yaitu sebanyak 2,633 ton. Ikan Layang di Prigi tertangkap pada alat tangkap purse seine dan payang, yang mana CPUE tertinggi dari alat tangkap purse seine. Berdasarkan hasil standarisasi diketahui bahwa purse seine merupakan alat tangkap standar. Setelah dilakukan standarisasi diperoleh CPUE Standar ikan layang di Prigi dari tahun 2006 hingga 2013 rata rata sebesar 25,7 ton/unit. Adapun nilai CPUE ikan layang di Prigi sepanjang 2006 hingga 2013 selengkapnya dapat dilihat pada Gambar 3.

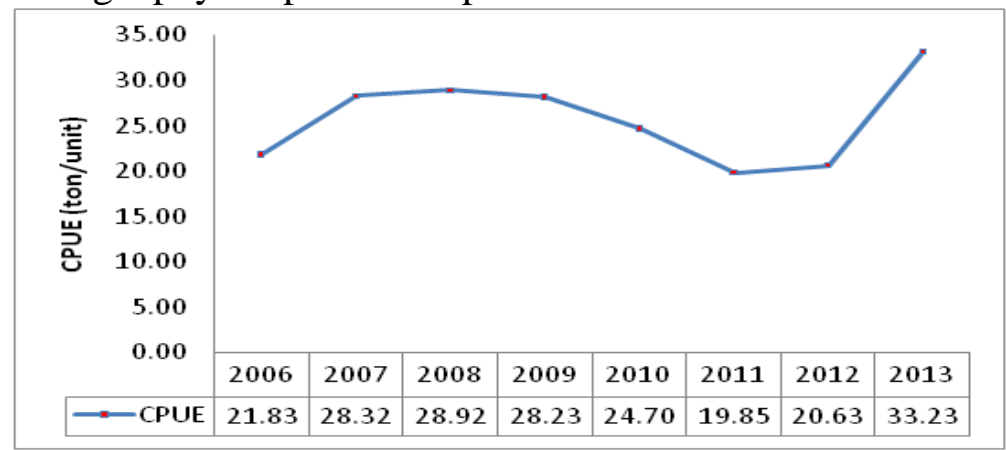

Gambar 3. Fluktuasi Laju Tangkap (CPUE) Ikan Layang di Perairan Prigi Tahun 2006 - 2013.

Berdasarkan Gambar 3 terlihat CPUE ikan layang pada tahun 2006 sebesar 21,8 ton/unit dan di tahun 2007 mengalami kenaikan sebesar 33\%. Tahun 2007 hingga 2009 nilai CPUE ikan layang relatif stabil yakni sebesar 28 ton/unit, Tahun 2009 hingga 2011 terjadi penurunan nilai CPUE sebesar 30\%, hal ini disebabkan karena adanya penambahan upaya penangkapan sebesar $30 \%$ yang tidak diikuti dengan penambahan jumlah produksi. Tahun 2012 hingga 2013 CPUE kembali bertambah sebesar 53\%. Rata- rata CPUE ikan layang di Prigi tahun 2006 hingga 2013 adalah 25,71 ton/unit, melebihi angka CPUE optimal yaitu sebesar 18,64 ton/unit.

Hasil analisis regresi linier yang membandingkan antara laju tangkap (CPUE) ikan layang dengan effort (unit), diperoleh angka MSY ikan layang sebesar 4,106 ton dan f optimum sebanyak 220 unit. Grafik MSY ikan layang di Prigi tahun 2006 hingga 2013 selengkapnya dapat dilihat pada Gambar 4. 


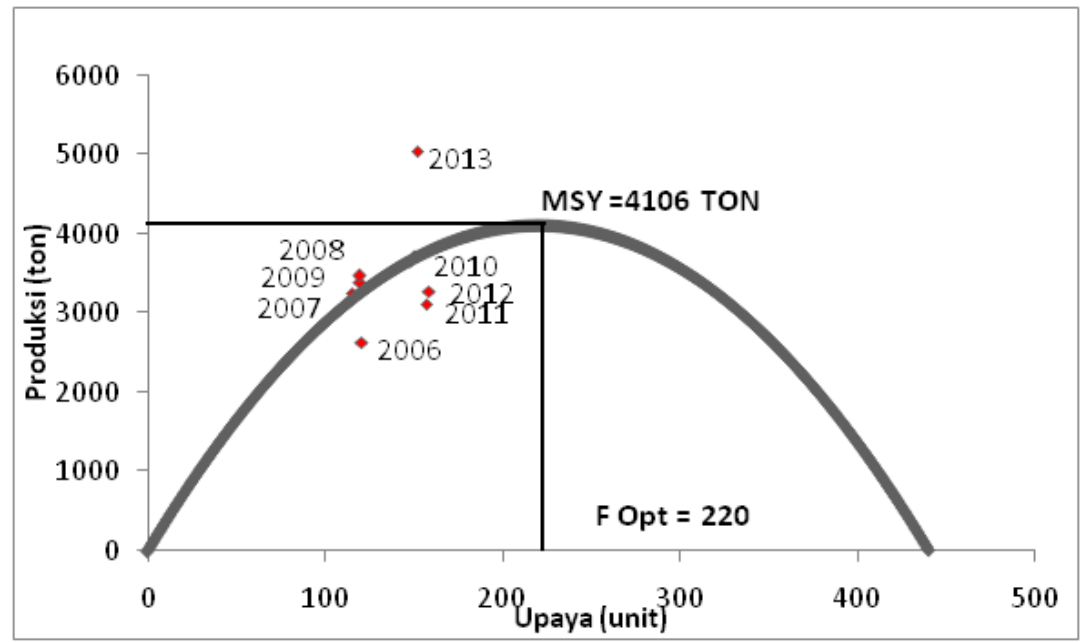

Gambar 4. Grafik MSY Ikan layang di Prigi tahun 2006 - 2013.

Berdasarkan gambar 4 terlihat pada tahun 2006, 2010, 2011 dan 2012 angka pemanfaatan berada di dalam kurva MSY yang berarti jumlah tangkapan berada di bawah batas MSY, dan upaya penangkapan yang dilakukan masih di bawah f optimum. Tahun 2007, 2008 dan 2009 jumlah tangkapan juga masih di bawah angka MSY akan tetapi berada di luar kurva MSY, nilai CPUE yang melebihi CPUE optimum pada tahun ini mengakibatkan jumlah tangkapan tahun 2010 hingga 2012 menurun, sementara terjadi penambahan jumlah upaya sebanyak 39 unit (32\%). Tahun 2013 produksi naik tinggi hingga melebihi jumlah MSY, sementara tidak ada penambahan jumlah upaya (unit).

Tingkat pemanfaatan ikan Layang di Prigi tahun 2013 telah mencapai 123\%. Rata-rata tingkat pemanfaatan dari tahun 2006 hingga 2013 adalah sebesar 84 \%, Angka ini telah melampaui jumlah tangkapan yang diperbolehkan pemerinta (JTB) yakni 80\%. Sumberdaya ikan layang di Prigi termasuk dalam kategori fully exploited yaitu sumberdaya ikan sudah dieksploitasi hampir mendekati MSY. Dalam hal ini penambahan upaya penangkapan sudah tidak dianjurkan, karena akan mengancam kelestarian sumberdaya.

\section{Ikan Lemuru}

Ikan lemuru merupakan spesies pelagis terbanyak ketiga yang tertangkap di Perairan Prigi, Tercatat dari tahun 2006 hingga 2013, rata- rata produksi ikan lemuru di Prigi sebanyak 2.292 ton per tahun, dengan jumlah produksi terbanyak pada tahun 2009 yaitu 4.439 ton, dan produksi terendah pada tahun 2011 yaitu sebanyak 1.720 ton. Ikan Lemuru di Prigi tertangkap dengan alat purse seine, payang, gillnet, pukat pantai dan trammel net dengan nilai CPUE tertinggi pada alat tangkap purse seine. Berdasarkan standarisasi alat tangkap purse seiene merupakan alat tangkap standar. CPUE ikan lemuru dari tahun 2006 hingga 2013 berfluktuasi setiap tahunnya yaitu antara 6,96 ton/unit hingga 33,4 ton/unit dengan nilai CPUE rata-rata sebesar 18 ton/unit, Nilai CPUE ikan lemuru di Prigi tahun 2006 hingga 2013 selengkapnya dapat dilihat pada Gambar 5. 


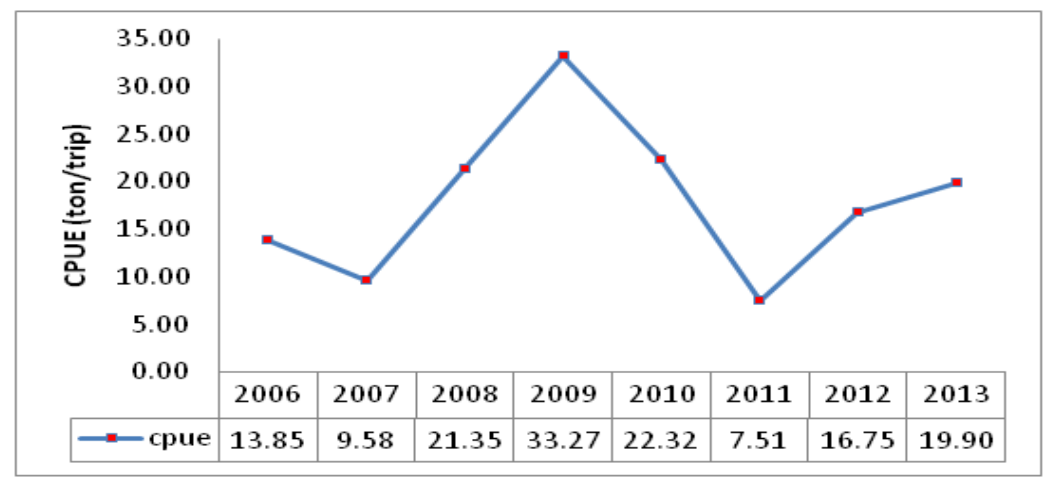

Gambar 5. Fluktuasi Laju Tangkap (CPUE) Ikan Lemuru di Prigi Tahun 2006-2013.

Berdasarkan Gambar 5 terlihat laju tangkap ikan lemuru dari tahun 2006 hingga 2007 mengalami penurunan sebesar $30 \%$, hal ini disebabkan karena penambahan upaya sebesar $25 \%$ yang tidak diikuti dengan penambahan jumlah produksi. Tahun 2008 hingga 2009 CPUE mengalami kenaikan yang cukup tinggi, rata - rata $35 \%$. Hal ini disebabkan karena pengurangan jumlah upaya sebanyak 26\%. Tahun 2010 hingga 2011 nilai jumlah upaya kembali meningkat sebesar rata - rata $35 \%$. Penambahan jumlah upaya yang dilakukan ternyata tidak mempengaruhi pertambahan jumlah produksi. Nilai CPUE menurun tajam di tahun 2010 hingga 2011 yakni rata rata sebesar $14 \%$ per tahun. Tahun 2012 dan 2013 CPUE kembali mengalami peningkatan rata-rata sebesar $33 \%$ yaitu sebesar 19,9 ton. Nilai CPUE rata rata ikan lemuru di Prigi tahun 2006 hingga 2013 berada di bawah CPUE optimum yaitu 26,7 ton.

Hasil analisis regresi linier yang membandingkan antara laju tangkap (CPUE) dan effort (trip) ikan lemuru diperoleh nilai MSY ikan lemuru di Prigi sebesar 3.422 ton dan f optimum sebanyak 127 unit. Grafik MSY selengkapnya dapat dilihat pada Gambar 6.

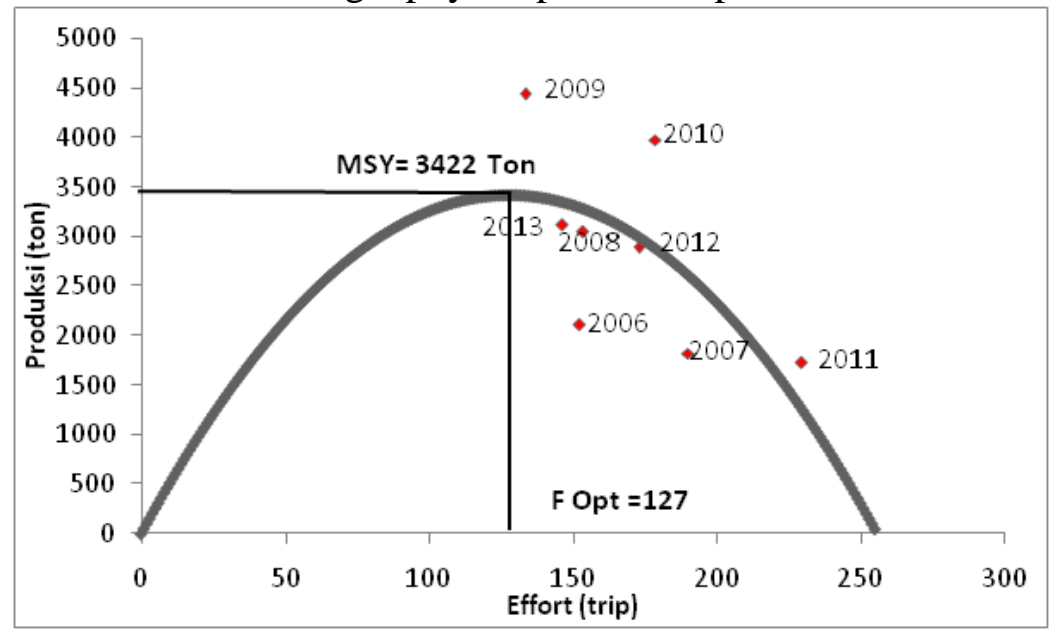

Gambar 6. Grafik MSY Ikan lemuru di Perairan Prigi Tahun 2006 - 2013

Berdasarkan Gambar 6 dapat disimpulkan bahwa produksi rata rata ikan lemuru sepanjang tahun 2006 hingga 2013 berada di bawah MSY kecuali pada tahun 2009 dan 2010 berada di atas MSY, dengan jumlah upaya setiap tahunnya telah melampaui upaya optimum 
yaitu 127 unit. Rata- rata angka tingkat pemanfaatan ikan lemuru di Prigi dari tahun 2006 hingga 2013 sebesar 88\%, melebihi JTB, bahkan pada tahun 2009 telah mencapai 134\% dan menurun di tahun 2010 sebanyak 120\%. Pada tahun 2011 tingkat pemanfaatan menurun tajam hingga 52 $\%$. Upaya penangkapan ikan lemuru di Prigi rata - rata sebesar 169 unit tiap tahunnya telah melampaui nilai f optimum (127). Diduga telah terjadi kejenuhan (over fishing) pada tahun 2009 dan 2010 saat tingkat pemanfaatan telah mencapai $129 \%$ dan penambahan upaya pada tahun 2011 tidak lagi berpengaruh terhadap penambahan jumlah produksi. Penangkapan terhadap sumberdaya ikan lemuru di Prigi telah masuk kategori over exploited, sumberdaya ikan sudah menurun karena ter eksploitasi melebihi MSY. Hal ini sesuai dengan Kepmen NO.45/MEN/2011 tentang estimasi potensi sumberdaya ikan yang menyatakan sumberdaya ikan lemuru telah masuk kategori over exploited pada tahun 2011. Upaya penangkapan harus diturunkan karena kelestarian sumberdaya ikan sudah terganggu.

\section{Ikan Cakalang (Katsuwonus pelamis)}

Ikan cakalang juga merupakan salah satu spesies pelagis besar yang banyak ditemukan di Perairan Prigi. Rata rata produksi ikan cakalang di Prigi dari tahun 2006 hingga 2013 sebanyak 792 ton per tahun. Ikan cakalang di Prigi tertangkap menggunakan pancing tonda, pancing ulur, purse seine, gillnet, dan payang, dengan nilai CPUE tertinggi pada alat pancing tonda, maka alat tangkap standar yang digunakan dalam standarisasi alat tangkap adalah pancing tonda.. Setelah dilakukan standarisasi diketahui CPUE ikan cakalang berkisar antara 5,2 hingga 14,9 ton per tahun. Rata - rata CPUE setiap tahunnya sebanyak 7,3 ton/unit, berada di bawah CPUE optimum yaitu sebanyak 10,96 ton/unit. Nilai CPUE ikan cakalang di Prigi tahun 2006 hingga 2013 selengkapnya dapat dilihat pada Gambar 7.

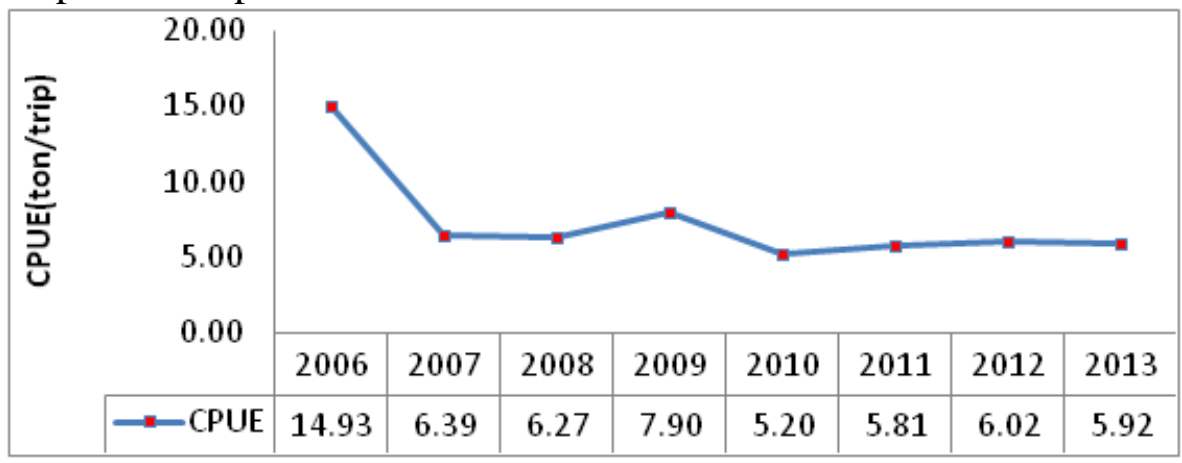

Gambar 7. Fluktuasi Laju Tangkap (CPUE) Ikan Cakalang di Prigi tahun 2006- 2013.

Hasil analisis regresi linier yang membandingkan antara laju tangkap (CPUE) dan effort (trip) ikan cakalang diperoleh nilai MSY sebesar 949 ton dan f optimum sebesar 86 unit Perhitungan nilai MSY dapat dilihat pada Lampiran 6. Berdasarkan Gambar 7 terlihat di tahun 2006 produksi ikan cakalang sangat tinggi hingga melebihi batas MSY dan selanjutnya di tahun 2007 upaya penangkapan ditambah sebanyak 65unit (94\%). Penambahan upaya penangkapan di tahun 2007 hingga melewati f optimum tidak diikuti dengan penambahan produksi. Produksi ikan cakalang di prigi terus menurun hingga 2013 sebanyak 616 ton, bahkan dari tahun 2012 hingga 2013 telah dilakukan pengurangan upaya sebanyak 15 unit (12\%) akan tetapi jumlah produksi masih tetap menurun. Sumberdaya ikan cakalang di Prigi telah memasuki status over exploited yakni stok sumberdaya ikan telah menurun karena tereksploitasi melebihi MSY. 
Komnas Kajiskan pada tahun 2006 telah menetapkan bahwa status pemanfaatan ikan pelagis di Samudera Hindia Selatan Jawa (WPP 573) telah termasuk fully exploited, akan tetapi pada tahun berikutnya masih dilakukan penambahan upaya penangkapan sehingga produksi terus mengalami penurunan dari tahun ke tahun. Upaya penangkapan harus diturunkan karena kelestarian sumberdaya ini sudah terganggu.

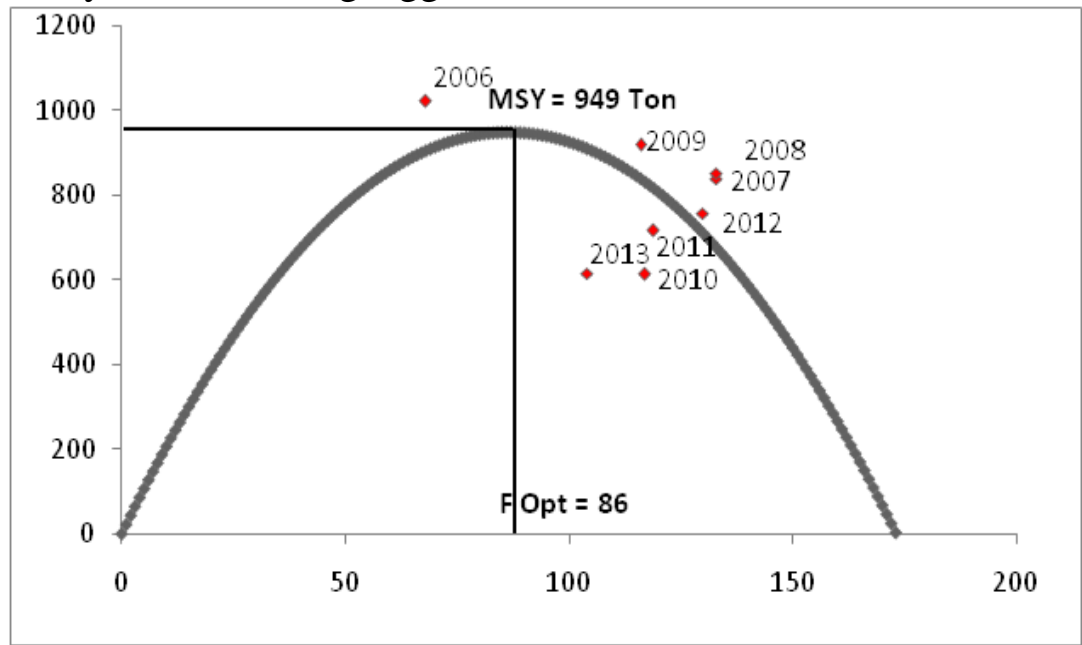

Gambar 8. Grafik MSY Ikan cakalang di Perairan Prigi Tahun 2006 - 2013

Tingkat pemanfaaatan ikan cakalang di Perairan Prigi telah melebihi batas MSY pada tahun 2006 yakni sebesar 108\% dari MSY, dengan tingkat pengupayaan yang belum mencapai f optimum (86 unit). Rata- rata tingkat pemanfaatan ikan cakalang di Prigi telah mencapai $83 \%$, telah melebihi JTB .

Selain empat jenis ikan pelagis diatas masih terdapat empat jenis ikan pelagis yang juga tertangkap setiap tahun di Perairan Prigi yaitu ikan lemadang, tetengkek, slengseng dan bentong, Ikan lemadang yang tertangkap di Prigi paling banyak pada alat tangkap pancing tonda, akan tetapi jumlahnya lebih kecil dibandingkan ikan cakalang, begitu juga pada alat tangkap purse seine, ikan lemadang tertangkap bersamaan dengan tertangkapnya ikan tongkol krai dan layang, di duga ikan lemadang merupakan hasil tangkapan sampingan dari pancing tonda dan purse seine, Ikan tetengkek, slengseng dan bentong tertangkap paling banyak pada alat tangkap pada alat tangkap purse seine bersamaan dengan tertangkapnya ikan lemuru dan layang, ikan tetengkek, slengseng dan bentong merupakan hasil tangkapan sampingan pada alat tangkap purse seine, Nilai potensi lestari (MSY) dari jenis ikan yang merupakan hasil tangkapan sampingan tidak dapat diketahui secara pasti.

Musim Penangkapan

Perhitungan musim penangkapan menggunakan metode rata rata bergerak (moving average) Hasil Analisis indeks musim ikan pelagis dominan di Perairan Prigi disajikan pada Gambar 9. 

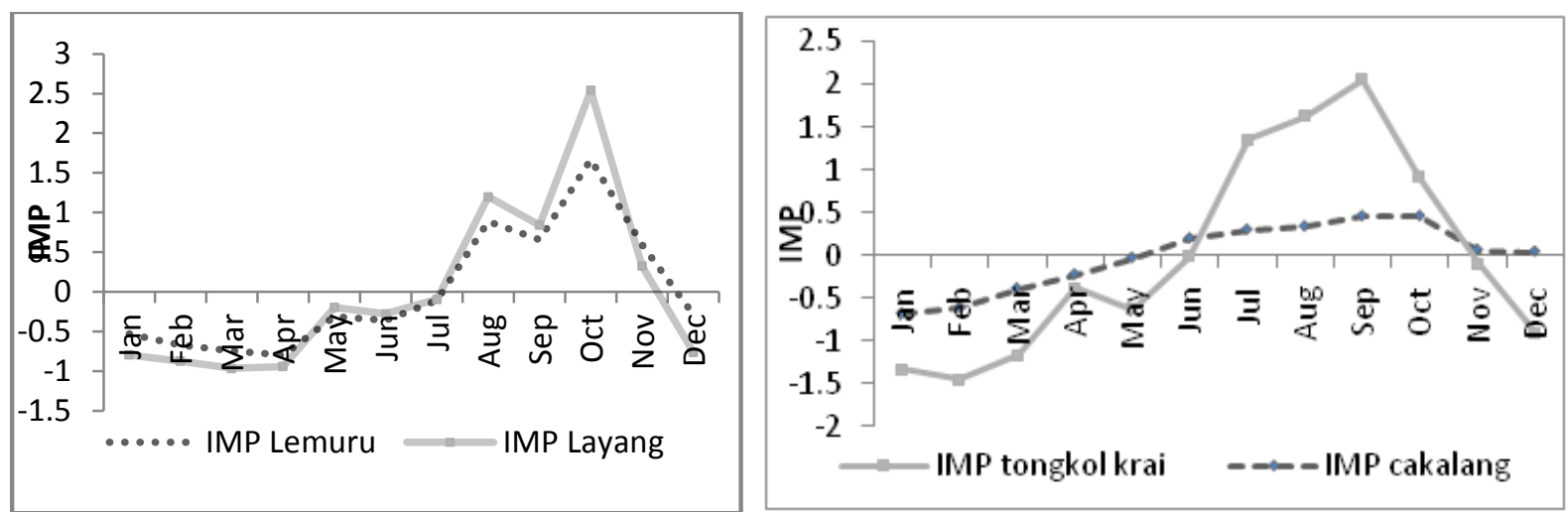

Gambar 9. Indeks Musim Penangkapan Ikan Layang, Lemuru, Tongkol Krai dan Cakalang di

Prigi.

Berdasarkan gambar 9 terlihat bahwa musim ikan lemuru dan ikan layang di Teluk Prigi terjadi bersamaan yaitu dimulai pada bulan Juli hingga November, Musim puncak terjadi pada bulan Agustus dan pada bulan Oktober dimana lokasi penangkapan nelayan Prigi pada saat ini berpusat di dalam Teluk atau cenderung lebih dekat ke daratan (Suwarso 2013). Musim paceklik ikan lemuru dan layang berlangsung dari bulan Desember hingga April. Musim ikan tongkol krai di Perairan Prigi lebih panjang dari pada musim ikan layang dan lemuru, yakni dari bulan April hingga bulan Oktober, sedangkan puncak musim terjadi dua kali selama setahun yakni pada bulan Juli dan September sebulan sebelum musim ikan layang dan lemuru dan berlangsung hingga bulan Oktober, Bulan Desember hingga Maret merupakan musim paceklik ikan Tongkol krai di Prigi.

Musim ikan cakalang di Prigi berlangsung dari bulan Juni hingga Desember dengan modus yang selalu naik semenjak bulan Juni hingga September dan cenderung sama di bulan Oktober, pada bulan November dan Desember yaitu di musim timur hingga musim peralihan II yang mana menurut Suwarso 2013 daerah penangkapan nelayan Prigi saat ini berada di dalam teluk, cenderung lebih dekat dari daratan. Puncak musim penangkapan terjadi pada bulan September dan Oktober, sedangkan musim paceklik ikan cakalang terjadi dari bulan Januari hingga Mei. Balai Riset Perikanan Laut (2004) menyampaikan bahwa musim ikan cakalang dan tongkol di wilayah perairan Selatan Jawa berlangsung antara bulan Juni sampai Oktober dan puncaknya terjadi pada bulan Agustus - September.

Pada dasarnya di musim paceklik pun ikan pelagis masih tertangkap oleh nelayan tetapi dalam jumlah yang sedikit. Menangkap ikan di bulan yang tidak musim hanya akan merugi karena biaya operasional yang dikeluarkan. Pada musim paceklik ini nelayan purse seine Prigi banyak yang masih melaut menggunakan alat tangkap pancing dan jaring gill net, karena biaya yang dikeluarkan relatif lebih ringan. 


\section{KESIMPULAN}

1. Nilai potensi lestari (MSY) ikan tongkol krai di Prigi adalah sebanyak 7,783 ton, ikan layang 4106 ton, ikan lemuru 3304 ton dan ikan cakalang sebanyak 949 ton.

2. Tingkat pemanfaatan ikan tongkol krai di Prigi hingga 2013 telah mencapai 94\%, ikan layang $123 \%$, ikan lemuru yakni $93 \%$ dan ikan cakalang $65 \%$.

3. Musim ikan layang dan lemuru di Prigi berlangsung bersamaan yaitu pada bulan Agustus dan Oktober, musim ikan tongkol krai terjadi pada bulan Juli dan September, sedangkan musim ikan cakalang berlangsung di bulan September hingga Oktober.

\section{DAFTAR PUSTAKA}

Ayodhyoa, A.U. 1981. Metode Penangkapan Ikan. Yayasan Dewi Sri. Bogor 81 Halaman.

Balai Riset Perikanan Laut, 2004 Musim Penangkapan Ikan di Indonesia, Penebar Swadaya . Depok 116 halaman

Gulland JA. 1982. Fish Stock Assesment : A Manual of Basics Methods. FAO/Jhon Willey and Sons. New York.

Harahap I.H. 1987 Penggunaan Model Regresi dalam Ananlisis Data Kelautan. Oseana. 1989 Volume XIV. Nomor 3 hal 101-110.

Keputusan Menteri Kelautan dan Perikanan, 2011 No.45/MEN/2011 tentang Estimasi Potensi Sumberdaya Ikan.

Merta. I.G.S 1993 Hubungan Panjang Berat dan Faktor Kondisi Ikan Lemuru, Sardinella Lemuru Bleeker 1853 dari Perairan Selat Bali, Jurnal Penelitian Perikanan Laut No73 Tahun 1993. BPPL -Jakarta Hal 35-44.

Simbolon. D. 2011 Bioekologi dan Dinamika Daerah Penangkapan Ikan Departemen Pemanfaatan Sumberdaya Perikanan, Fakultas Perikanan dan Ilmu Kelautan Institut Pertanian Bogor.

Sparre, P dan S,C Venema, 1999, Introduction to Tropical Fish Stock Assessment, Part I :Manual FAO. Roma

Suwarso 2013 Prosedur Sampling dan Pengukuran. Penelitian Stok Distribusi dan Parameter Biologi Ikan Pelagis Kecil, Balai Penelitian Perikanan Laut. Jakarta

Suwarso dan Wujdi A. 2013. Exploitation And Catch Fluctuation Of Small Pelagic Fishes In Prigi Waters, Indian Ocean. [Disajikan pada seminar IOPEC 2013] 